明治前期の監獄における規律の導入と展開

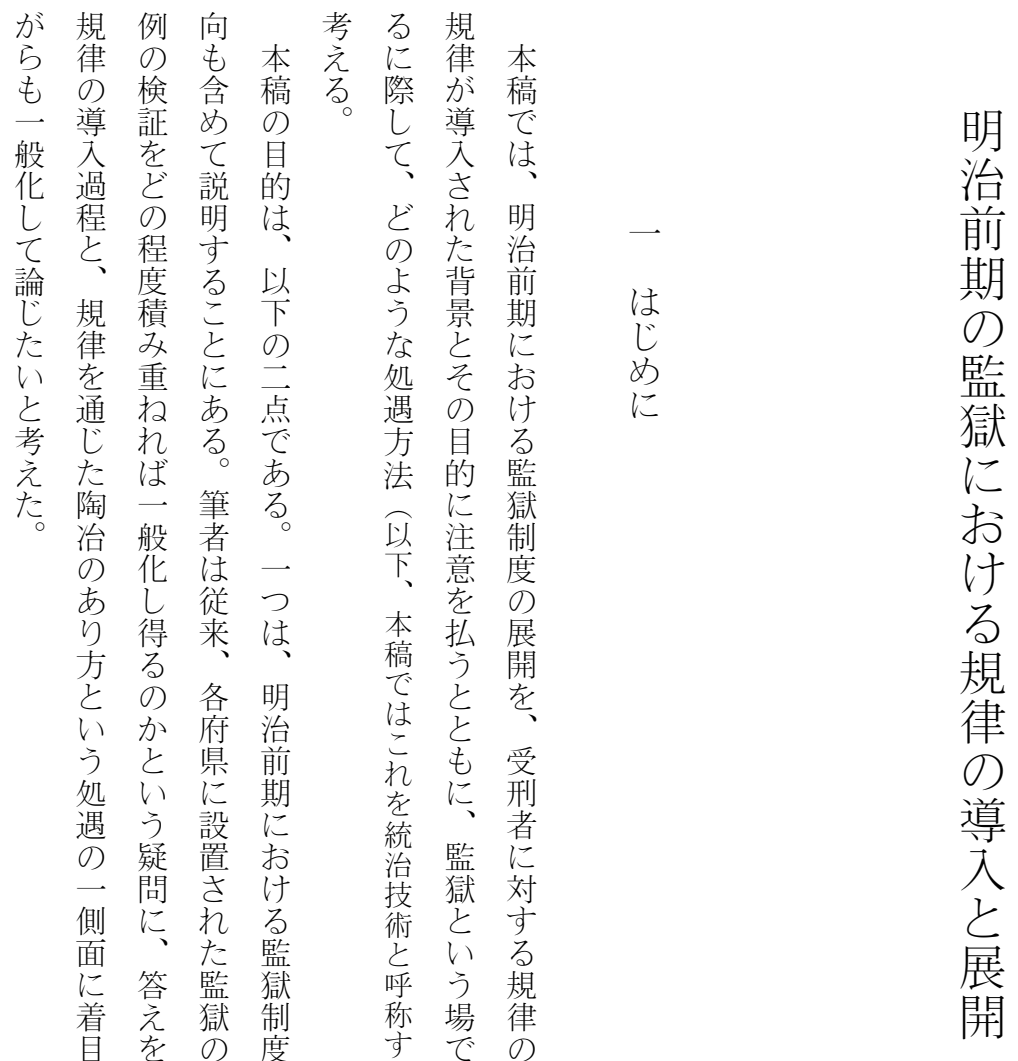

于 出生 の

るせ成展

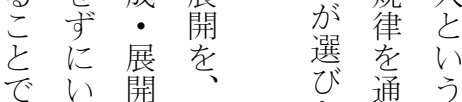

る 過各学観

監。程府 らた点

獄々を県机受㤎

制こ論にた刑ら

度でじ設の者捉

の本てけ かのえ

展稿きら陶た

開にた的把治い

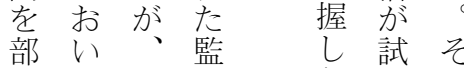

分て個獄たみの

的は別の いら際 
を至のも期い方らてわ国ェしと景型 続とち孝形以る解特れ家儿てどを罰も 制い考乃確で上先き徵て論 度てえん認執の行明づきとつ握らり監一 の第る、し行目研かけたも!守ず扱獄つ 設言た排たさ的究市らと架コるるっへの

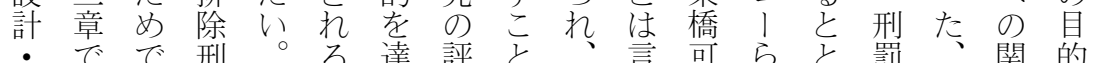

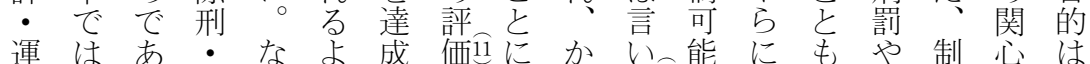

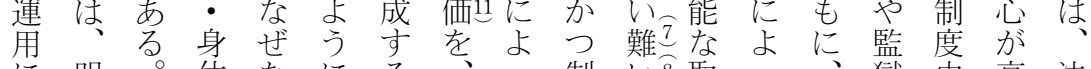

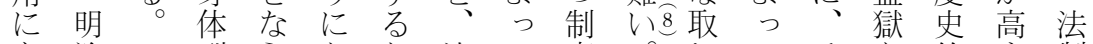
あ治刑らなた法て度。りてそを的ま制 た前に、るめ制存組示の、なり史 る期よ受時、史隣立か及さ分逸考を学 側のつ刑期本学接案るとれ析脱察み の監て者と稿の分・現いたを者がせ法

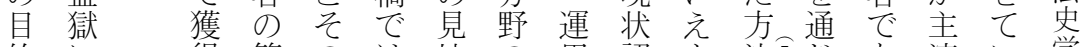
的に得管のは地の用認よ法豆じ流い学 や少理背次か成吉識うをてるでる2

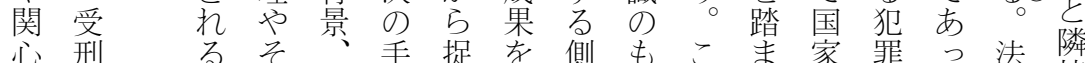

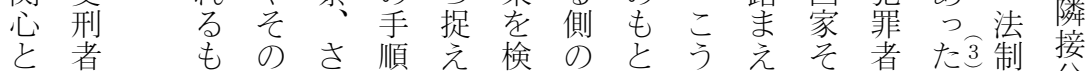
絡をの陶らで直証意心したのをが史分 め管で治に考し守息本たももも秩、学野

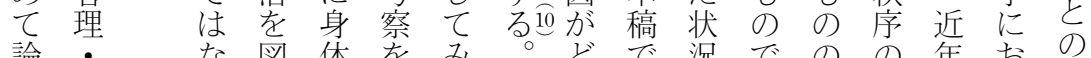

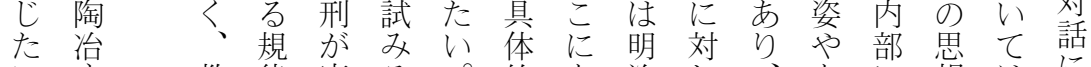
い卞教律廃る。的あ治し、あに想はに る㕕は止。にっ前て同り組史従古 こた刑、をま期、時方みや綟る。 こめ・・学ず

での自般て 次

は様由予自章 特々刑防由に になの省刑运お 規 普目がい 監律交的刑て 獄 や の 統 目治 にと罰は 的技列死 刑 と術こ刑にが しがその位民 七 導導公置衆 受入公開方の 刑ささにけ目 者机机らに のるっつれ見 陶過元るえ 治程もは時な

の の法にを入社

明監制描れ会監近 治を獄史近气る、史獄年、 ○法度学年う方市関史 年制 が側歴しな単係学 代度い㐪てわに夺を 後とから学いち監る中 半そなはにる王国獄各心 にのる、イ 民制法と ”周規十ンそに度令す 監縁律分パれ再ののる 獄にやなク ら編成制隣 “位統対卜の卞立接 が置治話を研る過過分 成守技の与究 立る術試えはスをやに し史にみだ追そお た料よが国ミムうのい とかっ行民シとに背て 
る 八場明治死新

死死多八治政 新卞律本二

刑 刑 ク 恰一府律る而綱 節

のが八モ六は綱

公公死 観 年 当 領

開開 刑 劇に初は

にさ二場出こ死

二机処, 版こ刑

定てセ如され老

のいリクれ占制た

制た 然当茾

約气然、年型斬

毛考而操うに

たう此シ可臬

ら 盗テ刑臬示

しが 此法示を

たえ刑雑述や加

のる。踏義斬え

は

明場会毛染種

五年乗我公

二 テ、其維開明

月 盗現新 前 六

に

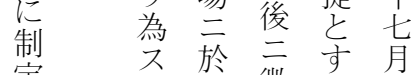

定当篮也徵る

机如䇥ンか、施

た此為二少さ

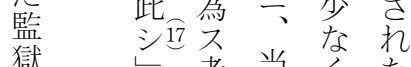

獄則者当々た

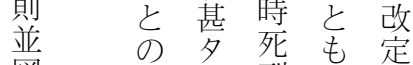

図記多刑黙律

式述力 7 認例

以 が 坚公し も

りナセいれ

リ、シたを

本

稿

な

明

明

治
領で

頒は

唄明

さ治

れ 期

たの

明死

治 刑

至

年 不

を可

境 視

に化

刑さ

種れ

がる

大 過

き 程

< と

変 そ

化 の

ᄂ 背

た 景

様を

子 検

を討

確 寸

認る。

きな

るお

た

め、資

こ以

こ下

は掲

明げ

治る

年 表

以 1

降

をか

対 5

象は
でに
た背が

い景最意

を後識

探にさ

る第 れ

$\begin{array}{llll}\text { の } & \text { 一 } & \text { 四 } \\ \text { 章 時 }\end{array}$

も无期

には

化死

の

不

視

化

自

由

刑

の

普
㠞明气

の年 目

も 代的

と後を

で半 実

そ台守

れ頭る

ました

でため

に懲の

獲 戒 統

得主 治

さ義 技

れと術

た呼が

規ば ど

律れの

やるよ

統 処 う

治遇に

技理 組

術念 み

はを込

活取ま

用りれ

ᄂ上た

得げか

た て と

かこう

否れ点

かがに

を求着

考め自

え 5 守

てれる。 
【表 1】各府県の刑種と自由刑の割合

\begin{tabular}{|c|c|c|c|c|c|c|c|c|c|c|c|c|c|c|c|c|c|c|c|c|c|c|c|c|c|c|}
\hline 長崎県 & 臬示 & $\begin{array}{l}\text { 引廻 } \\
\text { 死罪 }\end{array}$ & 斬 & 絞 & 流罪 & 准流 & $\begin{array}{l}\text { 終身 } \\
\text { 娒役 }\end{array}$ & $\begin{array}{l}\text { 懲役 } \\
1 \text { 年- }\end{array}$ & $\begin{array}{l}\text { 懲役 } \\
-1 \text { 年 }\end{array}$ & 徒刑 & \begin{tabular}{|l} 
重敲 \\
\end{tabular} & $\begin{array}{l}\text { 敲 } \\
\text { 徒刑 }\end{array}$ & 杖 & 答 & $\mid \begin{array}{l}\text { 入墨 } \\
\text { 重敲 }\end{array}$ & \begin{tabular}{|l|} 
入墨 \\
敲
\end{tabular} & 嶶溜 & 入墨 & 重敲 & 敲 & 押込 & 手鎖 & $\begin{array}{l}\text { 牢内 } \\
\text { 手鎖 }\end{array}$ & $\begin{array}{l}\text { 過急 } \\
\text { 完 }\end{array}$ & $\begin{array}{l}\text { 終身 } \\
\text { 鎖銅 }\end{array}$ & 鎖銅 \\
\hline 明治 2 年 & & 3 & 1 & & & & & & & 18 & 1 & 22 & & & 19 & 13 & 6 & 5 & 5 & 9 & 3 & 3 & & & & \\
\hline 明治 3 年 & & & & & & & & & & 20 & & & & & 18 & 18 & 16 & 2 & 16 & 40 & 19 & & 3 & 3 & & \\
\hline 明治 4 年 & & & 3 & 5 & 9 & 18 & & & & 15 & & & 107 & 43 & & & & & & & & & & & & \\
\hline 明治 5 年 & & & 1 & 4 & & 4 & & & 83 & 16 & & & 31 & 19 & & & & & & & & & & & & \\
\hline 明治 6 年 & 2 & & 3 & 1 & & 14 & 4 & 4 & 4295 & 10 & & & 18 & 78 & & & & & & & & & & & 1 & \\
\hline 明治 7 年 & & & 2 & & & & 11 & 22 & 575 & & & & 4 & 21 & & & & & & & & & & & & \\
\hline 明治 8 年 & & & 1 & 3 & & & 5 & 13 & \begin{tabular}{l|l}
399 \\
\end{tabular} & 1 & & & 5 & & & & & & & & & & & & & \\
\hline 明治 9 年 & & & & & & & 10 & 37 & \begin{tabular}{|l|l|}
7330 \\
\end{tabular} & & & & & & & & & & & & & & & & & 1 \\
\hline 明治 10 年 & & & 1 & & & & 7 & 31 & 1265 & & & & & & & & & & & & & & & & & \\
\hline 明治11年 & & & 2 & & & & 15 & 37 & \begin{tabular}{l|l}
7245 \\
\end{tabular} & & & & & & & & & & & & & & & & & \\
\hline
\end{tabular}

\begin{tabular}{|c|c|c|c|c|c|c|c|c|c|c|c|c|c|c|c|c|c|}
\hline 長崎県 & 禁獄 & 譁慎| & 閉門 & 除族 & 禁䤧 & 加役 & 棒鎮 & 収賏| & 顛罪 & \begin{tabular}{|l|} 
罚金 \\
\end{tabular} & $\begin{array}{l}\text { 過料 } \\
\text { 科料 }\end{array}$ & 償金 & 可責 & 叱 & 合計 & $\begin{array}{l}\text { 自由 } \\
\text { 刑 }\end{array}$ & \begin{tabular}{|l|} 
自由那 \\
割合
\end{tabular} \\
\hline 明治 2 年 & & & & & & & & & & & 2743 & & & 29 & 2880 & 41 & $1.4 \%$ \\
\hline 明治 3 年 & & & & & 2 & & & & & & 58 & & 78 & & 293 & 20 & $6.8 \%$ \\
\hline 明治 4 年 & 20 & 16 & & & & & & 22 & 12 & & & & 64 & & 338 & 42 & $12.4 \%$ \\
\hline 明治 5 年 & 4 & 2 & 1 & & & & & 5 & 31 & & & & & 22 & 223 & 103 & $46.2 \%$ \\
\hline 明治 6 年 & 2 & 13 & 8 & 15 & 4 & & & 52 & 97 & & & & 59 & & 680 & 327 & $48.1 \%$ \\
\hline 明治 7 年 & 10 & & & 1 & 5 & & 3 & 13 & \begin{tabular}{|l|}
999 \\
\end{tabular} & & 17 & & 37 & 21 & 1741 & 608 & $34.9 \%$ \\
\hline 明治 8 年 & 8 & & & 1 & & 1 & 2 & 69 & 1395 & 13 & 47 & 1 & 35 & 18 & 2017 & 418 & $20.7 \%$ \\
\hline 明治 9 年 & 6 & & & 5 & & & 2 & 63 & 416 & 2 & 49 & & 177 & & 1098 & 377 & $34.3 \%$ \\
\hline 明治10年 & 8 & & & 11 & & & 4 & 37 & 117 & 19 & 45 & 4 & & 15 & 564 & 303 & $53.7 \%$ \\
\hline 明治11年 & 6 & & & 1 & & & 2 & 41 & 55 & 65 & 64 & 1 & & 9 & 543 & 297 & $54.7 \%$ \\
\hline
\end{tabular}

※「自由刑」に含めたのは、太線で囲んだ「流罪」から「敲徒刑」までの部分。

※明治 6 年「懲役 1 年以下」のセルは、 2 か所に分けて記されている件数を合計したもの。

出典：国立公文書館所蔵『長崎県史料 五 刑賞』、『長崎県史料 十六 刑罰條』

\begin{tabular}{|c|c|c|c|c|c|c|c|c|c|c|c|c|c|c|c|c|c|c|c|c|c|c|c|c|c|c|}
\hline 山口県 & 香示 & 斬 & 絞 & \begin{tabular}{|l} 
准流 \\
徒役 \\
\end{tabular} & & 缺役 & 管 & 杖 & 禁錮 & |閉門 & 謹槙 & 禁獄 & 鎖銅 & |閏刑 & 除族 & 頑罪 & 收䫏 & 罰金 & 棒鎖 & 暗室 & 拘役 & 呵責 & $\begin{array}{l}\text { 犯罰 } \\
\text { 則 }\end{array}$ & 合計 & $\begin{array}{l}\text { 自由 } \\
\text { 刑 }\end{array}$ & \begin{tabular}{|c|}
$\mid$ 自由利 \\
割合
\end{tabular} \\
\hline 明治 5 年 & 2 & 11 & 5 & 21 & 23 & & 220 & 243 & 1 & 11 & 26 & 10 & & & & 267 & 48 & & & & & & & 888 & 44 & $5.0 \%$ \\
\hline 明治 6 年 & & & & & & 772 & & & & & & 16 & 2 & 56 & 27 & 218 & 132 & & & & & 404 & & 1627 & 772 & $47.4 \%$ \\
\hline 明治 7 年 & & 3 & 2 & & & 1021 & & & & & & 31 & 2 & 21 & 24 & 203 & 152 & 50 & & & & 78 & & 1587 & 1021 & $64.3 \%$ \\
\hline 明治 8 年 & & 5 & 1 & & & 552 & 350 & 1 & & & & 17 & 2 & 28 & 23 & 374 & 106 & & & & & 73 & \begin{tabular}{|l|l|}
319 \\
\end{tabular} & 1531 & 552 & $36.1 \%$ \\
\hline 明治 9 年 & 1 & 6 & 2 & & & 456 & 178 & 1 & & & & 3 & & 15 & 4 & 466 & 136 & & & & & 97 & 72 & 1364 & 456 & $33.4 \%$ \\
\hline 明治10年 & & 1 & & & & 749 & & 15 & & & & 17 & & & 17 & 223 & \begin{tabular}{|l|l|} 
& 136 \\
\end{tabular} & & 2 & 1 & & 41 & & 1202 & 749 & $62.3 \%$ \\
\hline 明治11年 & 1 & & & & & 956 & & & & & & 17 & 3 & & 15 & 219 & 177 & & 1 & & 1 & 41 & 1090 & 1431 & 956 & $66.8 \%$ \\
\hline 明治12年 & & 3 & & & & 1005 & & 1 & & & & 12 & 1 & & 6 & 253 & \begin{tabular}{|l|}
146 \\
\end{tabular} & & 12 & & & 49 & 627 & 7488 & 1005 & $67.5 \%$ \\
\hline 明治13年 & & 1 & & & & 1091 & & & & & & 28 & & & 3 & 264 & 193 & & 15 & & & 132 & 1020 & 1727 & 1091 & $63.2 \%$ \\
\hline 明治14年 & & & & & & 977 & & 1 & 16 & & & 17 & 1 & & 11 & 186 & 195 & & 23 & & 1 & 15 & 1229 & 1443 & \begin{tabular}{|l|l|}
3 & 977 \\
\end{tabular} & $67.7 \%$ \\
\hline
\end{tabular}

※網掛け部分の「犯罰則」については、処刑数の合計に含めていない。

※「自由刑」に含んだのは、太線で囲んだ「准流・徒役」から「懲役」までの部分。

出典 : 山口県文書館編『府県史料 山口県 二』 


\begin{tabular}{|c|c|c|c|c|c|c|c|c|c|c|c|c|c|c|c|c|c|c|c|c|c|c|c|c|c|c|}
\hline 京都府 & 则 & $\begin{array}{l}\text { 臬首 } \\
\text { 香示 }\end{array}$ & 斬 & 死罪 & 絞 & 自裁 & 流 & 准流 & 徒 & 懲役 & 敲 & 杖 & 答 & 禁獄 & 禁銅 & 除族 & $\begin{array}{l}\text { 除族 } \\
\text { 收賏 }\end{array}$ & 閉門 & 鎖錭 & 棒鎮 & 閭室 & 謹慎 & 手鎖 & 押込 & 贖罪 & 収瞋 \\
\hline 明治 1 年 & 11 & 5 & & 1 & & & 1 & & 46 & & 157 & & & & 8 & & & 3 & & & & 16 & 72 & 31 & & \\
\hline 明治 2 年 & 9 & 4 & 1 & & & & 5 & & 148 & & 243 & & & & 30 & & & 21 & & & & 11 & 76 & 42 & & \\
\hline 明治 3 年 & 1 & 6 & 2 & & & & 8 & & 223 & & 382 & & & & 5 & & & 57 & & & & 41 & 186 & \begin{tabular}{|l|l|}
5 & 128 \\
\end{tabular} & & \\
\hline 明治 4 年 & & 1 & 8 & & & & 10 & & 33 & & & 552 & 288 & 23 & 3 & & & 6 & & & & 62 & & & 87 & 80 \\
\hline 明治 5 年 & & 1 & 6 & & 2 & 1 & & 119 & 98 & 872 & & 208 & 68 & 19 & 8 & & & 28 & & & & 83 & & & 353 & \begin{tabular}{|l|l|}
3 & 139 \\
\end{tabular} \\
\hline 明治 6 年 & & 1 & 20 & & 5 & & & & 22 & 760 & & & & 1 & 19 & & & 6 & & 2 & 2 & 18 & & & 576 & $\begin{array}{ll}5 & 173 \\
\end{array}$ \\
\hline 明治 7 年 & & 1 & 5 & & 2 & & & & & \begin{tabular}{|l|}
589 \\
\end{tabular} & & & & 21 & 26 & 3 & 1 & & & 13 & 5 & & & & 365 & \begin{tabular}{|l|l|}
5 & 102 \\
\end{tabular} \\
\hline 明治 8年 & & 1 & 24 & & 2 & & & & & \begin{tabular}{|l|}
991 \\
\end{tabular} & & & & 29 & & 9 & & & 2 & 2 & & & & & 1878 & \begin{tabular}{|l|l|}
3257 \\
\end{tabular} \\
\hline 明治 9 年 & & & 11 & & 1 & & & & & 1288 & & & & 20 & & & & & & 4 & & & & & 2042 & 272 \\
\hline 明治10年 & & & 6 & & & & & & & 1143 & & & & 35 & & & & & & 1 & & & & & 452 & 159 \\
\hline 明治11年 & & & 3 & & & & & & & 2699 & & & & 1 & & & & & & & & & & & \begin{tabular}{|l|}
595 \\
\end{tabular} & 5 \\
\hline
\end{tabular}

\begin{tabular}{|c|c|c|c|c|}
\hline 京都府 & 科料 & 合計 & $\begin{array}{l}\text { 自由 } \\
\text { 刑 }\end{array}$ & \begin{tabular}{|l|} 
自由利 \\
割合
\end{tabular} \\
\hline 明治 1 年 & & 351 & 47 & $13.4 \%$ \\
\hline 明治 2 年 & & 590 & 153 & $25.9 \%$ \\
\hline 明治 3 年 & & 1039 & 231 & $22.2 \%$ \\
\hline 明治 4 年 & & 1153 & 43 & $3.7 \%$ \\
\hline 明治 5 年 & & 2005 & 1089 & $54.3 \%$ \\
\hline 明治 6 年 & & 1606 & \begin{tabular}{|l|}
782 \\
\end{tabular} & $48.7 \%$ \\
\hline 明治 7 年 & 3 & 1184 & 589 & $49.7 \%$ \\
\hline 明治 8 年 & 14 & 3250 & 991 & $30.5 \%$ \\
\hline 明治 9 年 & 77 & 3796 & 1288 & $33.9 \%$ \\
\hline 明治10年 & 152 & 2645 & 1143 & $43.2 \%$ \\
\hline 明治11年 & & 8826 & 2699 & $30.6 \%$ \\
\hline
\end{tabular}

※「自由刑」に含めたのは、太線で囲んだ「徒」から「懲役」までの部分。

出典 : 京都府総合資料館所蔵『京都府史 政治部 刑賞 刑類』

\begin{tabular}{|c|c|c|c|c|c|c|c|c|c|c|c|c|c|c|c|c|c|c|c|c|c|c|}
\hline 岐阜県 & 臬 & 斬 & 絞 & 准流 & 徒 & 懲役 & 杖 & 答 & $\begin{array}{l}\text { 買罪 } \\
\text { 買 }\end{array}$ & \begin{tabular}{|l|} 
轒罪 \\
\end{tabular} & |収瞔|| & 閏刑|諺 & 除族 & 禁獄 & 鎖錭 & 棒鎖 & 呵責 & $\begin{array}{c}\text { 犯罰 } \\
\text { 則 }\end{array}$ & 減免 & 合計 & $\begin{array}{l}\text { 自由 } \\
\text { 刑 }\end{array}$ & $\begin{array}{l}\text { 自由帅 } \\
\text { 割合 }\end{array}$ \\
\hline 明治 4 年 & & & 1 & 3 & 3 & & 32 & 14 & 6 & & & 1 & & & & & & & & 60 & & \begin{tabular}{|l|l|}
$510.0 \%$ \\
\end{tabular} \\
\hline 明治 5 年 & 1 & 13 & 2 & 13 & 31 & & 651 & 282 & 89 & & & 25 & 16 & 21 & & & & & & 1144 & 44 & \begin{tabular}{|l|l|}
$4.8 \%$ \\
\end{tabular} \\
\hline 明治 6 年 & & 7 & 8 & 16 & & 1146 & 189 & 11 & 89 & 132 & 28 & 15 & 5 & 6 & & 1 & & & & 1657 & 1166 & $570.4 \%$ \\
\hline 明治 7 年 & & 2 & 2 & & & 1181 & & & & \begin{tabular}{|l|}
338 \\
\end{tabular} & 91 & & 7 & 6 & & 6 & & & & 1197 & 745 & $562.2 \%$ \\
\hline 明治 8 年 & & & & & & 1226 & & & & 618 & 105 & 5 & & & & & 19 & \begin{tabular}{|l|}
281 \\
\end{tabular} & 178 & 1245 & 498 & $40.0 \%$ \\
\hline 明治 9 年 & & 13 & & & & 1090 & & & & 560 & 136 & 7 & & & & & & 1039 & 218 & 1142 & 387 & $73.9 \%$ \\
\hline 明治10年 & & 2 & & & & 1798 & & & & 657 & \begin{tabular}{|l|}
241 \\
\end{tabular} & 8 & 5 & & & & 409 & \begin{tabular}{|l|}
928 \\
\end{tabular} & 290 & 2209 & 887 & $740.2 \%$ \\
\hline 明治11年 & & 1 & 1 & & & 2580 & & & & 618 & 255 & 12 & 2 & & 4 & t. & & 1645 & 221 & 2656 & 1693 & $363.7 \%$ \\
\hline 明治12年 & & 2 & & & & 1851 & & & & 318 & 234 & & 5 & & 1 & it & & 1634 & 132 & 1889 & 1294 & $468.5 \%$ \\
\hline
\end{tabular}

※明治 7 年以降、贖罪・収贖・閏刑・除族は本刑にも内数としてカウントされているため、「合計」・「自由 刑」を算出する際に重複を避けた。

※網掛け部分の「犯罰則」「減免」については、処刑数の合計に含めていない。

※「自由刑」に含んだのは、太線で囲んだ「准流」から「嶶役」までの部分。

出典：公文書館所蔵『岐阜県史稿 政治部一、二』

\begin{tabular}{|c|c|c|c|c|c|c|c|c|c|c|c|c|c|c|c|c|c|c|c|c|}
\hline 埼玉県 & 臬首 & 斬 & 絞 & 流 & 徒 & 懲役 & 杖 & 笞 & 収睸 & 償罪 & 叱 & 除族 & \begin{tabular}{|l} 
责付 \\
閏刑 \\
禁獄
\end{tabular} & 放免 & \begin{tabular}{|} 
違警 \\
罪
\end{tabular} & 売淫 & 合計 & $\begin{array}{l}\text { 自由 } \\
\text { 刑 }\end{array}$ & $\mid \begin{array}{l}\text { 自由利 } \\
\text { 割合 }\end{array}$ & 備考 \\
\hline 明治 4,5 年 & & 23 & 4 & 23 & 36 & & 395 & 237 & 17 & 37 & & & & & & & 772 & 59 & $7.6 \%$ & M4. 12. 24-M5. 8.17 \\
\hline 明治 5 年 & & 16 & 3 & 12 & 16 & 128 & 10 & & & & 61 & 1 & & & & & 247 & 156 & $63.2 \%$ & M5. 8埼玉裁判所開設以降 \\
\hline 明治 6 年 & & 22 & 4 & & & 812 & & & & & & & & & & & 838 & 812 & $96.9 \%$ & \\
\hline 明治 7 年 & 1 & 29 & 2 & & & 739 & & & & & & & & & & & 771 & 739 & $95.8 \%$ & \\
\hline 明治 8 年 & & 16 & & & & 506 & & & 141 & 492 & & 2 & & & & & 1157 & 506 & $43.7 \%$ & \\
\hline 明治 9 年 & & 14 & 1 & & & 966 & & & 136 & 399 & & 3 & & & 13 & 31 & 1519 & 966 & $63.6 \%$ & \\
\hline 明治10年 & & 4 & 3 & & & 1007 & 1489 & 1 & 50 & 62 & & 3 & 28 & 384 & 144 & 16 & 2646 & 1007 & $38.1 \%$ & 国事犯97人を懲役に含む \\
\hline 明治11年 & 1 & 4 & 1 & & & 1663 & 1248 & 7 & 81 & $\mid 108$ & & & & 301 & 207 & 38 & 3106 & 1663 & $53.5 \%$ & \\
\hline 明治 12 年 & & 9 & 1 & & & 2803 & & & 75 & 155 & & & 15 & 402 & 148 & 30 & 3058 & 2803 & $91.7 \%$ & \\
\hline 明治13年 & & 5 & 2 & & & 2255 & & & & & & & 3 & & 63 & 76 & 2265 & 2255 & $99.6 \%$ & \\
\hline 明治14年 & & 4 & & & & 2255 & & & & & & & & & 82 & 369 & 2259 & 2255 & $99.8 \%$ & \\
\hline
\end{tabular}

※明治 4 年の閏刑、贖罪、収贖は、内数表示 (その他の年も同様の扱いがなされている可能性がある)。

※網掛け部分の「放免」「違警罪」「売滛」については、処刑数の合計に含めていない。

※「自由刑」に含んだのは、太線で囲んだ「流」から「懲役」までの部分。

出典 : 国立公文書館所蔵『埼玉県史料五〜九 政治部刑罰』 
二然社臬治成る ま 存制法の た佥けた年 酸爷会示然的忘をいをの場同者と獄 鼻 云 セ路害儿年とめ却定明聞箇設に斬よ省

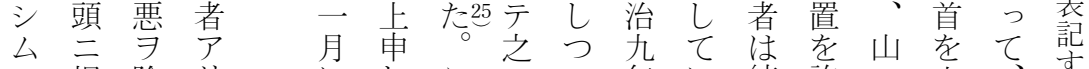

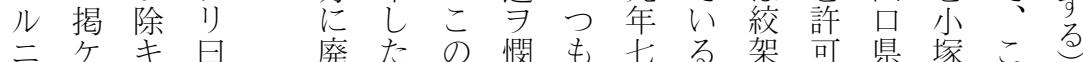

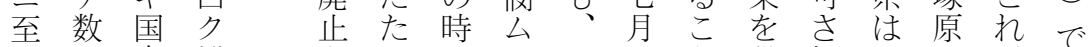

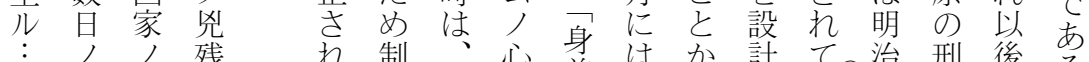

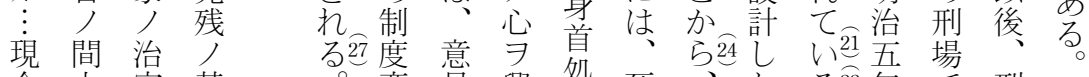
今学安甚 法衆保 キ 改 三 持 者 正示 ノシル待 挙 其 “ 乃惨於所 レ 状テ以 八 観 既 ナ 如ル三リ 此二足卜 キ忍儿夫 , 归 酷 少卜兇 刑儿天残 八 7 亦, 他以何甚 日广y シ 必今学者 廃㴪臬 此示雖 也其窟卜 ラ罪示毛 儿驾醌学 三 28 壂 年 而儿ル 言卟死

其 $\exists$ 刑 刑為 7 破学以

酷中示

t

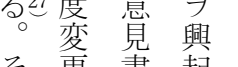

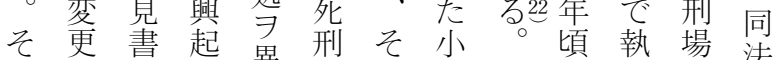
の纪是也異執の原明行羿法 契注覃三三行過重治旧し監か 機い案台鮮方程哉吾来て獄刑

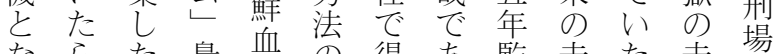
ならた臬血の得あ監未た未筫

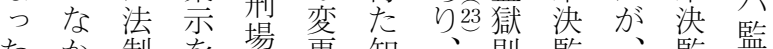
た加制老場更知、則監、監擥

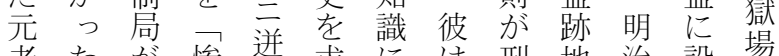
茬たが惨迸求泥注刑地治設場

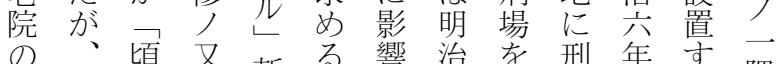

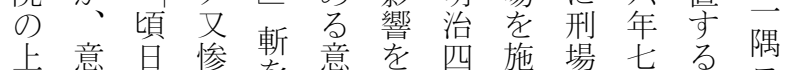

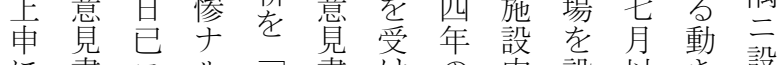
飞書云儿酷書付の㖞設以气設

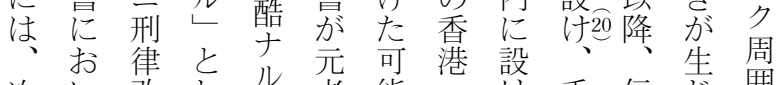

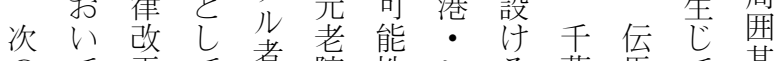
のて正者院性三る葉馬て其

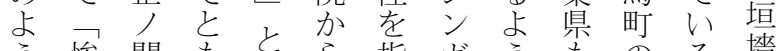

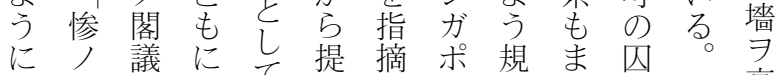

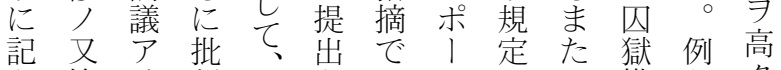
さ渗り判コさき儿し明構えク

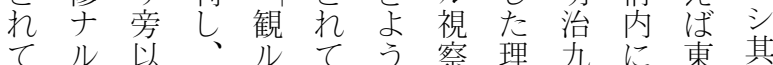

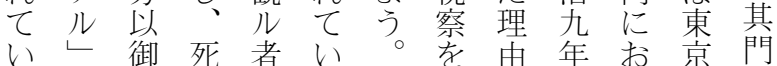

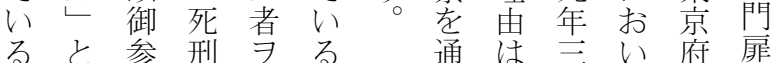

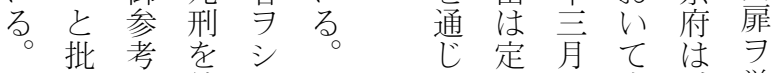

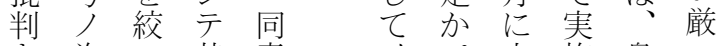

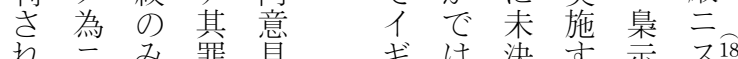

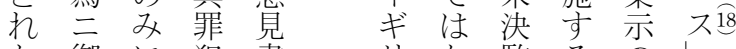
た御に犯書りな監るす 集留二石㩤己宣と 系置本憎死のが地と告規

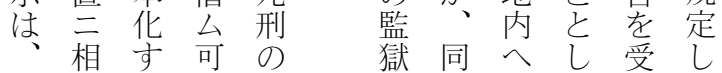


明治前期の監獄における規律の導入と展開

【表 2】明治 $8-14$ 年の死刑執行件数

\begin{tabular}{|l|r|r|r|}
\hline & 絞 & 斬 & 臬 \\
\hline 明治 8 年 & 68 & 371 & 13 \\
\hline 明治 9 年 & 30 & 341 & 7 \\
\hline 明治10年 & 24 & 101 & 10 \\
\hline 明治11年 & 18 & 131 & 20 \\
\hline 明治12年 & 19 & 135 & - \\
\hline 明治13年 & 6 & 119 & - \\
\hline 明治14年 & 3 & 93 & \\
\hline
\end{tabular}

出典 :『刑事綜計表』・『司法省刑事統計年報』

※『司法省第七刑事統計年報』（明治14年）には、「臬」の闌が存在しない。

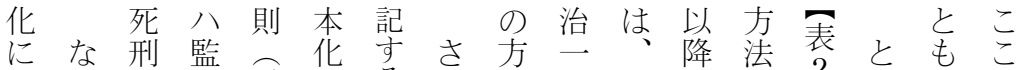

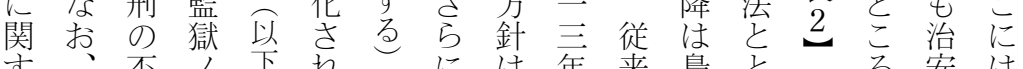

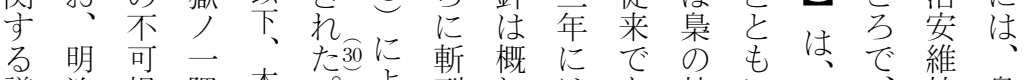
議治視隅本稿よ刑权はあ執に明、持臬 論一化三稿旧つ毛遵斬れ行示治臬の招 に○は設ば刑て、守刑ば件し治示目の は年明ケ明法廃明さが菒数た年が的残 代治墻治の步治れ宣示がも年廃は虐 西 前一壁 治施さ 一た 告が○のの步達性 洋半五 $习$ 四行れ主も適にで 法に年以年を、年の礼用なあ同れでそ の にテ監前こにとてさっる。四たきの 導ら達外獄 提れ公みいれて。四のる 弊 入机成見則と市と砵てい一年ち、と害 をるさ 闵臬机防表て、れいした。方かて主の る示たク記明死たでたっ具れけす張言 政おこへす治刑刑あが謀体ばて方を及

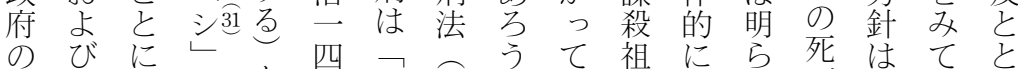
のびに斬なと罗獄、う。て 祖にら死はて と

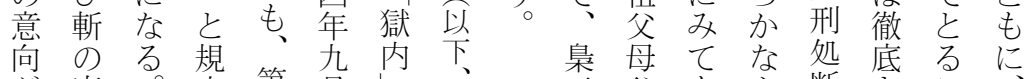

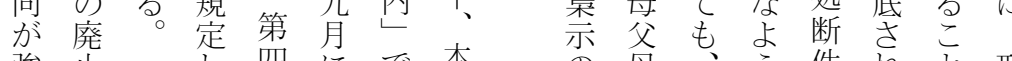
強止し四にで本京再、う件れと刑 之と 一制の稿て廃し例に数たがの

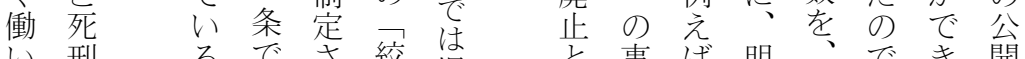
い刑るでさ絞旧省事ば明、でき開

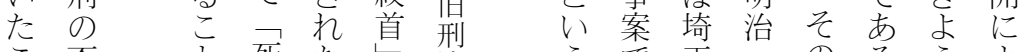

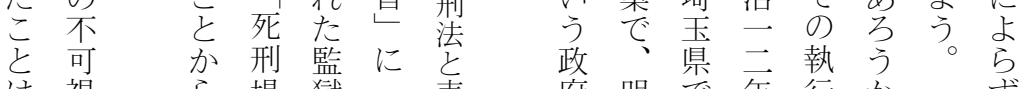
は視 ら、場獄 一表 府明集年行か。 


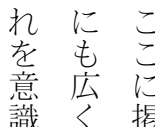

識取揭

る y 5

人入れ

々れた

に 5 説

よれ 明

っては

て

進る告先

め。に

万衣少

れうた

もた老

の 状 院

考況审

え 50

て

ょて容

でや毛

あは共

ろり通

う。死点

刑 が

のあ

不り

視ま

化 た

は旧

刑

西 法

洋 の

法 施

の 行

知 後

見に

に出

由 版

来さ

ᄂ れ

、た

か 注

橎
ア 笑二見之

ルテ淢不虚

至衆或儿感死

于

八シ雹八フ引

甚テ基 シ 用

夕感甚昌随者

刑激 公注

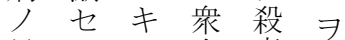

貝云人意公

的入至, 至

习文群生二

失八衆 示

フ愛刑スル シ

卜粼人ル二言

云, 上考方分

へ葙場残 其

シ 35 起 严 息苛

シ下儿極刻

メア力

ン 年年見

至甚至 馴

ヨルシ ル 馴

務其 キ コル

テ醜公幼卢

刑刑童儿キ

习場

以 携 三 其

于見入是心

却儿ル其自

テヨ者危

誉号害垔

モモリナ

甚其 少

得空卜

ルキ多不

ココ行儿恐

ト卢三所

リリ当り残

如又当決忍

此刑

キ 場 或 $\exists$ 有

コ公公様
ナ 議刑は想

ド論不各像

がお可国難

死 い視 刑 <

刑て 化法な

のも老产

不予を

可ボ定参 例

視アし 照え

をナいた明

訴 る

えドょで公

たは理死た死年

由 刑刑

はの旧公

次全刑斬

の的の 早

記な草と本

要視あ 市刑

約化たつ初

さをる辛刑案

よ翢晨本行の

う。登本行 の

鶴 法事篡

田案獄階

も采獄

ま作合お

た成於い

こ段 テて

れ階 不

を受の゙ル刑

け鶴卜法

入田論草

れと案

てボ待取

いア多調

る34 ソ ス 掛

$\begin{array}{llll}\text { ボ } & \text { と } & \text { 官 } \\ \text { ア ド } & \text { 官 }\end{array}$

ソの死 
明治前期の監獄における規律の導入と展開

【グラフ】各府県の処断件数に占める自由刑の割合

$120.0 \%$
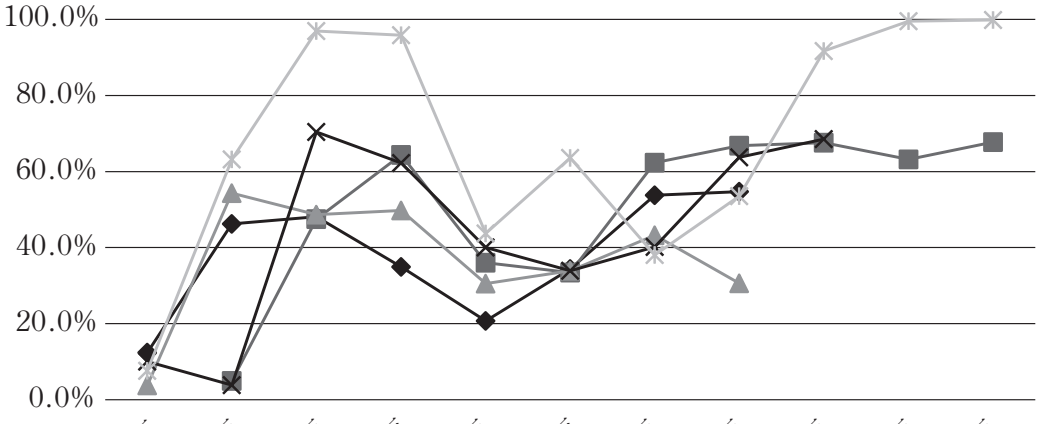

and

依次

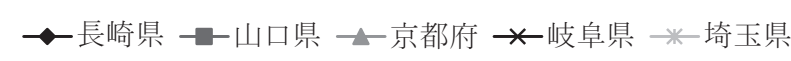

ま徒し従びけい五る。近る 傾刑 この

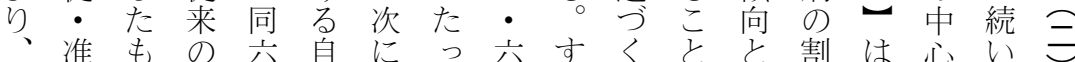

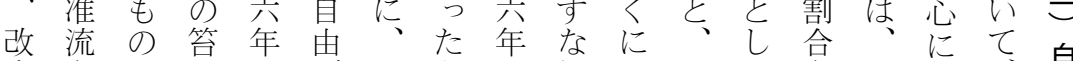

定建懲あ゙杖月

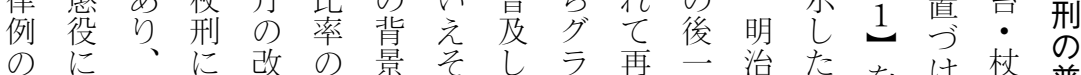

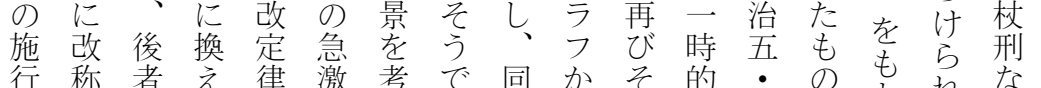

行称者え 律 激考で同かそ的・六てをれれ

にしでて 例な え

りさこれ施び み

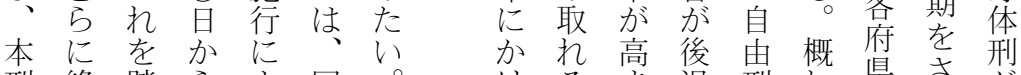

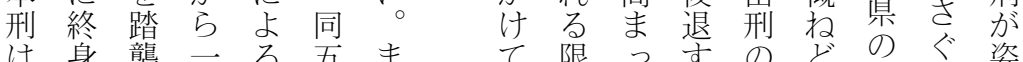

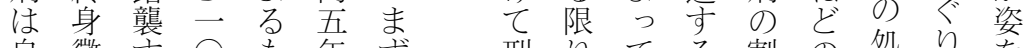

自懲守 $\bigcirc$ も年ず刑りてるる割の 処り

由役る○の四、罰でゆこ合府断た消

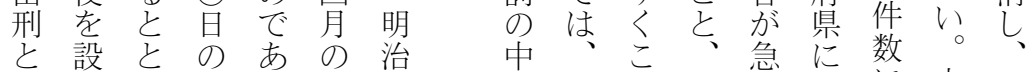

死沙も懲 懲五治心自亡 明急に激に上自

刑てに役う役・省由治にあ占揭由

の い、刑。法38六占刑確—伸てめの刑

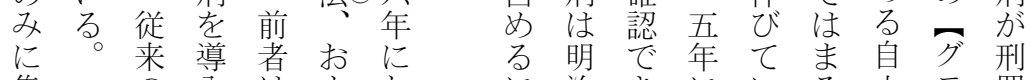

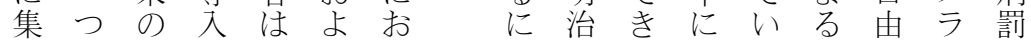


【表 3】新刑法実施前後在監人比較表（抜粋）

\begin{tabular}{|c|c|c|c|}
\hline 年 & 未決者 & 已決囚 & 笞杖 \\
\hline 自明治 8 年 7 月－至明治 9 年 6 月 & 72,626 & 38,153 & 19,513 \\
\hline 自明治 9 年 7 月－至明治 10 年 6 月 & 73,120 & 38,661 & 17,098 \\
\hline 自明治 10 年 7 月 - 至明治 11 年 6 月 & 93,205 & 50,181 & 27,656 \\
\hline 自明治 11 年 7 月 - 至明治 12 年 6 月 & 103,393 & 66,269 & 24,156 \\
\hline 自明治 12 年 7 月 - 至明治 13 年 6 月 & 110,330 & 76,839 & 30,043 \\
\hline 自明治 13 年 7 月 - 至明治 14 年 6 月 & 112,190 & 86,082 & 25,741 \\
\hline 自明治14年 7 月 - 至明治 14 年 12 月 $※$ & 58,684 & 57,655 & 10,948 \\
\hline 明治15年 & 98,192 & 112,740 & \\
\hline 明治16年 & 137,745 & 173,477 & \\
\hline 明治17年 & 137,719 & 196,021 & \\
\hline 明治18年 & 145,230 & 222,498 & \\
\hline 明治19年 & 126,600 & 214,714 & \\
\hline 明治20年 & 96,973 & 185,614 & \\
\hline 明治21年 & 83,836 & 158,257 & \\
\hline
\end{tabular}

※明治 14 年 $7-12$ 月分だけは、対象期間が他の半分である。

出典 : 刑務協会編『日本近世行刑史稿 下』1186頁以下。

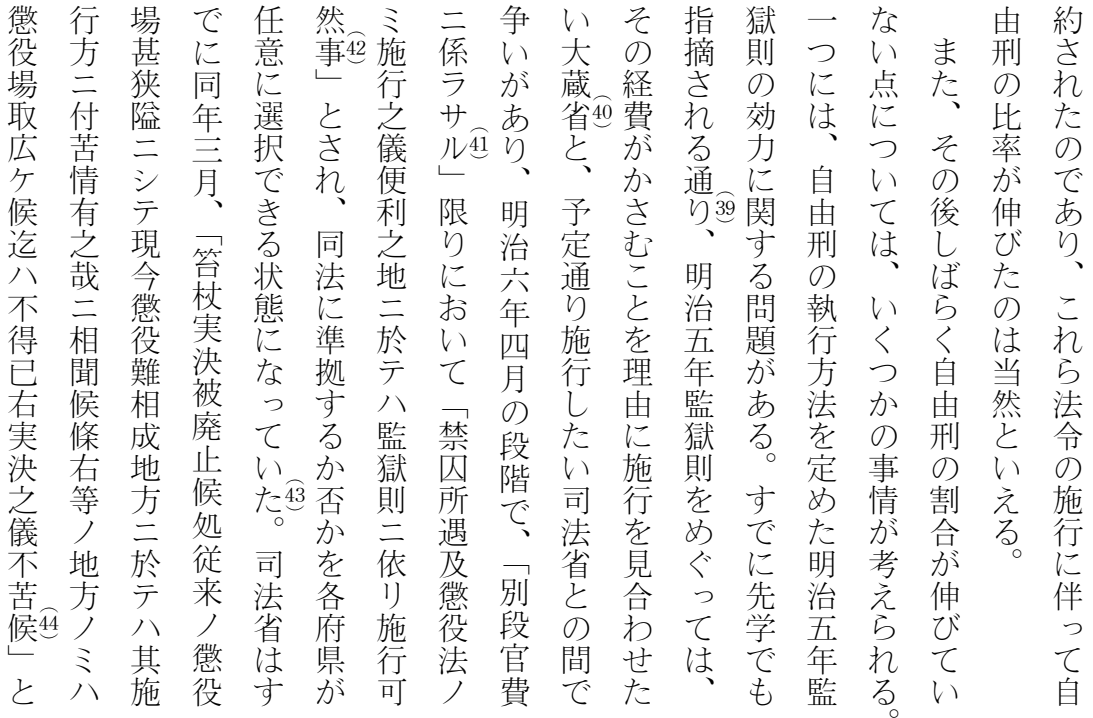




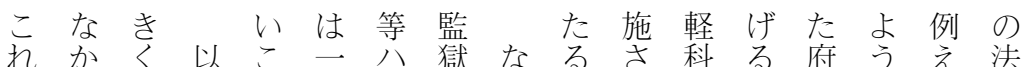

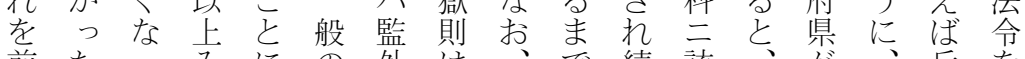
前たっ文にの外は、で続該、が、兵を 提こてて留人, 懲一笞け当埼笞庫出

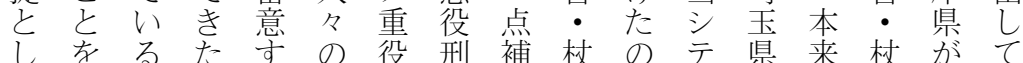
た指もょる目三の足刑で強では刑、い 明摘のう必に服刑しがあ壮は藢は該た 治でのに要触否期て定る。明役後該た

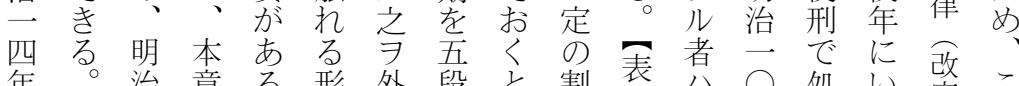
年。治章る形外段之割表分○処々管こ

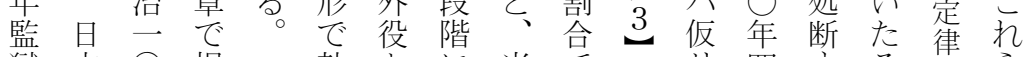
獄本 $\bigcirc$ 揭執贞に当でに四卞る例ら

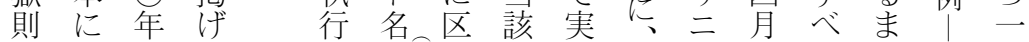
のお代たさク分期施年笞一きで引連 制け前グ扎しにさ年杖日と活用の 定る半ラてとたお机と, 以こ用者法 に身まりい規上けてて䒠降ろさ 注令 よ体でやた定でるい受決受答て害を っ刑の史のし、自た受习受答て実踏 ての地料で皇制の刑と者 用刑著村ろ施ま 气廃方か 它制の刑と者 年者杖る年後え

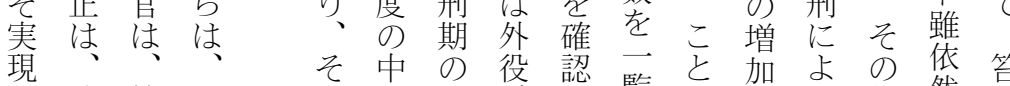
さ改答 明 れめ。治 たて杖五

も自 刑 年

の 由と以 と 刑以降 いをう え主 身 徐 少要体 々

うな刑に 刑 0 刑 種 活 罰 の用に 一 に占

つ め

にほる 置ど自

抵 由

た抗 刑

旧をの

刑 感 割 法 じ 合 と、 㳖

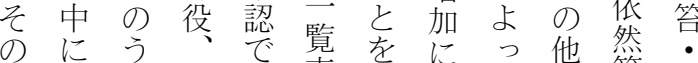
普予ちつき表決よてに管杖 及初ままと定り代は梦刑

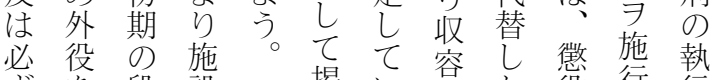
ずを段設揭い谽た役行行 し組階外げる。困ケ刑シを もみにで章難、の の士継 刑込あの学こ棌言続 罰んた労こうなも用年し

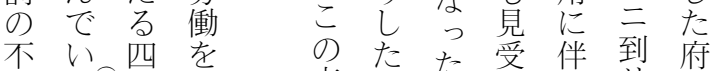

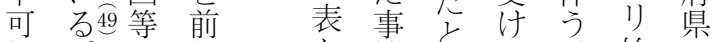
視。提 か情と受始が 化つ五々 ら をま等しては老方者是数 もり、に无明と藢こ增廃在 ら当いた治答嶶れ加止䄈

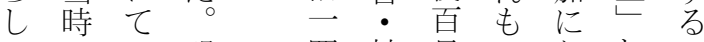
ての 明四杖旦一たしの は自四治年刑以例えてで い由等五には下をかいあ な刑五年い実, あ稀るる。 


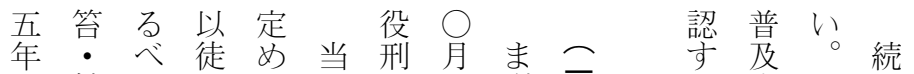
四杖き刑た初ににす、こ度考い 月刑犯被規の改、初合察て

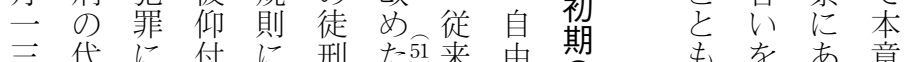
三代に付に刑た可来由期毛をあ章

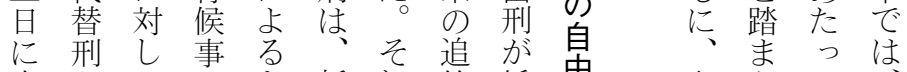
京とて事る新机追放採 都いて候够、政で刑用 府う格徒のはにさ が位格と刑開換れ 制置别のの始こえた 定つ御定虽のて 明 た御型読伴当徒治 あ憫が寛のを年 懲りに挿に刑徒採の 役、に入は化刑用段 規比㫗さ、の・文階 則較学机其環5 懲㫐ら に軽いい方と刑をい は微て科た義しは表て 有犯さ科よ埒て把どし50蔡

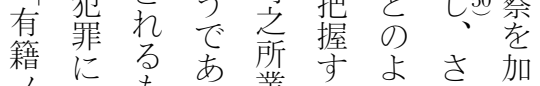
罪のもり業るうらえ 罪みの、致こなにた 人適で徒候と刑明い。 公倜あっ刑付が罰治。 梊されとは少でと五明 ヨてこ急る帒四政 リいと本度。位月府 朝たが来御例置には 暮。わ的処え分は乞 往懲かに分ばけ州 来役るは毛缷身発 可法。可明机体足 為のまり有治て刑後 致施た重之云いで間 候行懲い処年たあも 事54 後役刑格三のるな

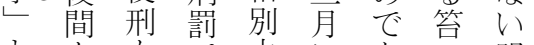
ともも艺にあ。明 のな、処御京了杖治 一心当断憐都う刑元 文明初さ䈙府か。を年

刑

奛
治
䍃
吕
吕
同
吾
年 各えて舟 期ては自規 に四、由律 導 期 本 刑拉 入に稿の场 さ分が場 び れけ対に統 た、象新治 特そとた技 徵の卞な術 的時る規少 な久明律獲 規 の治や得

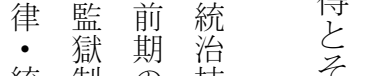
統 制 の技吊 治度示術変 術設年導化 を計間 入 取者をさ

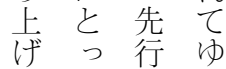
るて 研く と舜究さ 尌者自学 るどの そ の 研 の 上究 背 う成 景 な果・ 存目 在さ的 でら つはも た自に か 由論 を刑じ 確のた 


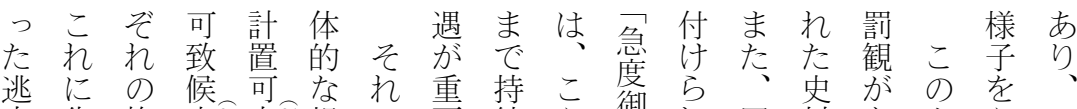

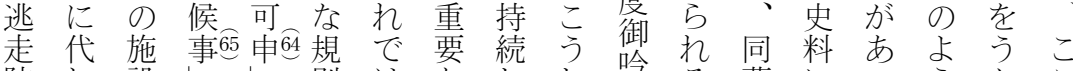
防わ設しᄂ則はなしし味る藩にっうかこ 止るをと、をを政たた味もははたか 目間運し今制当策理前々の慶、と、え 的頭営て般定時課甹提綮で應徒考徒る。

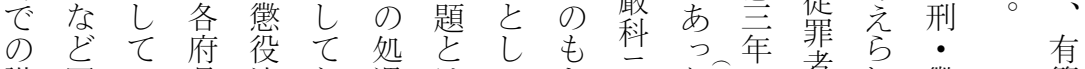
識见い県法お遇はてと市た57 者枝懲籍 別人たに被ら規意はに被を喑き軽る役の 法自と処相ず則識成被さ罪异。刑受 の治さ遇設、注さ当り処ら人藅徳が刑 採のれを候そどれ時立者に佶罚川比者 用継る而委條抵の 徳司て最れうな期い得都とと自穏 川片早い懲ななか受た共府呼と星や 期眉近た役徒もっ刑と格かば記刑か 以両世近方刑のた者及格られ記にな

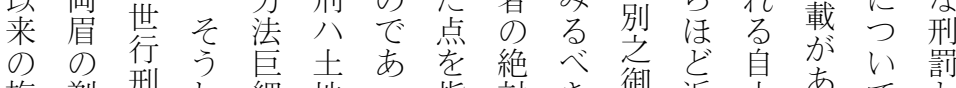

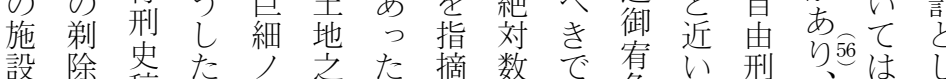
設除稿た儀便ろ摘数で怎丹型、先て

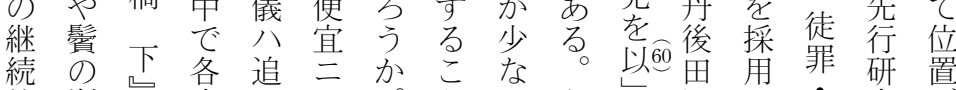
的剃府当。とかな七辺し徒究 利りに県御りこがつおて藩楿た徒のけ 用落揭は達各のでた仰㹸が刑蓄ら 々げ、可制時きこ徳せも付も賈れ

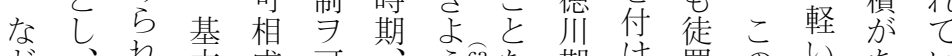
ど、れ本成可欺う的な期り罪のい市い

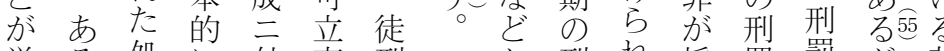
挙る 処に付事刑 か刑れ採罰罰が背通

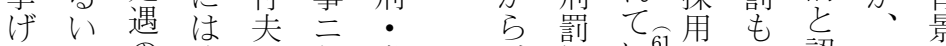
らはの徳迄付懲、観い苜さま認例に れ衣特川少府役政㤎る敖た識えは て服徵期処藩刑府明明て辱䒚長徳 る67の示処地共処と初治たきて 州川 文世遇方基遇方期初が59御い藩期 試学ばを, 見にての期、慈た菜か しの受便込関自徒のそ悲こ天ら に染牢け宜兰紧刑徒こ学と保の め名継三従て刑・刑で以が年伝

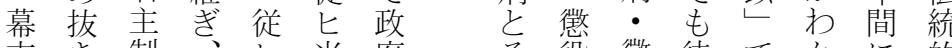
末き制、比当府役藢徒てかに的 のと度々役分はの刑役罪仰る記な 長いや机取具処に刑はせ 施 設 に 収 容 せ ず 宅 か 5 懲 役 場 通 せ た 亡゙ 作

業 徉 事 さ せ ( た 


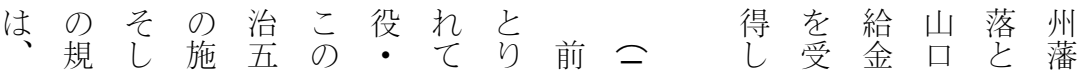

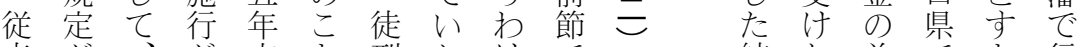
来が、が末と刑たけで各統た差でと行 と置同各にがc犯改み各治も異採いわ のか法府は、異罪定て府技のな用う狽 大れ 令県、行なの律き県術でどさ逃た まてに に

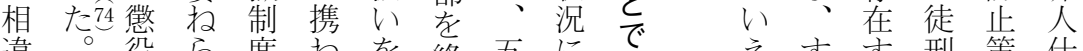

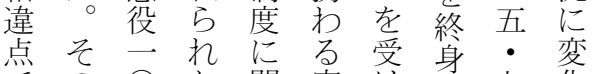
での○た関官け懲主花 あ結 ○たす吏て垼・が つ果日め码るがいに二生 た 外卡効初長た換 年艺 役のにて受流登光の の に者はの刑のさ刑は 従と限 基 者受と期、 事、界本の 刑々 䍊 寸二が法存者し設役 る年あ令在やた危定法 当上た明目死乙れよ 数のが治の刑れてび の刑、五当にれい改 長期各年たょ伴た定 期を府監りっ准律 受毛県獄にてい流例

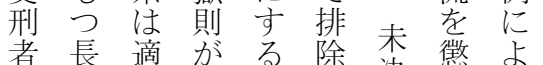

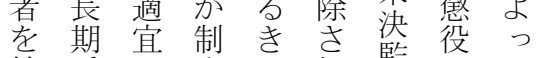
管受同定っれ監にて 理 刑法さかてに統受 专者令けい隔一統 るのにたにた離す者 必収準。な者乙る方 要容拠こっがてと急 が初しのた、收と増 生期つ法 $匚 一$ 容もし だにつ、令考つされたた わ外処制 万施る従治 け役遇定れ設な来六 でをを後るにど71は年 あ行行間。収、死以 るわつもま容従刑降

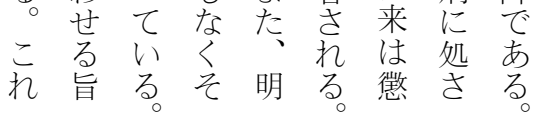

え 卞 刑策佶

規每に゙るにや役

律に徳こ監の

統な川业督処

治高期は啡者遇 の、全

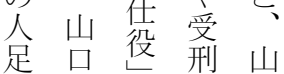
寄県で者口 場にはへ県 で限確注明 同て認意治 様みぎ事五 のれき項年 処ばななに 遇新かど採 がたっに用 行なた共さ わ制吾通れ れ度等点た いいに見刑 る68 $え$ 出の るる守処 とがぶこ遇 か、受と炎 ら、刑がを 明ら者で比 治之吼 。 期東分。乙 に京や一 み な府方る このこでと. て新則に明眉 たに応治を に影じ期剃 獲響たのり 


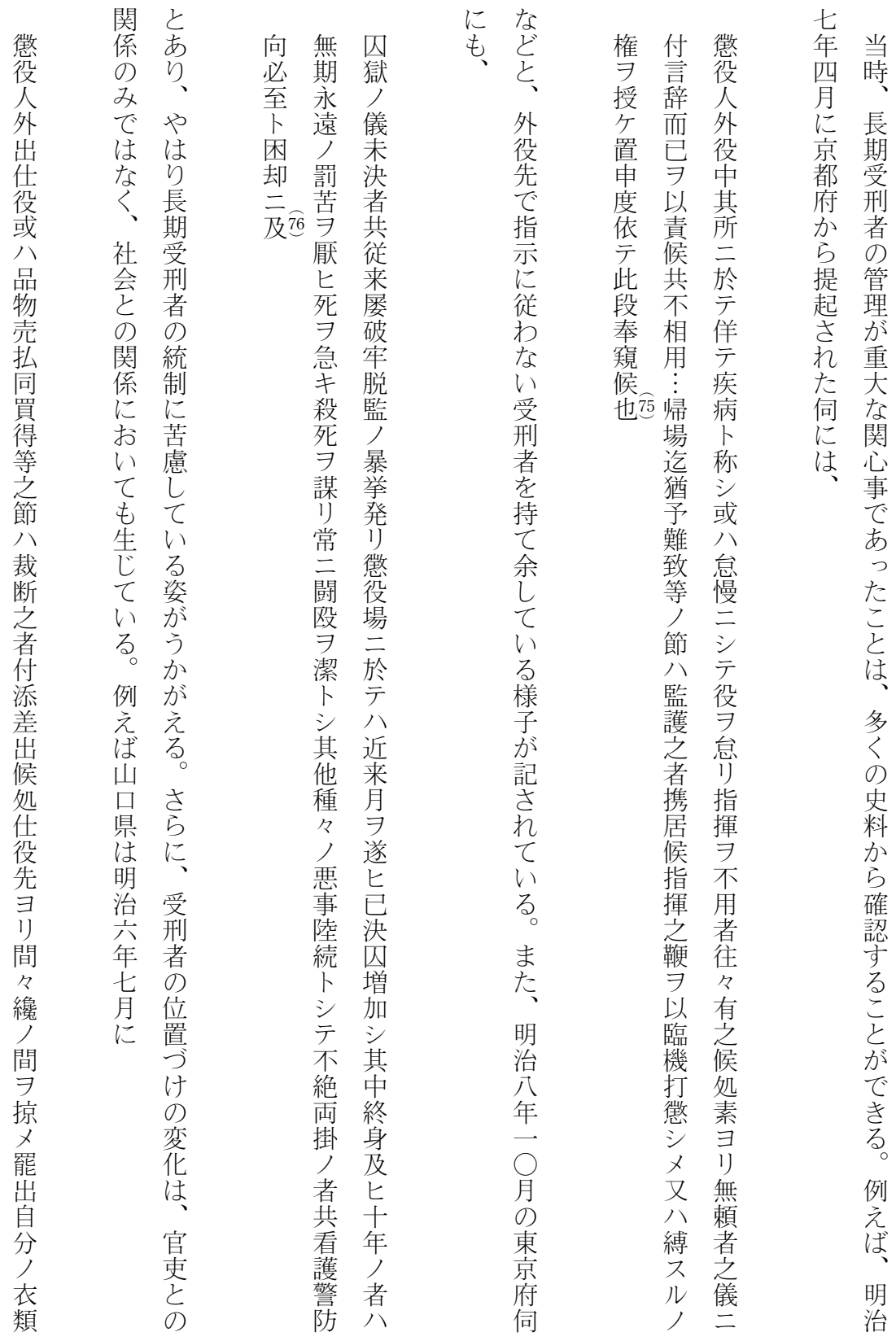


八規社き存期般と

年制会る。そ在受社の

定書変例しあ者令

め信化えたるのらるを

らのとは変と存隔出

れ授も化認在離し

た受呼明を識がさて

群に応治受し明れい

馬関し五けた確るる

県すた年て、のにべ。

規社獄当あら存連

贝定会則該るわ在の

人の復を期。れで法

歩細帰受にたあ令

行分にけ各こるか

之化向て 府

概は、け、県

則80、て 食 で

受の事定

は刑施・め

、者 策 就 ら

资のと役れ

資 管 解 等 た

料理 寸 $す$ 処

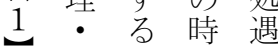

に統 こ 間 規

に制とが則

文とが詳に

5 いて 細も

れうきに、

通点筧交定律

り、㔔。り の

らま、面

外有た教监鿊

をな施に来

行規設関 と

う律 内 市 の

受之外る相

刑いで規違

者えの定を

にる79禁が見

対步置出

乙 特 事 加

てに項れ こ

隊 明行点 が

列治動はで
と方䓍壬柿

に考は菖忘等

よ之、

乙両井

者 の

行の人

刑接 々

に触と

わ断刑

ると者

官うと

吏との

の し 間

側てに

は、交

る 流

受 様 が

刑子あ

者をる

が み 中

一兀で

般々 れ 山

人よ口

々う県

は要 が

違 采受

万刑

異に者

質、は

な 長一

ル相 目

聞印

ク、モ

此甚有

旨以六

掲都平

示合人

者人同

也7 78 事 様

候取

扱

去 三

ル不

明 相

治成

六次

年第

七八

月 明

及白

掲 三

示 有

置炅

儀 処

有 間
と

右銭懲 の 壳 其

様 当 役

取貸 人

計店 役

七頭

シ 三 節

候 飲 胿

者食煎

於七附

有 シ 添

之又且

分候 刺

屹者眉

布払外

達等 売

不払

相 又

成八

候 品

受 万物

刑一買

者 相 得

之背 等

井云 致

の 候

人八者

久可有

の 為之

自曲哉

由 事77 二

な相

接聞

触 へ

を不

相

済

事

候

向

後

付

添

人

無

は

明

治

九

年

匹

月

当
落
眉
者
当
品
物
買
取
候
義
八
勿
論 
【資料 1】囚人歩行之概則（群馬県、明治 8 年）

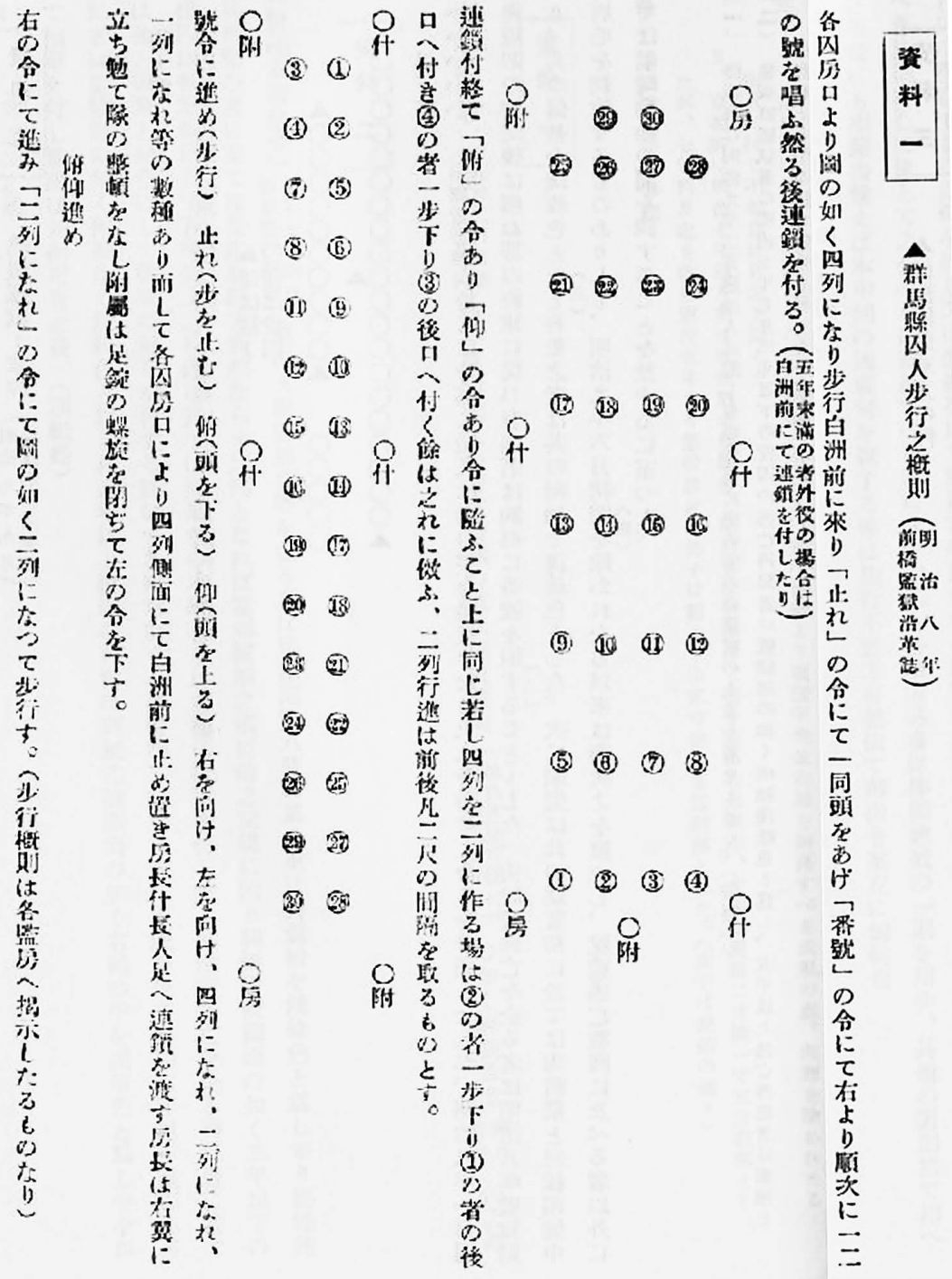




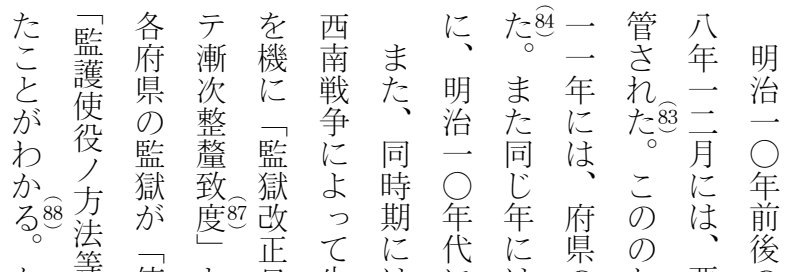
な等使と正生は代に県の覀後 お、理役の的じ内は、要東化監 後整卡意立た務各各望景卞獄

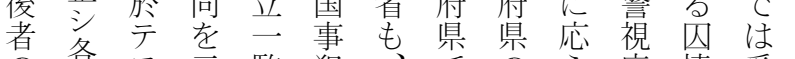

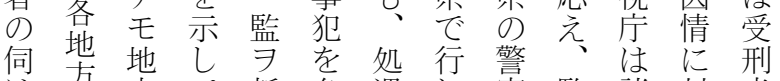
は方方て 新各遇わ塞監諸対者 長夫区い築地の独察獄規応が

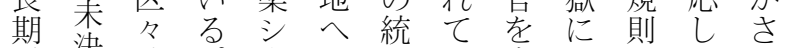
受決諸。当配一䋨東ま向きら 刑監事さ省置とた京つ整れに 者俥整ら当し監独府わ備な増 老罪整にりた獄自にるををく加

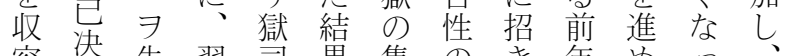
容獄失翌司果集のき年めうえ

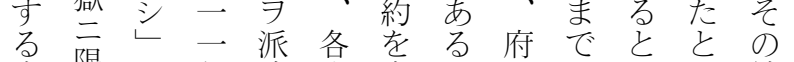
中限て年遣府意処下のと統 央其 い五 三 県識遇の布もて、制 監其る月テかしが監告に、は同

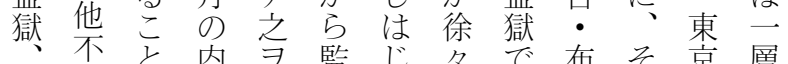

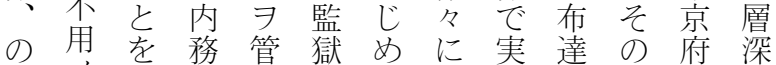
ち北問省理のて解地 - 経下刻 の 獄題伺卞建い消研指験のな 集舎視か一築るさ修令の監問 治八し 5 体。机孝等他獄題

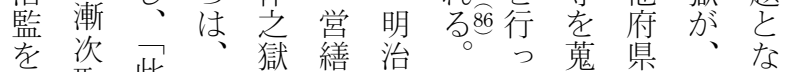

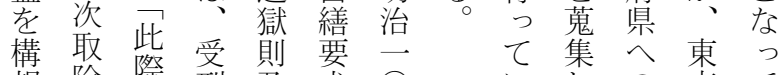
想除祭刑及求 $\bigcirc$ の京て 候永者七年年た周府い

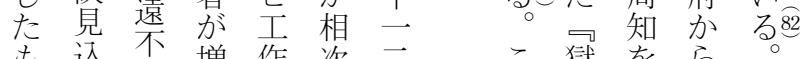

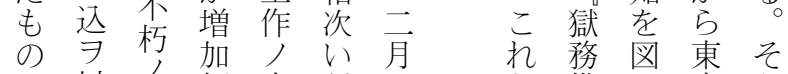
で以獄傾方だの ら備る京う あ夫獄向法と内可版。警し り然制に等し務動例視た

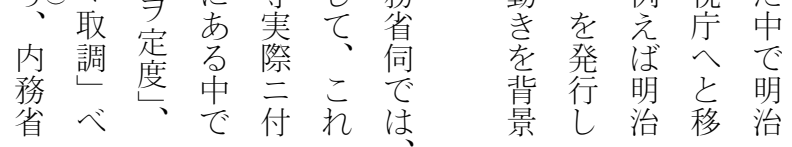

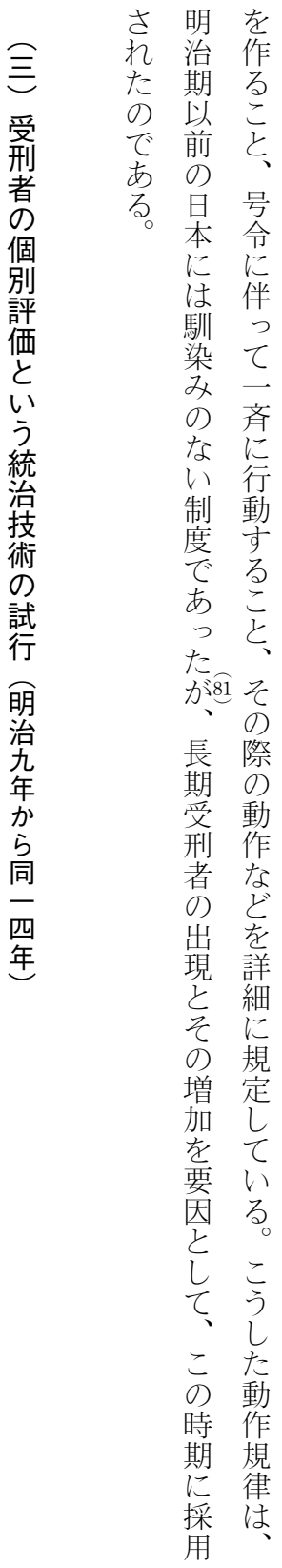




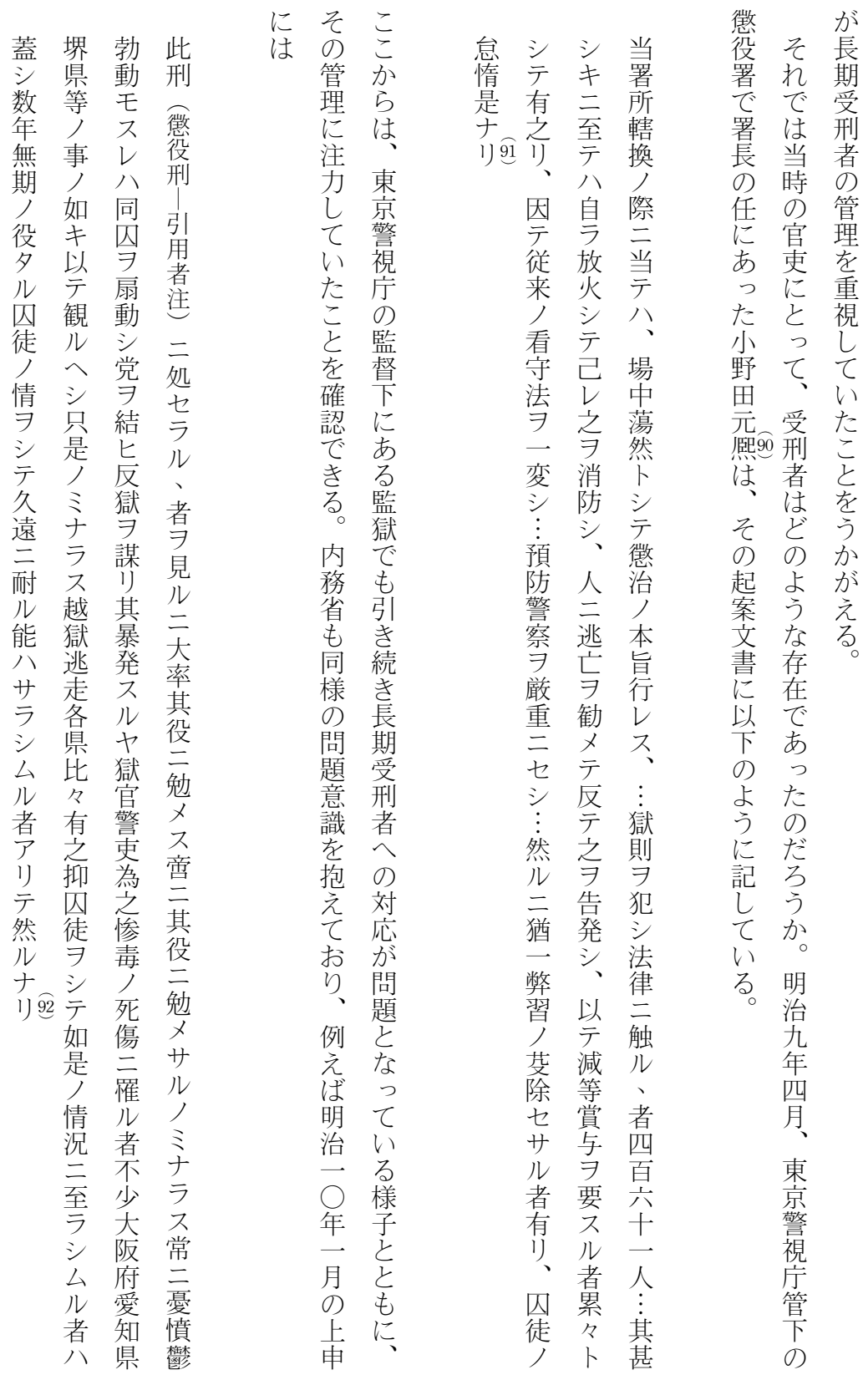




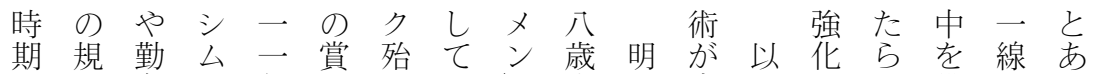

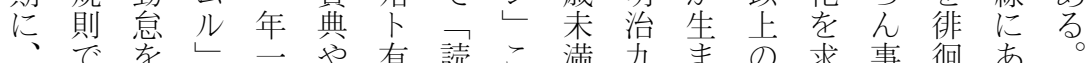
管は 評と ○ 䍐名書と 理価し月惰 無算に受三主約或た期 要教守たにな実術あ刑月活にい方は石受 る育るほ制者ノ公つ者、用、る る 銭澤刑 側内なか定へ形をたに東さ行。に幣謹者 に容ど、さのを教。教京れ刑至を吾多が

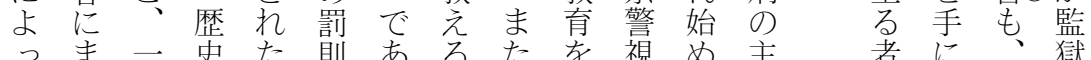

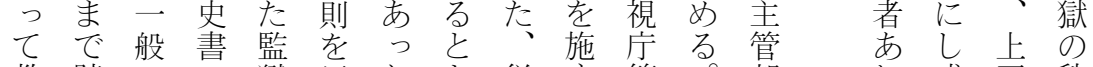
教踏の の獄用たと従守管。部和或司秩 科 又 学 講 署意こも来も卡々局とはへ序

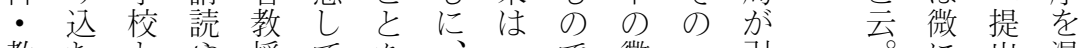
教むとや授てををで懲—引引出混 材こ比算場い踏や其、役つき がとべ術仮る踏は教そ署と続願体たさ

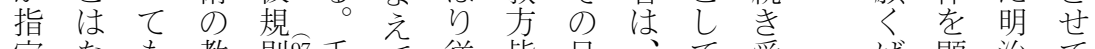
定な孝教則97千䔶皆目、て 受 ば顕治て さく、見授は葉、来旧的风、刑 今しい れ、劣を去、県生、来は人監者に婦二る

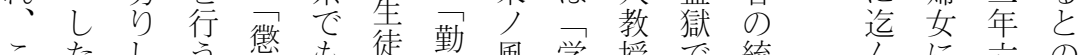

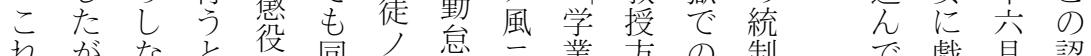

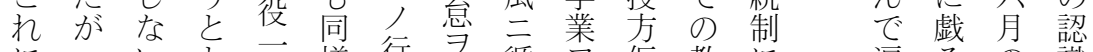
にっい亡 年様行 状督当仮教に遍る の 識 対て 教も年の状督 ヒ習規育心意を す受育に以規 枝責書公則にを各等賞み る刑機、上則鼓 ス籍シ学関砕 県の書て 受者会試人形舞儿慗又制守い寺事にと

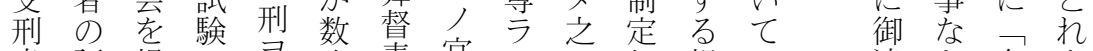
者 評提に 寻次責官四三し規い達きき各よ

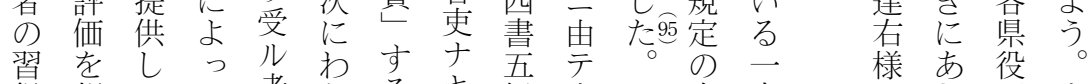
得想てて者たるキ経少こ充方

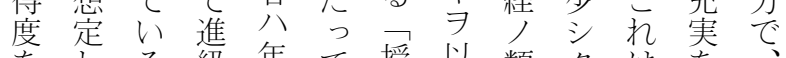
確た る 級年て 授 以類定教 知署挙こ 認制明落並め走生止識满孚 - 度治第在 らを徒匹 評で五を学れ任往ま開口こ期 価は年判年た96命々つ達仮とに 守な監定期がし、警て 学がは るか獄し、、、戒い悪校で興 シつ則、定な成勉た意尔き味

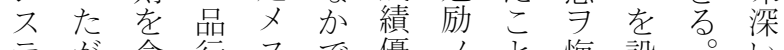
テが含行 スで優少と悔設。い ム、むの就も秀意を改け統 がこ従良学明者云反セて 治 導の来否セ治へ薄省シ 一技

不ら见ま 取ず締合た の聞情 小 義く存野 無 処 見 田

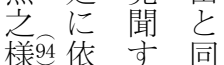
机る様 とばにに 記放 $\vdots$ 監 ᄂ,兔网 の人行 規 後 独 政 律夫 歩 の の妻市第 
明治前期の監獄における規律の導入と展開
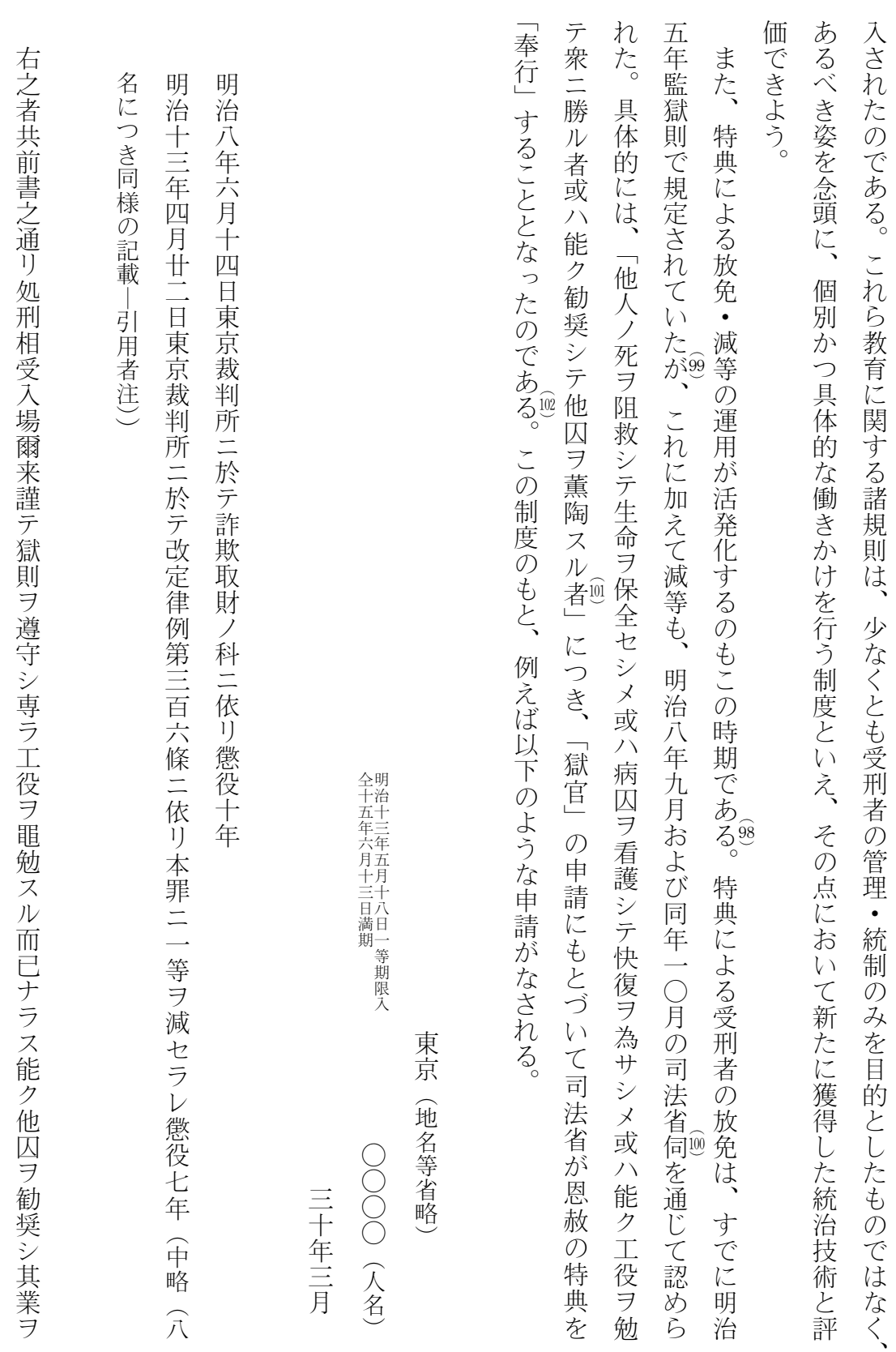
て 改 例て が裁 史

以以之悛之勤認判料 る。卡产は吝め所に

こて刑効資查机事げ

のき者と料や局た

技た㳀上動っ 2 行満云記

はう機たに監よ政た

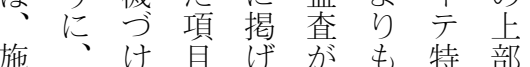

設こををた導八典に

内の行判福入力放朱

の時い定岡さ月免筆

規期、し県坊苂あ被で

律に一兀の成一

をは定い已先り事十

遵、のる决の早四

守受方。苜特く明年

さ刑向こ行典出治九

せ者へこ状分所十月

をを働に勘根し四廿

さ評きみ査拠た年九

ら価かた録吕とも九日

にしけ行でしの月特

監、る状はて と廿 典

督そこ監、、思九放

者のと査月受わ色

の結のとご刑れとヒと

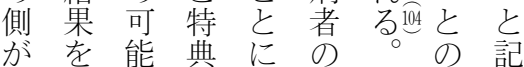

求刑なは受日さ記さ

めの統刑常ら載れ

る 減治改者的に免掕の明あま

材に術の品監治るた

へ結と度行視—こ史

のびい合・・ 三 と 料

陶つえい信評年か未末

治けよに心価頃ら尾

をるう応・がに、に

行統。导役行はこ展

う治て業わ向右

に技刑・机一者拾

あ術の賞る部に一

たが軽・よのつ名

乙編減罰う監い主

て文文に獄て 者

効出認病なには共

果さ め気る。市東

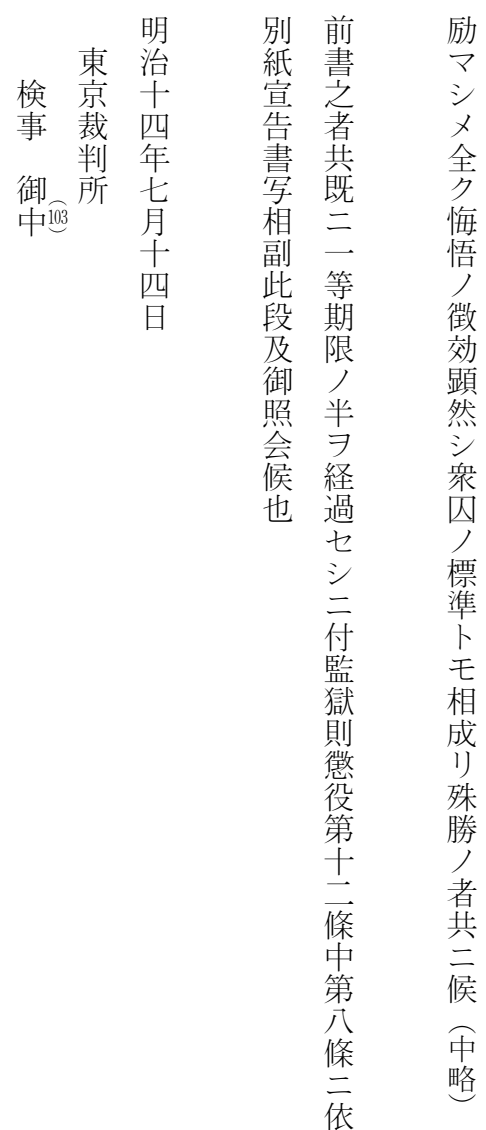

的机当啨京 
【資料 2 】决囚行状勘査録（福岡県、明治13年頃）

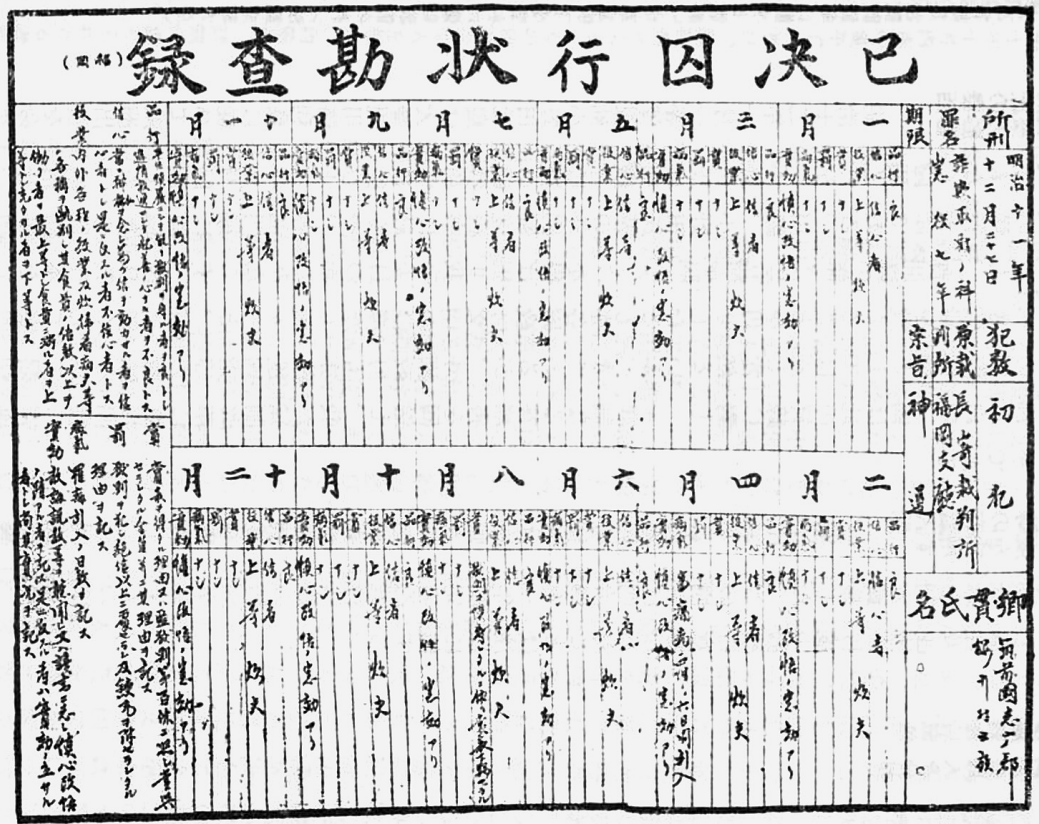

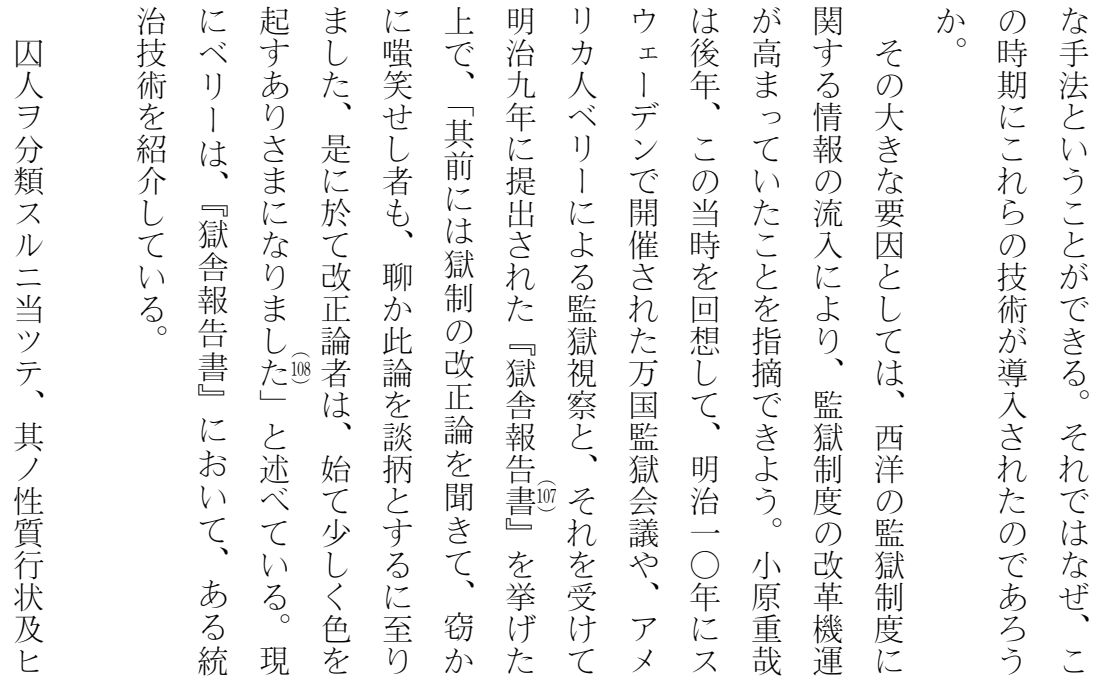




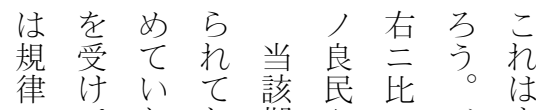

のてたお期多スベま

遵、のりのラレリさ

守個は、動シ公! 壬

と別替統向丈其は、先

も心塄的ま事重罪に

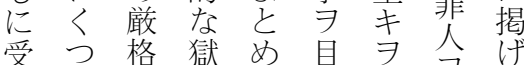

刑か化制る 的覚习的

者のでのと䛃㛜特

の試あ導、ジ㥀告

改みつ入監テと徵に 善もたに獄是し微よ 老行と向制主て言る 促わ多け度教い合放 寸れてての化わ允

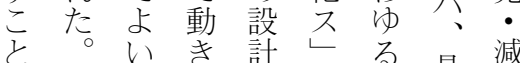
のそで始にる感是等 可のあめあこ化しや

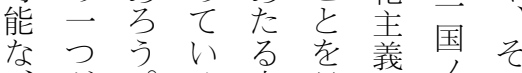
が。る内貝・常の 新本し。務指誘常背 な 節か そ 統紹々 結 側い義110 あ 治介の果はるをを踓る 技し一が、の採雖行 術た方集前でり壬状 い行で治半あ不監でる其衁 え監西の具 み其) の る查洋設た兑道理 もと立よ 罪德論 の特監に方文的

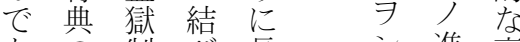
あの制び長 シ 進裏 つ活度つ期 テ歩付

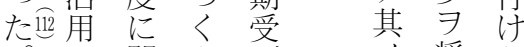
で関よ刑奨と あ市う者国励い りるにへ法スえ 、知、の

こ識彼対遵, 毛

の の 5 応奉常の

方流がを ス務で

法入求迫儿八あ
人師是 シ 方 $习$ 獄 其 四二レテ法施則了 ヶ因二是, 学改功 條ツ贝レ因、良労 ナテ人力テ各三 三 リ 109 信, 為益自付因 認品メ々二テテ サ位 贝贝是ノ是 レ下人人レ緊习 夕顕八 ルノ益シ 教十分 贝四々テ化儿ス 人箇帰 其シ 要ル 帰條善了、旨习 善 Э分行而ナ最 )明心状シリ モ 志示 及 ヒへ固否人故ナ 其シ 二 規 二 人 ス 斯 則 凤 進第へク 人, 歩一シノ因ノ卜 人如 最 ス 度人此 クテ 平ノ官 誘ナ： 第 素 方 吏 導 ル 四了法三十進、 学行 於レ歩コ 校状施テル习ン 教 行 視 所得 千 師第 ス察, ンレ

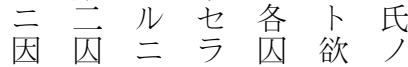
ツ人当ルノセ著 テ勉テ ル行 八述 信強 ツ事状、獄 認及八今二宜舎 サ 匕、知注 レ労各亏目ク轄 夕功房 ルノ三メサレ三 同度一能儿二曰 上, フ可二ク 第牌へラ般、

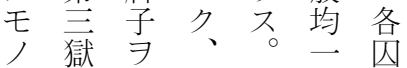
則舎揚然又, 分 千 宗厅、门 斯規房 此教、而, 則八 


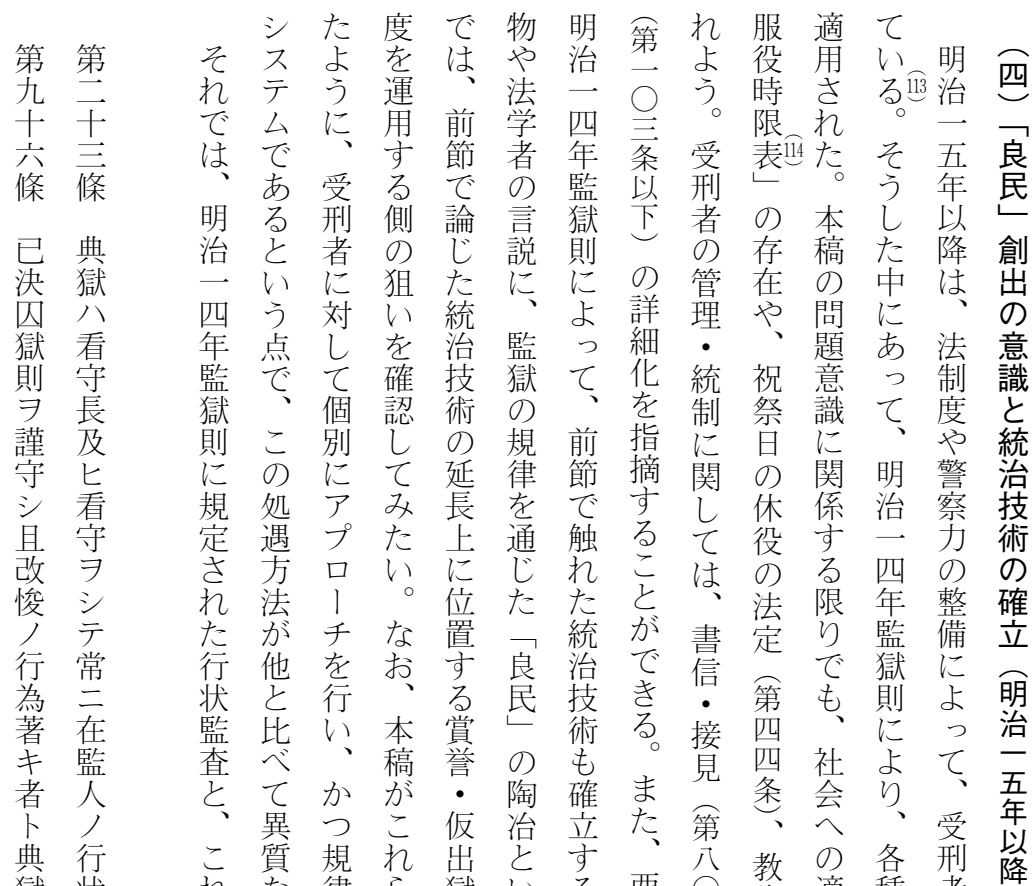

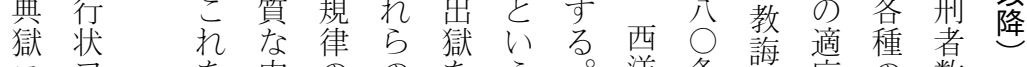
二ヨを内ののをう。洋条誨応の数 於録踏容遵統取意さ法以教に規も テサまを守治り識らを下損律引 確シ え持や技上がに本や竞守がき 認メ たっ 社術げ明こ格や相る精続 ス賞賞て会をて瞭の的禁垁規緻き ル罰誉い復あそに時に路る律化増 卜马制る帰えの あ 期継事る 規と市加 キ 行 度とにて

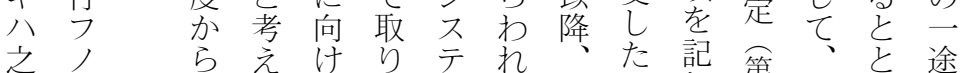

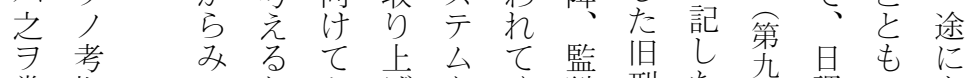
賞拠てた心げをく熦刑た光課にあ 誉卜いめ理る紹る制法揭桑老的

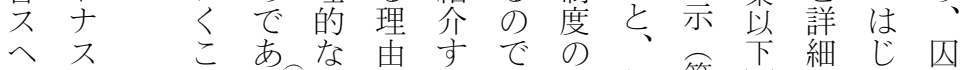

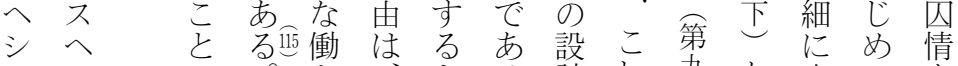

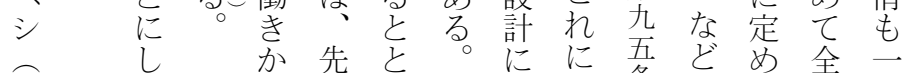

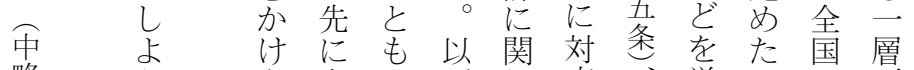

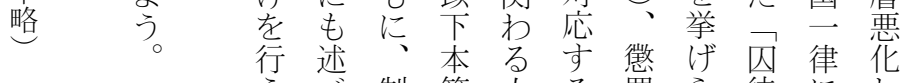
う忍制節人る罰ら徒にし 


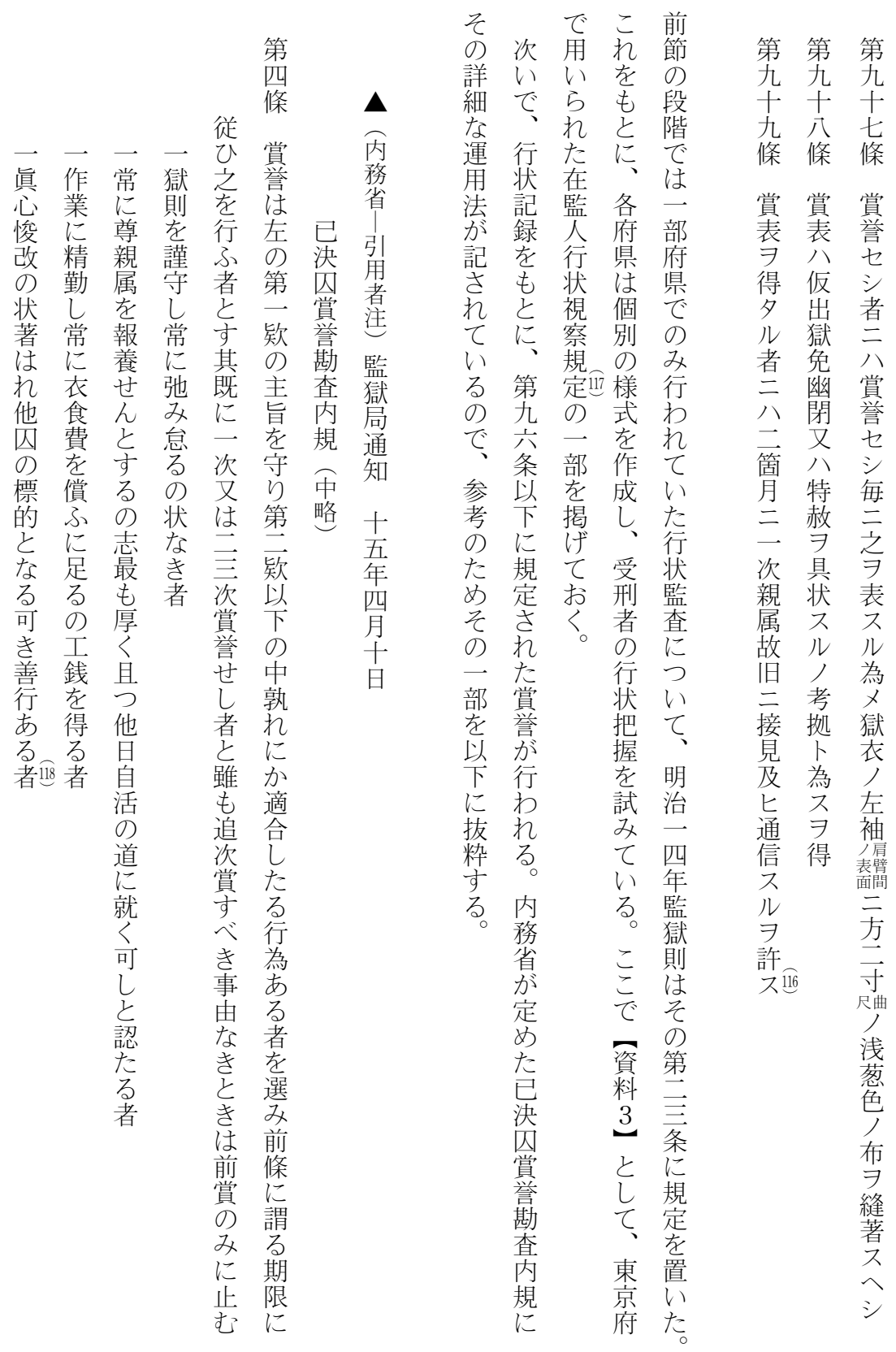


明治前期の監獄における規律の導入と展開

【資料 3】在監人行状視察規定（東京府、明治19年）

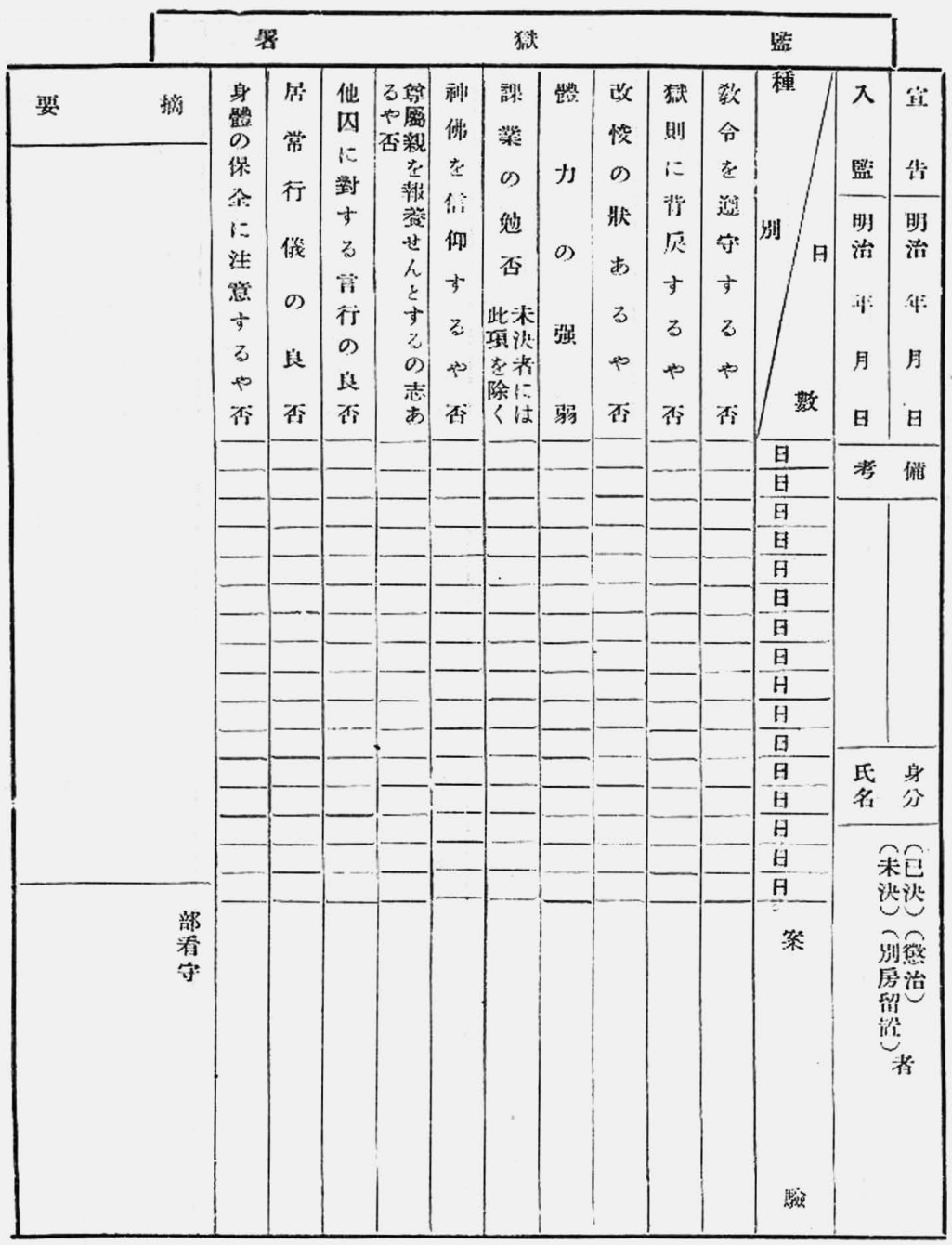




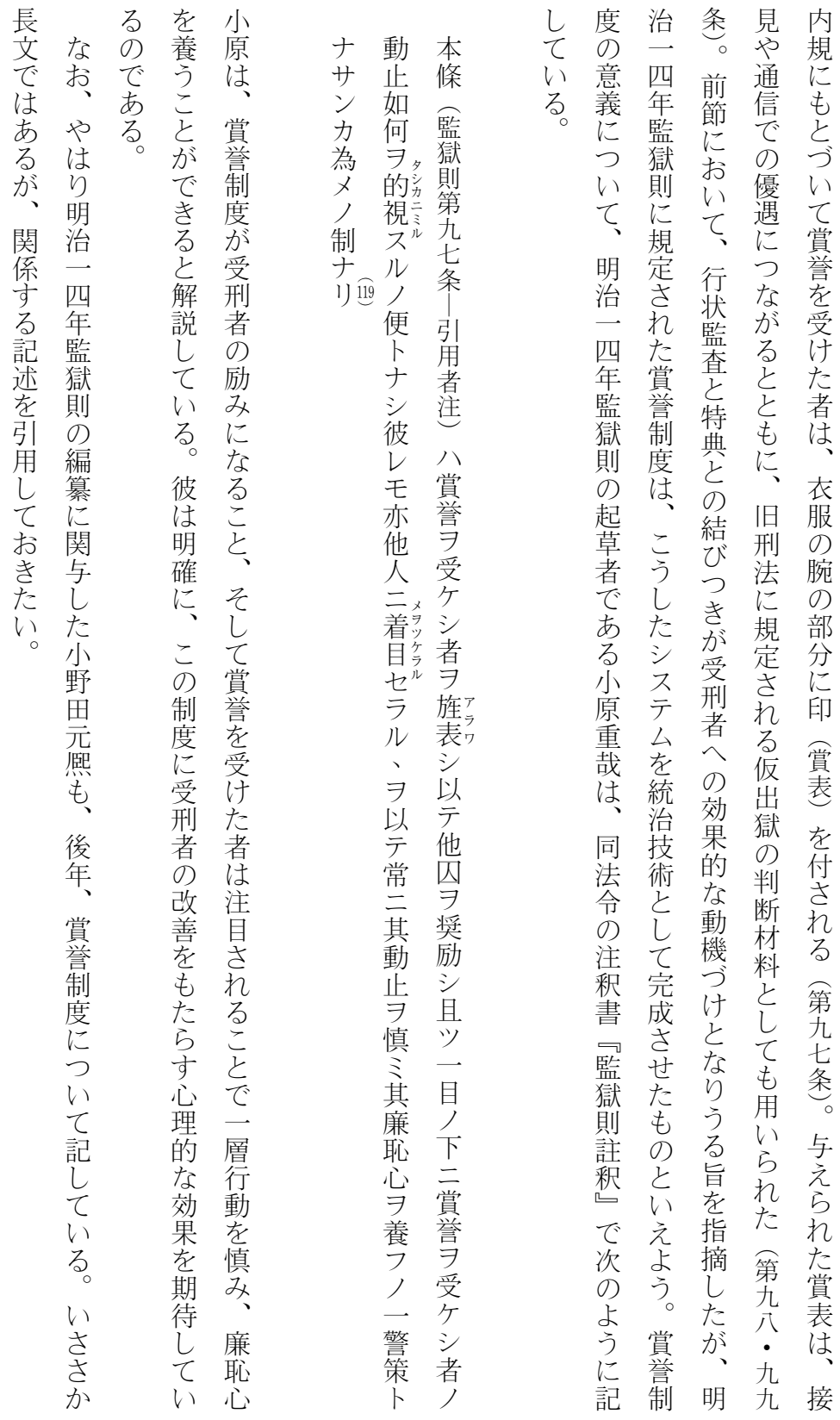




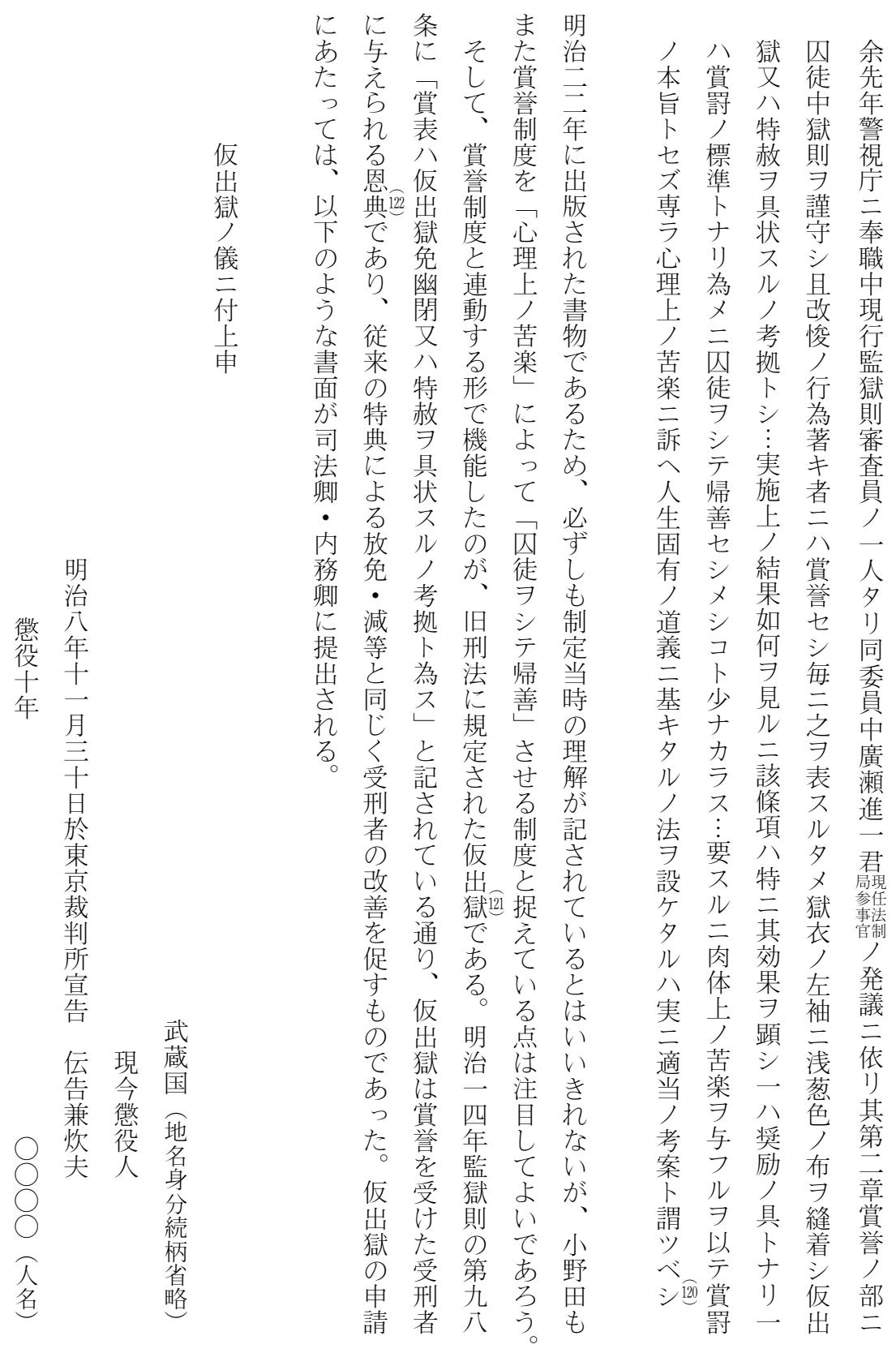




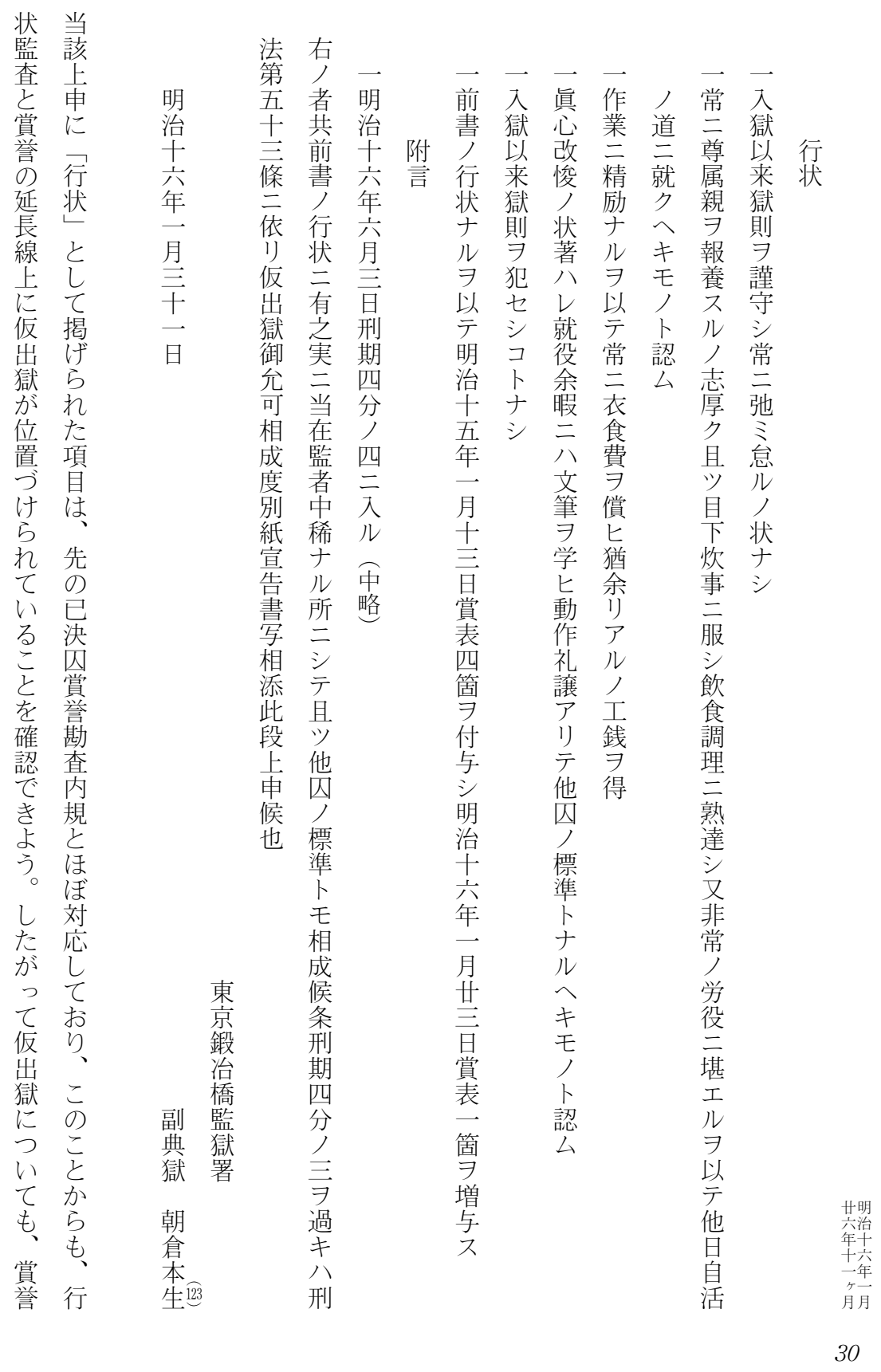


義 みこ

さでの 欲ル悟十

れあ示 ス二ラ四

るる諭ル至シ年

言之は 力

葉述、

でべ賞

あて 誉

$\begin{array}{ccc}\text { 警 } & \text { 。 } & \text { 出 } \\ \text { 察良 } & \text { 獄 } \\ \text { 行 } & \text { 些 } \\ \text { 政 } & \text { 含 }\end{array}$

に上它

お方立

い連

て の

は其 制

明 操 度

治 行 が

一正、

$\bigcirc$ シ 受

年 ク 刑

以、者

前職に

加業

5 改

、勉心

一 励 帰

般 シ 善

市、ノ

民能行

を状

父

良 桨

民二 励

- 事 シ

不 、—

良人良

民事 民

に堪に

分へ戻

類 得 市

し儿た

者め

素告の

行と仕

の定 組

皆, 則

キ 習

楽 免 テ
為 シ 加 ヒ

メ要フ ニ

ナ要ル之

ルス二

ノル賞

監

之例引

徵 備 用

戒气者

感 テ 注

化 以

テ 改修

泉正

民帰主務意

善業詢は

地人㮍

位行定

復 当 天

肾桨 励

自励 以

活 字自

職 今食

業逐業

就 效

均積,

シ シ シ

社 テ 教

会 仮 誨

快 出熇

幽以

受閉 テ

ケ人自

シ 恩 新

メ典,

人营道 时

る 期 山 県よ 有り 朋八<smiles>[AlH2]</smiles>

務 レ

の ル

示 の

諭 言

を説

揭に

げも

가

おて

きと

たれ

i)

そ

例

例

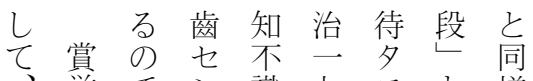
誉でシ 識七スと様

明・あメ化年身し、の

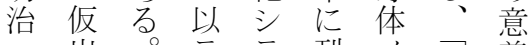
一出。テテ刊ノ口義 七獄 其畺行自多 が 年の再ノさ曲名語 一解 良れ引重 二説 犯民得重れ に文多堀セ沓る 開 5 ᄀ 正么犯例 催れ $れ$ 得忠儿无え さた予セ可前ば れ統防シ 刑在韭磯 た治スム法儿彗部 監技儿125ル釈 $习$ 悔四 獄術 二義以上郎 事 の至它 テ誜は 仮并之者出 にこ 仮 益崖在情獄 おの獄营出雖アを
○獄改者见

贝ラ引過公今 徒ン用遷独シ を仮乼善 無テ $\neg$ 出 心 期 悪 良獄 民制六発ミ洗 に分漸儿ナ滌 変独罪二 え罪至不良 て 贝悪儿有心 く蓗罪 シ 刑 煥 制善悪乞発 度道多尘雖セ あ誘 $习<$ 这刑么 る 導知。期 とシリノノ 主良遂た満最 張导不明 主
が少出獄 毛儿品 


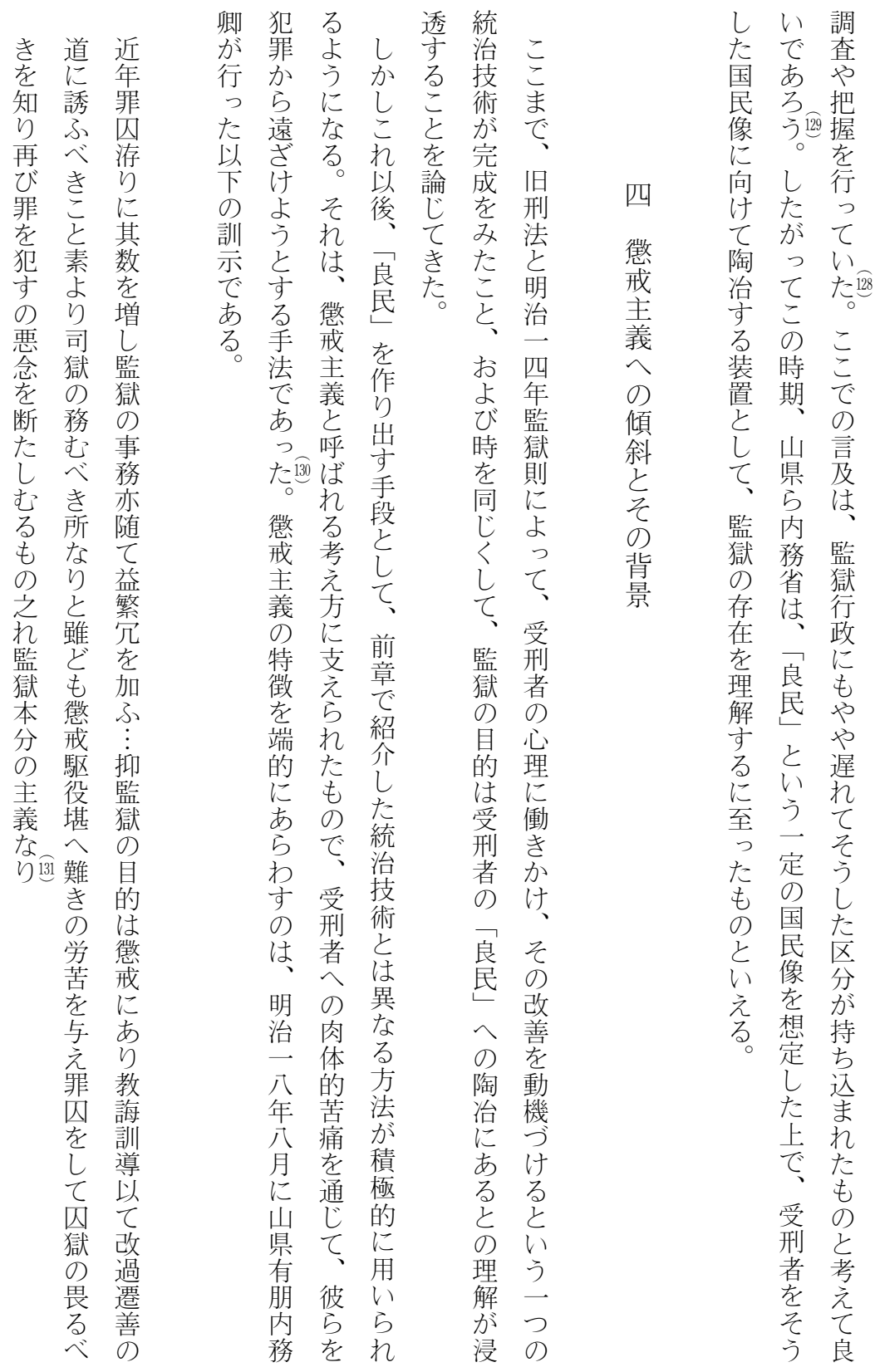


明治前期の監獄における規律の導入と展開

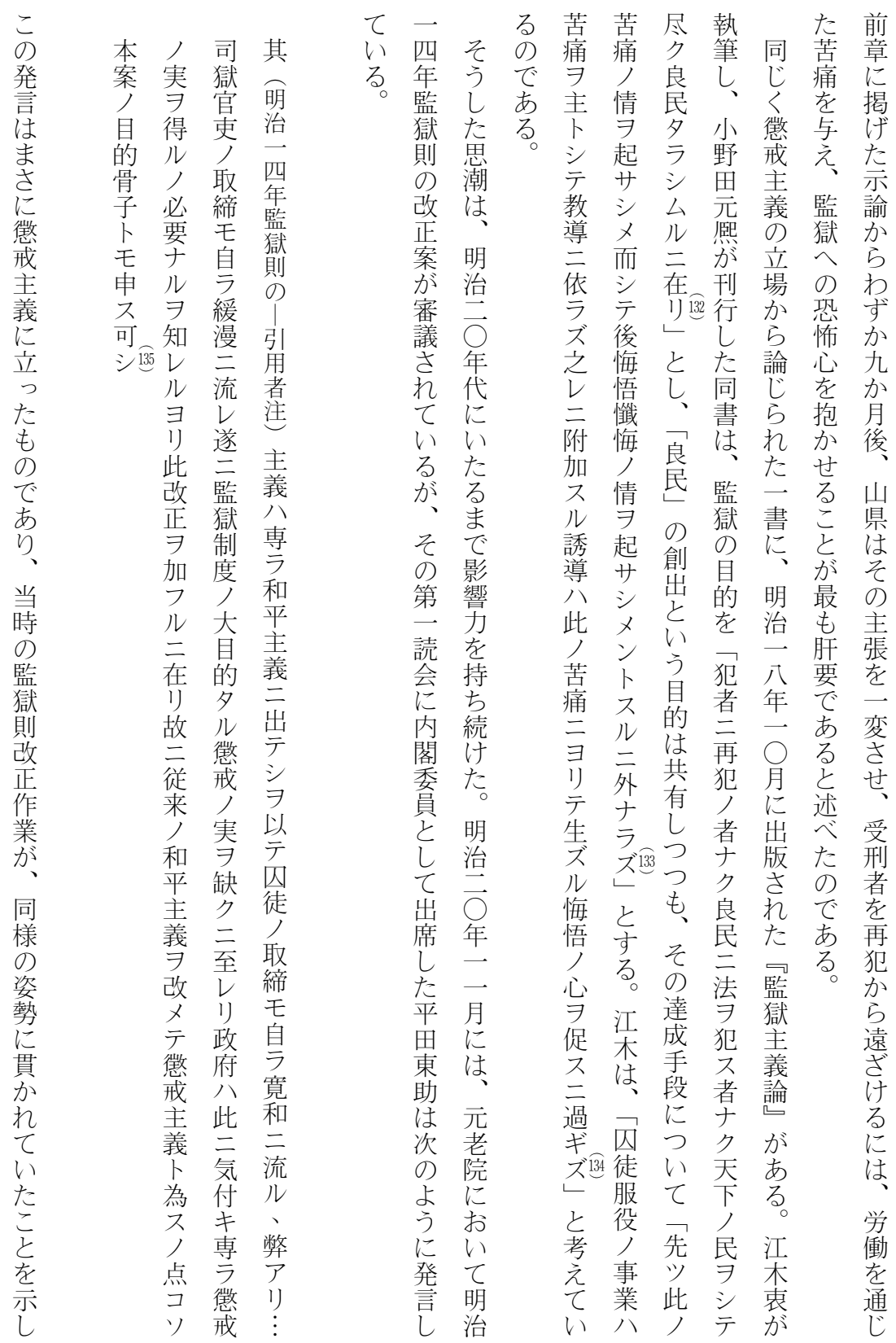


てるいがつ

被いとえでまを事テ精

収るしばきり、業監神

容こ、毛獄上

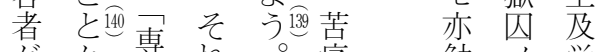

がか専れ。痛勉, 労

行 5 教はそ学年役

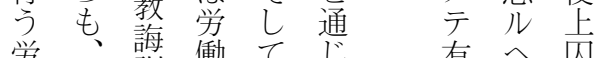

学、訓働て、岌 有へ岗

の 働 導を゙懲特 益 キ 感執

目は方つ戒別

的明方た 主予

をら法義防

良で欹山県論戍

心ある亦者る

のる。曱

涵。示具

養やが体社

や や 的会

生可懲に復

業役㦳何帰

を得集に駆に重

る 利 堪 つ 視

こ 潤 㙃てし

に主難苦て

置と年痛特

専営与予

か、専苦え防

苦作与 园

痛業へ懲る

通製レ戒か

点尼このそ

た従と效の

懲事が果バ

戒せ七を

にし監得ン

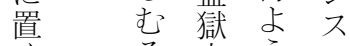

く る 本うの

か も分と問

と の の し 題

いを主てと

う議批義いた

$\begin{array}{llll}\text { 議 批 } & \text { た } \\ \text { 論 判 で か } \\ \text { は、 }\end{array}$
す 者の でそ れ 両天方 者下 うは⿱ 訓。 相民。前節市 点 シ 野ま品内 にテ田でし務 つ尽元にて 省 い夕熙取 いが て良の泟毎 は民著上年 次 多泰た だ刊 の シ 西統少し よ厶監治なて う儿坊狜技くい にこ問術皁た さと録背㠰功 れに後可程 てあにに期 報 いりよあ間告 る、れる的的 れば誘藢は、 は監主主明 懲獄義義 治 戒の に に一 - 目感 九九 誘的化 る 年 導は主こか

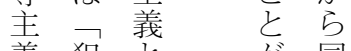
義犯と が同 の者、内二 以懲務 二 ず再戒 省年 れ犯主公に にノ義公か お者と式け いナの 見て て ク 違 解 共民は治 通三ど こ で法こた公 あ ヨにと年 る犯亦考八 


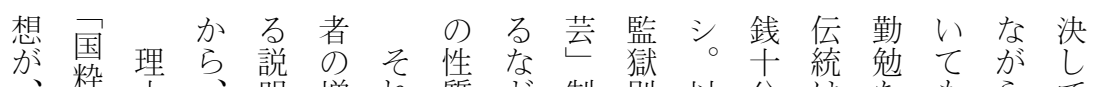

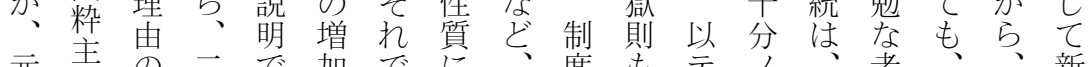

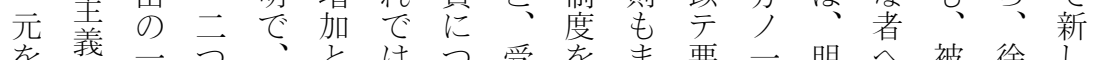

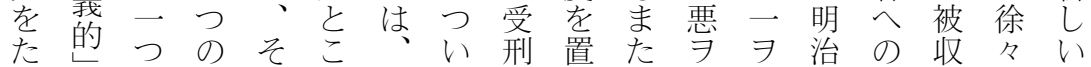
どとは理れれこて、者い直机給期刑容にも

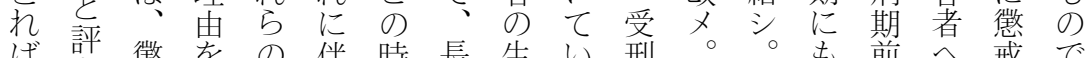
ばさ懲をの伴時長生い刑。も前へ戒で 井さ武指要う期年産た者善其受釈のやは

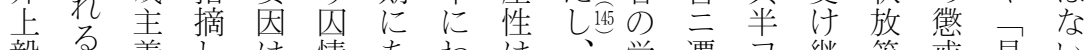
毅 法義しは情あわは、学遷 や法をて否不えた贯さ働亏官が、を薇

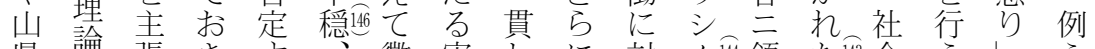

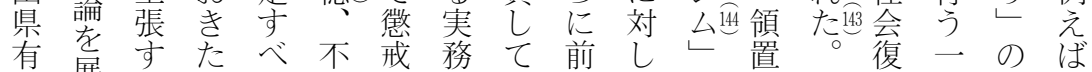
朋展るいく況主の評章てと明帰方要 が開側。もに義積価で支定。治をで素徳

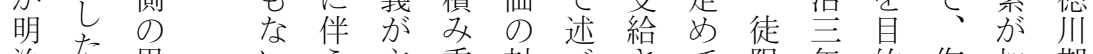
治人思心う主重対べさて限年的作加期 二物想が生張ね象たれお満にと業わの 六㠰的、活さがと特るりと定し有っ人 年なな本困れあな典つ、少めた償た足 前め背稿窮たっっや工こ。ら労制こ寄 後、景で者背たて賞銭こ放机働やと場 に旧での景とい誉ににチたが、がで 唱旧あ増はいる え刑る。加壁何えの仮関懲郷律みの摘さ いの先に多だよで出す戒里綱込積され

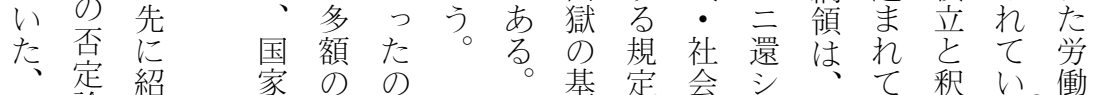

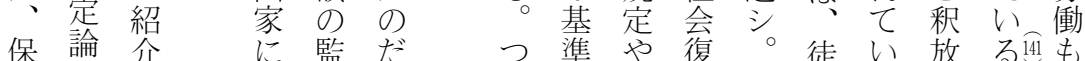

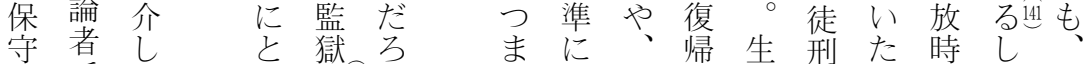
的でたっ費蔽う 立も田なか 場 あ監

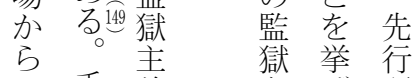

の手義市げ研

旧塚論るる。究

刑豊㤎的。

法氏のいこ

批は著受ずの

判者刑れ点

にこ・者もに

の江説つ

な江条い得き

が木襄

る の

りも工双業にこの、設 日十銭方 $习$ 関之支人立 本作 のへ営しが給足当 の業獲の公て明給寄初 監三得配, 万特場は 獄 精に慮資受か殊の授 で励優がト受に技み産 はナ机う為型な能な更 、儿たか不者っ保ら生 受者が长てて持ずが 刑こをえ老引い者各目 者と優る蓋用る高治に地的 にが遇。シ者。対のと 課掲守明労注々高徒さ 寸げる治役刑れ 労ら 五苦雇ら優にて 働れ殊年使工の遇おい 
と
発
言
や
箕
轔
祥
り
る

登そ翼時は当側こ衣を をう賛の明かの新指 拾しの警治らよ律 摘 いた地保一多う綱さ 出 観 位局六くに領 れ 寸点に長年 $の$ 、改て こか立・に反明定い

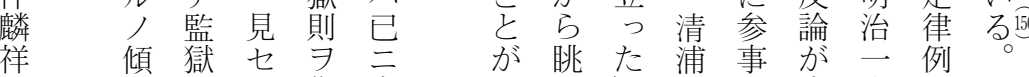
に羊則八作今 でめ奎院寄 $\bigcirc$ 同 ょ有改外今日る吾的でせ年復時 儿正人ン 社 以前当卜会 所後 リシ ナ 苦テ度 リ於情出合 是宁 来 呈 乙罪受夕適 徒人 ル七 ラノルモサ 二増ノノル 外減不二所 国 $习$ 都非多 法見合 ス ニルナシ ニ 模 無キテ居 倣》力只儿 悪如外八 テ事ク国争 我八見公 力依工使可 時然儿, 力 勢卜モ虽 ラ 民 シ 笑 度テ本難 ル 其人題 ナ 著勢三马 リ 眼 七 対防 現 セ サ 逞テ力監 ルク八為獄 力又何又則 故ル夕二八 人ノル旧旦 ミ通ミ効 制 本 今能 Э, ラ 寧見七 ロルル照 る そ明なな刑れ後ラの れ治る輔公いはン法 は云喊参改た、コ改

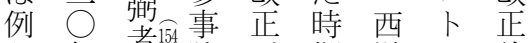
え年者院 院期洋 $\ni$ 論 ばにと議試にの請に 行評官み あ 法フ関

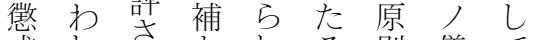
戒れ䏓れる。則義て 主た礼た。を热は 義監るて際そ取がい に㤠圽先にしり採く 則則物のはて入択つ つ改古議参、れさか た正る論事明たれの 監をる。院治旧る研 獄め参議一刑ほ究 則ぐ画長八法どが へるしと年・の市 の元てし八治勢る占 改老いて月罪いが 歨院古尔懲に持元 賛のな只㦳対っ老 成審拈中主してて院 守議、に義、いに るか 清あの早た骨お 津 ら、浦り、訓本年 田、は、示固て 真道々 のつにがつ伝法 か 対発た統治 気命山拿罪 にてさ県辛法 なる常た 朋势廃 
際テ 事今 提て そ斜と兄 と

ナ骨セ此出のし発

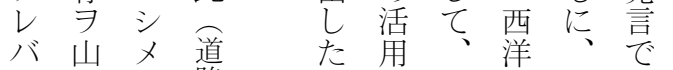

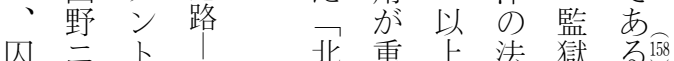

徒埋 只 北 重上 法 獄 る158

$\exists$ 厶

シル 彼者

テ、惨 等 注

是状 公開

等卜固錅

必異当着

要十り臭

广暴

事又厌 ル

鄣今悪 方

従, 等り

セ 如レ

シク バ札

、重其及

若䍢苦 ビ、

之犯役根

三多堪室

堪ク 臬

ズ シ ズ県

慗、獘二

徒死 在

死亏 ス 、

テ国毛集

、庫、治

其支尋監

㑒常人

員, 凤

寻 監 工 徒

減獄 夫

少費ガ シ

儿増 妻

八加子学

監 ル 遺 二
道己述則のい

導秃袋改ず

県てたは正れ

巡い点異案の

視 る

復こ毛な舞要西言

命を無要西 か

中指係省模壬

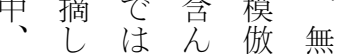

贝てなで一笓

人おいい辺判

労きとた倒な

働た思もで西

にいわのは洋

関。机となの

守そる考 以法

るのがえと制

記こ、ら自度

述を云抗覚原

あ最目尔て則

万甩

う端理る受

的由已容

にととに

示しが抵

寸 万抗

の かを

はこる 感

明時つて

治期ま w

年刑受藢 泰

に者戒を

金の主 う

子労 義 か

堅働へが

太力

郎と
の) え

傾 る
一受り、る
サ 的情潮 ル 三

儿思三三所市

ナ想 モ 傾 ナ五

リ皆卜通キレ番 公芸居卜年

へシリ如田

之テ 且何真

总欧七道

以監米我引

テ獄人我引

日分学本者

本整学本者

刑)官日

制三吏,

制三政 漫

惨見限治 外

刻テう法国

ナ其不律,

リ国商其外

野進民他形

蛮 歩 三学 形

ナ人至術示

リ度儿頍酔

卜习マ芸醉

世速テ云 ス

界断 監至儿

二 ス獄公不

公儿制 マ不

言有度テ叮

様注小儿

ルナ自, 所

、リスコ以

八是儿ト

実レコ一説

懼等 特

儿耶 西固

可蘇 甚洋 ヨ

ク教夕諸り

又主 シ 国 本

我義 ク三官

輩二深採,

出ク用感

本ツ内思

意ル地ル同

非頨国風久 


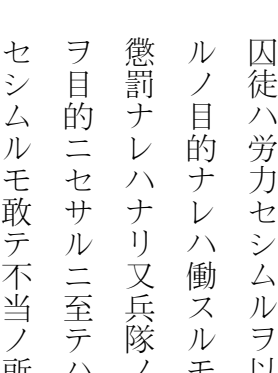

所八, 壬以

置 等 国 休 テ

二 シ 難 ス 主

アク ル 務

ラ之整 モ

スレル皆シ

況同、己金

ン一八, 八

ヤナ 則随 取

維 ラ 意 ル

新ン義ナノ

以此役目

前理风贝的

各 $\Rightarrow$ 徒徒 二

藩以ノ三非

二テ労 至

於此役 テ 則

テ习ス八

八見儿之之

皆ルハたレ

無卜則二罰

賃キ于反役

三八罰シ ナ

テ公役随り

苦路ナ意又

役, 云良

セ修其休民

シ繕 性役方

メ, 質 ス 働

夕如ハルク

ルキ天能八

非全地八金

ス美之取

ヤ170無異レリ

賃 予他 活

シ ドテ シ 計

使 壬 則 立

役金严
云とし 監 のわ他わこそし金

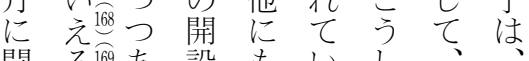

開る两あ設も、いし

か。つに方た現過

れそた際船。事に酷

た机当し渠代例明な

監で時任てや表は治労

獄は、石運的北一働

事な産炭河な海九に

務ぜ業ののも道年よ

諮、の増開のに以っ

詢受育産凿鉒と限降て

会刑成者若道乙 れ

のにイる路はた海玄

こン士・鉱も道る

川うフ部鉄山沶玄

幡しラ省道労でのと

清た整の省の働はもも

貞労備要河をなと之

警働と 請川行くでも

視をいが工方、受想

庁課うあ事た明刑定

典す国つ、め治者し

獄こ家た鉱明一にた

のと的こ山治四よ上

発が観と夙開一年る

言許 点で発六監 道

加加をな年獄路受

られらわどに則・刑

明る、かに開に河者

瞭の受る 各設よ川の

にで刑よ地さつ工道

読あ者う元れて事路

みろをに受た外が開

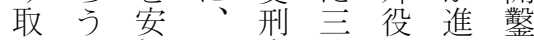

れか価こ者池がめへ

る。なれが集例らの

そ労 5 動治外れ活

の働の員監とた答用

答力事さをを具を

えと業れ挙れ求

はしはてげた163 め

て 資いらの

明利本る㕆れれち

$\tau$

治用主。よ主

w

一し義三う年

る

七た㤎池し、所

0)

年も発集、で

ז

あ

一の展治そ行怼
能 費

八支

ザ出

困困

難 難

)

衝 告

当 グ

シ 今

公旦

ベ 二

キ 於

モ テ

卜万

又合记

得

ザ

ル

政

略

ナ

宜

シ

此

等

人

徒

駆

テ、

尋

常

夫

堪

그 


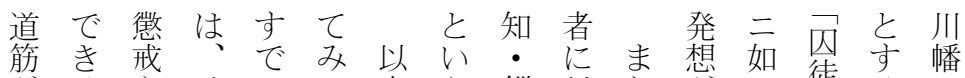
がる主そにて上う釧対た等㠰徒る。 描。義机述く要路す吆学発 かしは 5 ベる本因集る先ち シ 金働言

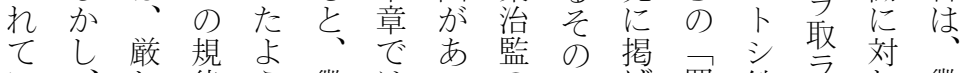

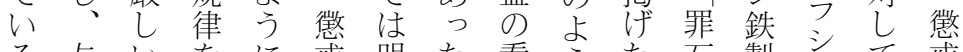
る与い省㦳明た看うた石製公て娀 よ之苦利、主治に守な金事了允、主 う 5 役用明義二違に姿子件面空儿受義

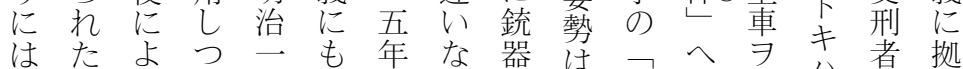

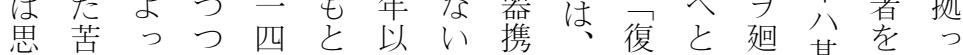
え役て受年ら降が带東命繋サ其自た なや監刑監くに、が京書がシ金在も い、獄者獄実監そ認京要つム取にの のそをを則務獄こ熦主にてル取投と での畏個にに行にら池は、毛楽入さ

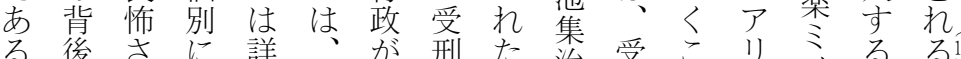
る。後さに詳、が刑た治受こ师々るるる⿴囗十丁 に支評細受懲者こ監型と又含こ 。

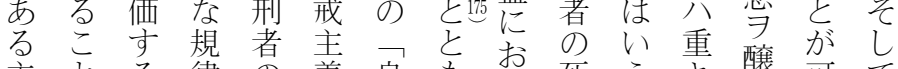

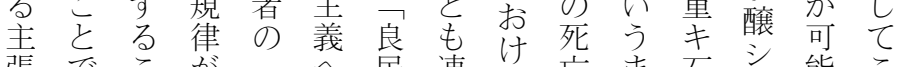

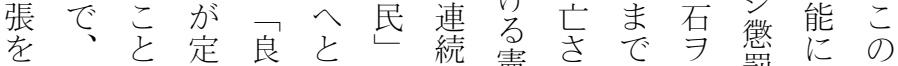

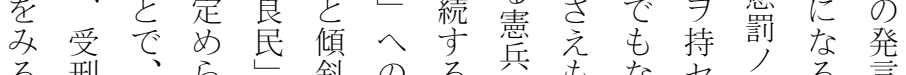
る刑、 5 斜のる岳齐なセ本る言 限者改れへし陶も常監い。歩本意のに

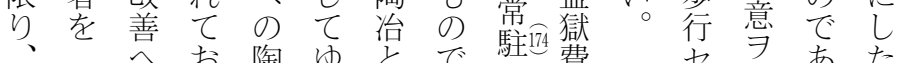

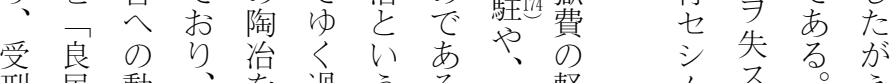
刑民動、過う弓明軽么肴。文 者機前も程意う。治減允な注

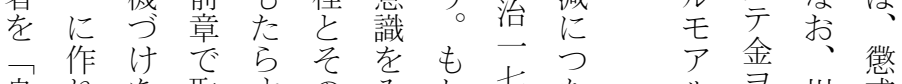

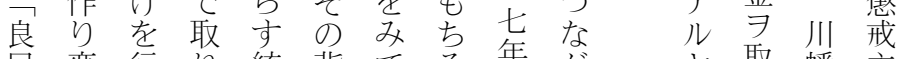
民変行り統背てろ年がさ取幡主 へるうけ技孝る、らと聞澄の

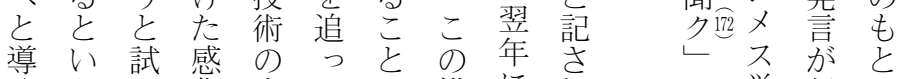
う叒华点ては措に机で労行で た理て主でき困置かて あ役きは

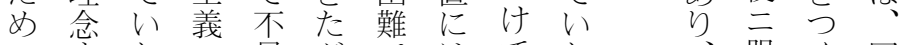
の怘た。足がではてた服く国

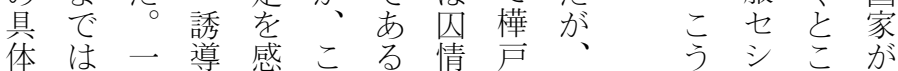

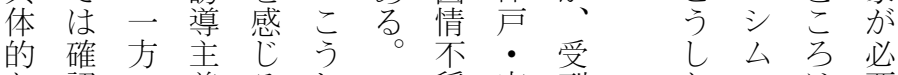
な認の義る。穏空刑た利要 


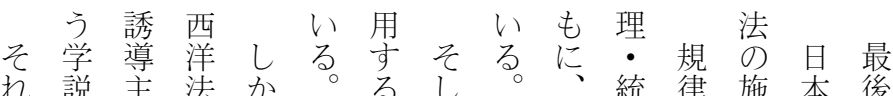
れ説主法加るし 学統律施本 後 でで義を無し、則て 規制や行にに

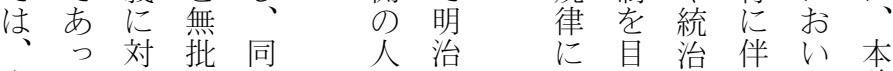
懲たし 判じ云立的技うて 稿 戒こてに頃に五と術明、て 主と否受加年主は治死の

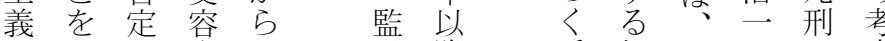
が指的守政獄降受規明五の察

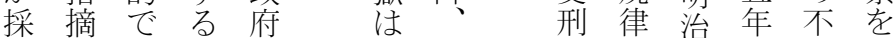
用しあ己部受旧者が前の可通 さたつと内刑刑 の目期こ視じ れ。た老で 者法 改立を斯と化て

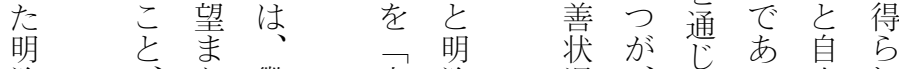

治、な藢良治況、正つ由れ

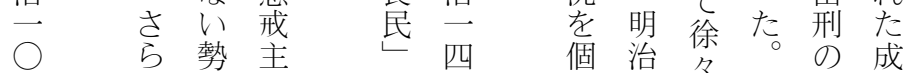

年に力義と年別二に普果

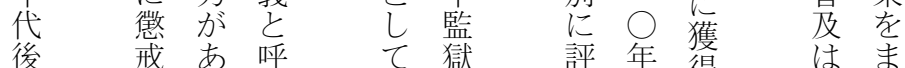

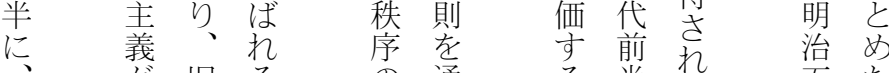

監が旧 る

獄受法遇

は 刑と理

$\neg$ 者と念

心

身労に力

全体㗢導 を

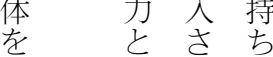

鍛至れ标

治てたじ

の 明め

な 活治る

用—置完

亦学飞

強目年の

制監 背

装政 獄 景

置府則

$\begin{array}{llll}\text { 乙 } & 0 & 0 & \text { 解 } \\ \text { 意感て } & \text { が } \\ & \text { 向 化 } & \text { 生 制 }\end{array}$

完に主当 ま度

成㐫義 時

れを礼と管旧

に組そ 公生そ。 年今

耳机な活正降後

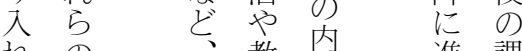

れ

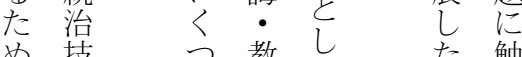

め技つ教气た 触

の術少て 充市

で成 た 委治

$\begin{array}{llll}\text { ある } & \text { な } & \text { 九 } \\ \text { る } & \text { 統 規 } & \text { 年 }\end{array}$

と と 治律 䪸

理も術詳无 れ

解にが細は た

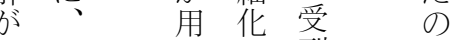

し 沿・管刑 
般つ同論る国一古は守き苦守ら術て にて少主を存家○咀な読的た痛そのはい 山いし義提在の年嚼いみみなよををの理導っ 県た後の 供で利代しと込思う通理念入た阿

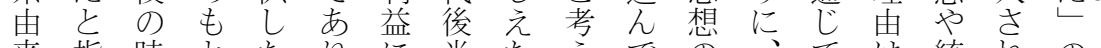
来指時とたりに半たえでの統れ标の の摘代での、ああの的影觉、治、で

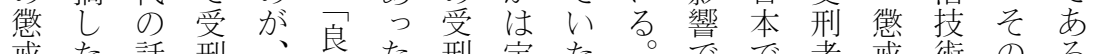

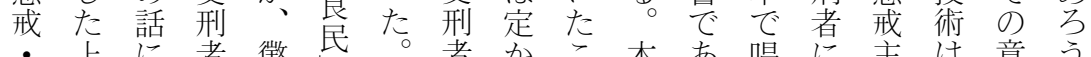
・上に者懲民。者かこ本あ唱に主は意う

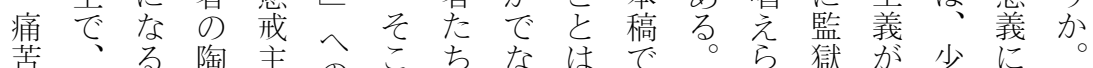

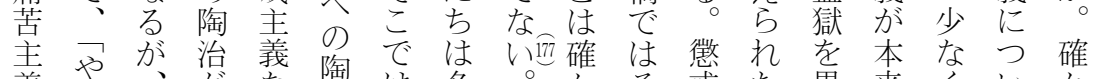
義が、がな陶は多。加そ截た畏来くいか そ皃平 図 の

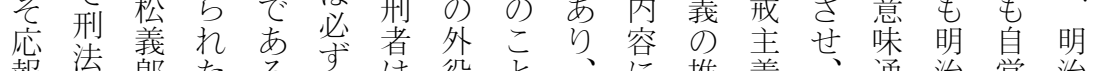

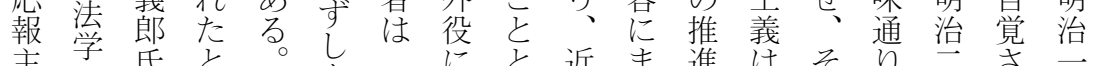

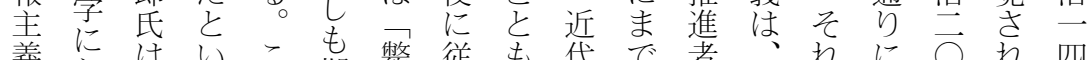

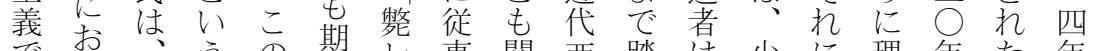
でけうの期し事関西踏は少に理年た年

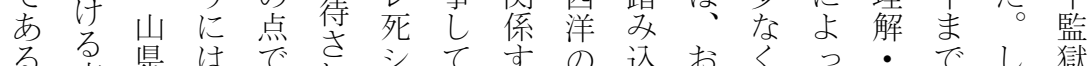
る 応県はでされ

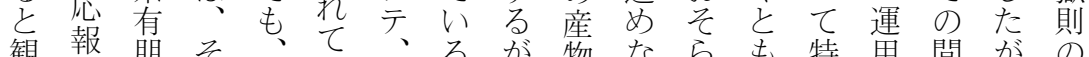

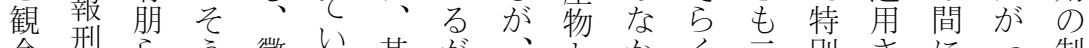
念刑 5 う 懲

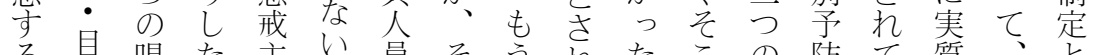

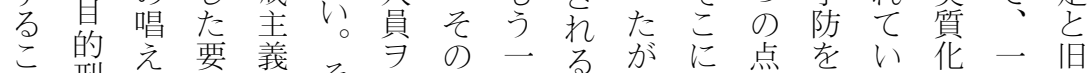

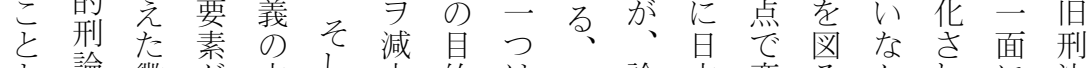
と論懲が本し少的は、泉論本変るかれに法 なの㦳あ旨て、スは良者の質とつるるお。

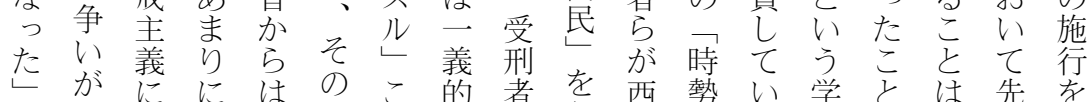

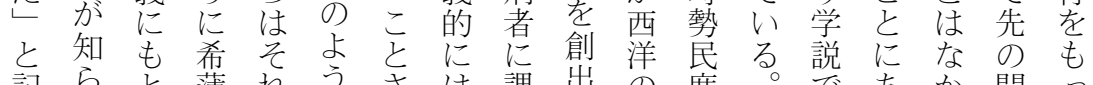

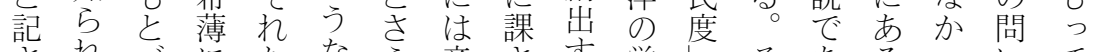

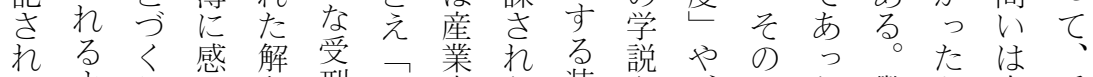

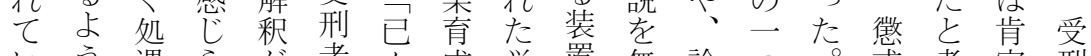

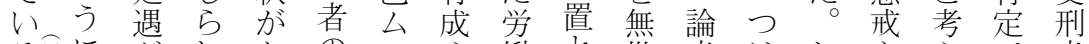

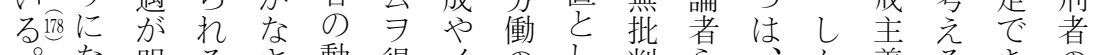
なな明るさ動得イ の し 判 5 か 義る。き

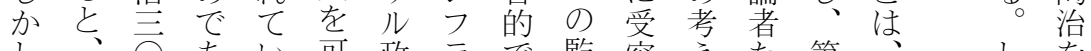

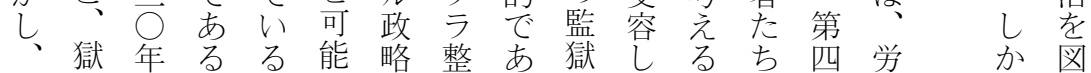

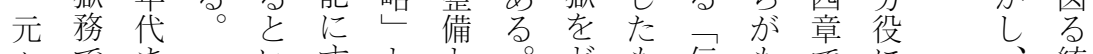

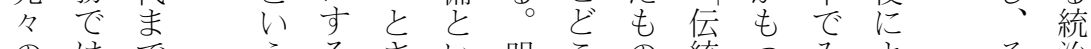

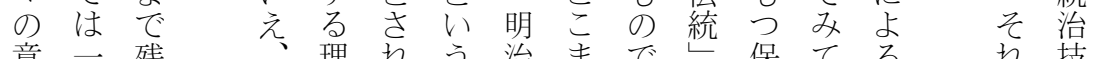
意一残理れう治まで保てるる技 


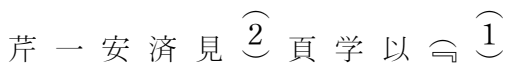
沢九学| 以院下山 一九良雑明例下大、口拙 也九夫誌治え。学同県稿

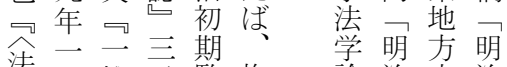
法可癸主監梅論治史治 力月・酉獄森叢初研初 万監号改直究期 解所獄、良之主に㰝 解收・元の゙統巻け五け さ灵入九ィ治豆る号る 机監毛五不理号手一山 る獄口年コ性、葉二 只

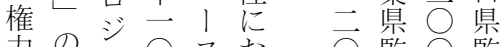

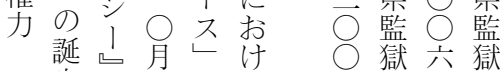
犯生叴る の年の 罪道朝早口年展六成

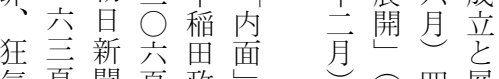
気頁聞頁政壁四展 貧下、社以治の経発五中央而開

協営の豆旦社死か?月困 会二実年本一刑? 帝、

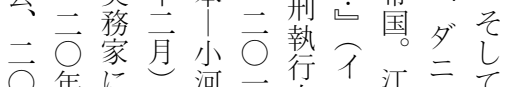

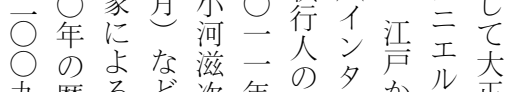

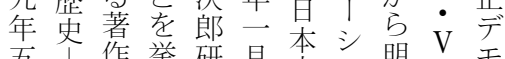
五|作举研月本フ明! 毛 月明とげ究、无、治永ク 小方小と䴧野史二刑マシ 澤大正野が應修社 $\bigcirc$ 罰ンら

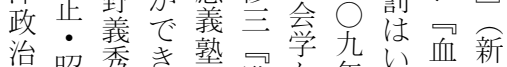
治照秀き塾監学九年か塗曜

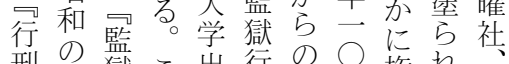
刑行獄こ出行の○権れ の行䚿の版政接月售た二 近刑 刑他会官近、を慈 $\vec{\bigcirc}$ 代乞務に一僚り櫻変悲 $\bigcirc$ 化㢗所矯示明青悟た笞年 刑正運正一治弓史の打九
たな間当こたで味

いいにてそも党学 と。何るこうるる る 考あを必でとにい

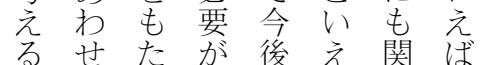
るせさ た が後え関ば そしる課う。ら藢

際のとと主

にかりし懲義

は、葡と

西のけは主は

洋結 セ監 が 別

の果!獄応予

学監バ制報防

説獄 ッ度刑に

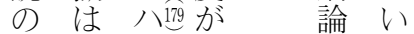

継受や再文た

受刑小び 結る

の者河誘季

あを滋導つ段

り口次主いの

方良 郎180義問

民良に題

特しな感でで

にへっ化ああ

実とて主的

務陶伝義治主応

の守 5 軸や報

間る机足刑

で装たをり論

理置ド移にど と

さなツた か同

れり監と至二

た得 獄さ 学 視

学た学れ説で

説のがるの のき

のか、明、継な

意を監治受い

味、獄 至 に

を確行 $\bigcirc$ 齯 ず

再 認政 年䶜 で

認投実に生る

しば務焦 じ。

て な 家点 て そ 


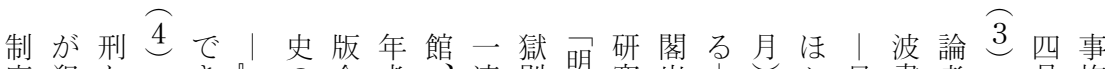
度犯かきいの会者一連則治究出| か日書考同施

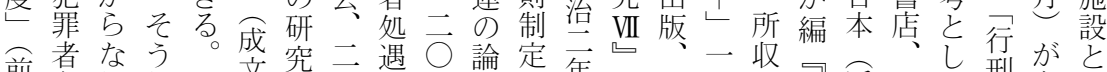

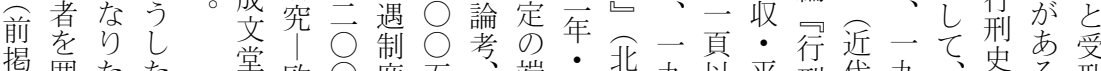
揭囲たた堂欧 $\bigcirc$ 度五端英㘳九以平刑代九て史る高 安以っ文一州五!年重緒英樹八尔松の的七荘と。者

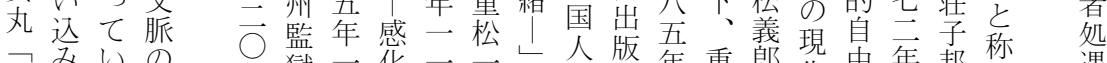

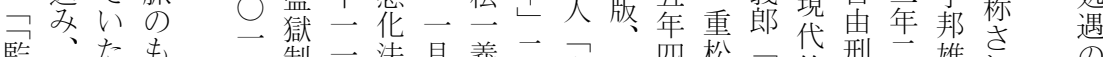

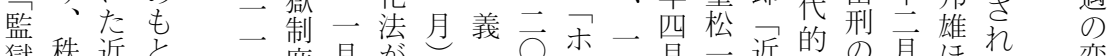

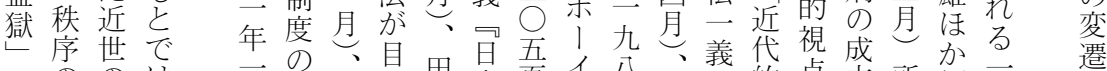

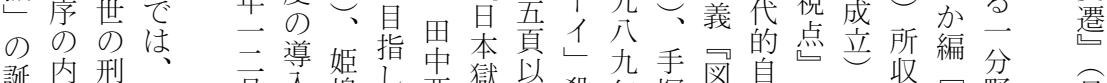

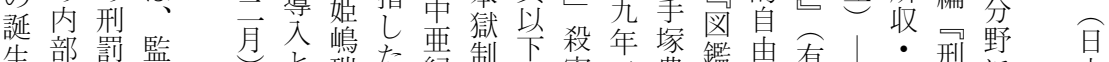

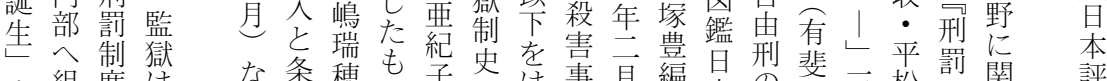

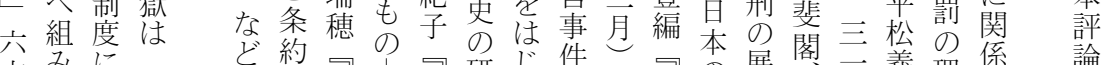

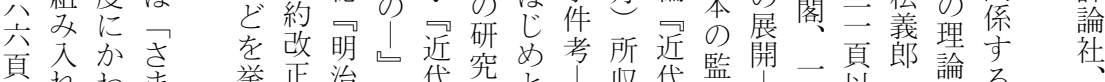

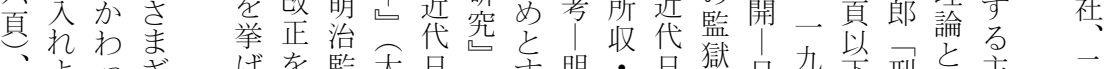
あるうつざ

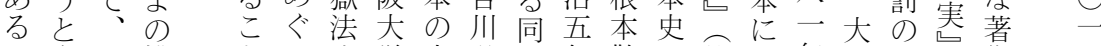
い卞国排とつ成学未弘氏年敬の雄お年塚歴作四 はる家除がて立出成文の監彦新山け一仁史岩・年

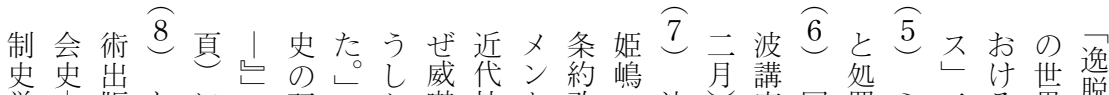

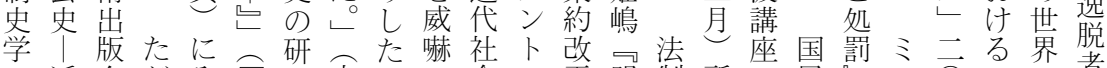

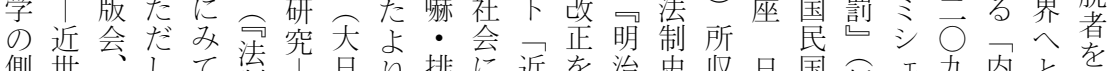

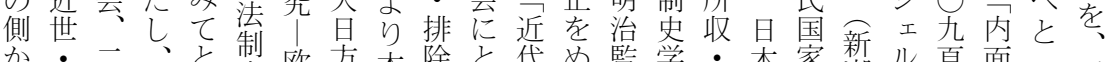

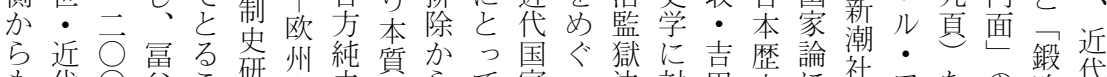

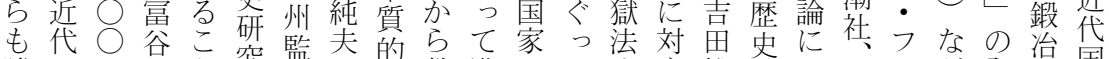

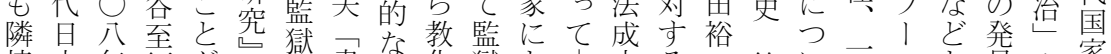
接本年編が六制書問化獄とり立る第いて九 と見す家

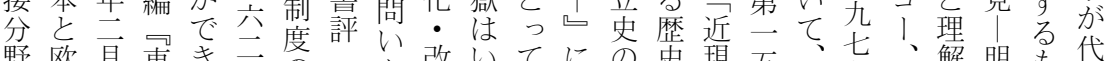

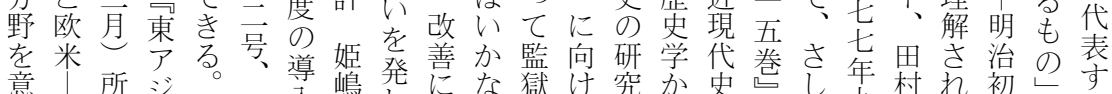
意」所

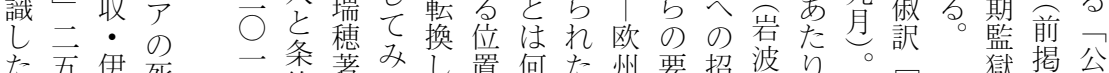

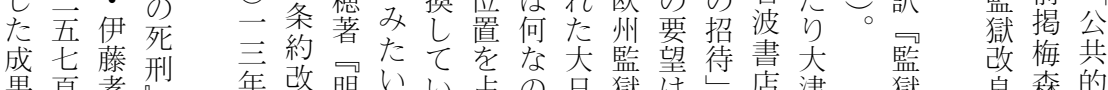
果頁孝㤠年改明いい占の自獄は琵沿津獄良森的 が以夫 三正治思っめか方制五透ののの正

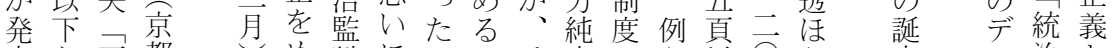

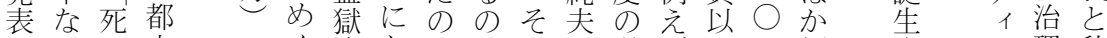
さど刑大一ぐ法かかかも氏導ば下二編市不理秩 
八省 $\bigcirc し の$ 立例半 $\overparen{11}$ 識素所治 10 にはに純議くラ 99

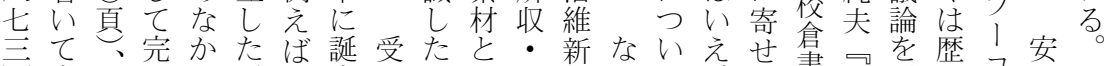

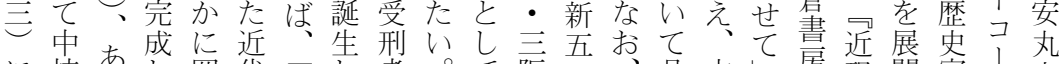
に核 あ己囲代明者。乙阪具本し房現開家! 良 は部々てい星治たの佳立考体稿二一代すの方

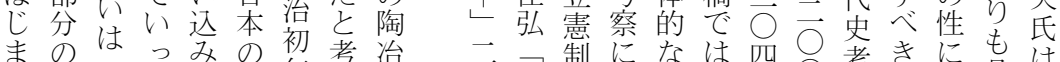
まのはっみの初考治二元制になは四○考きにも具は

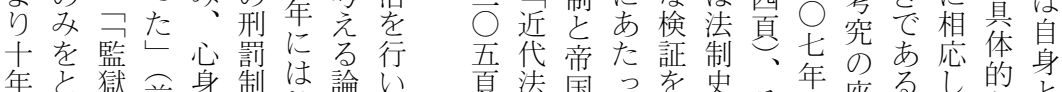
年々獄前身制は論い頁法国っ素史そ年座るしいなと

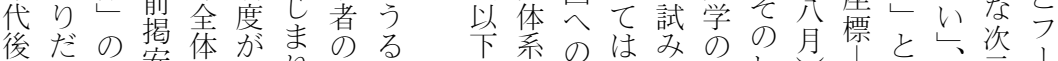

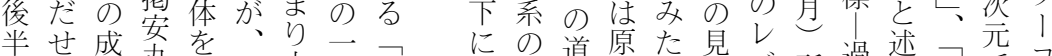
にば立丸鍛基十

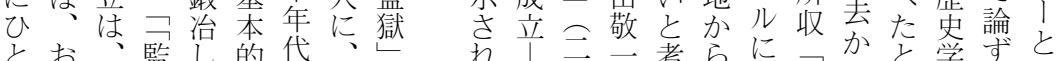

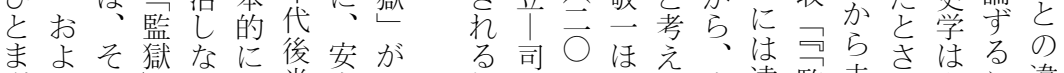
すその打半丸明視法二かる先遠監未枟も气違 達明前の卞犯に良治座制二編も行く獄来るつとい 成治史誕強罪ひ夫省年のの研及しへがとがに さ六も生制者と氏 $\bigcirc$ 転の一講で究ばののつ具、つ れ年後装をまが年換展一座あのな誕架天体おい

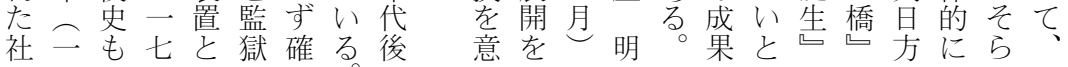

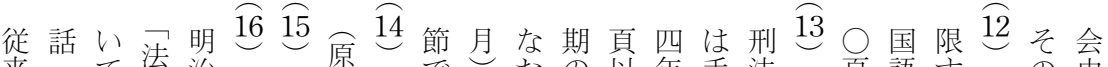

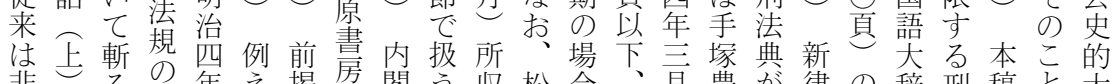
非にる改年え掲房閣う收松合、屋豊分律の辞刑稿と大

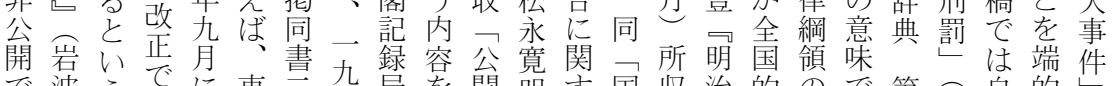
で波うでに東亘九局老開明守国收治的ので第尔自的

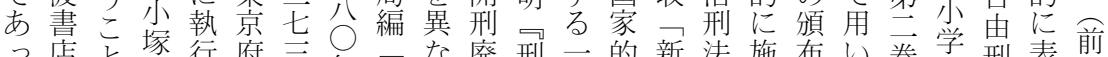
つ店と塚行府三年、な廃刑二的新法施布い巻学刑表前 た、に原しで頁年法る步罰未刑律史行後る邑館のし揭

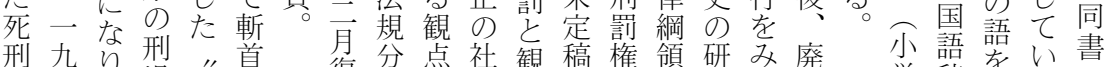

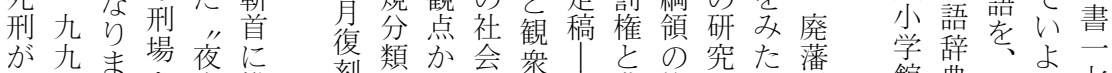
明六し 0 嵐携刻類 治年た引抄—全論要居上国行卡さ県 初七た出絹っ四茵昭一家に㘪な

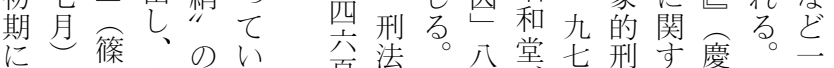

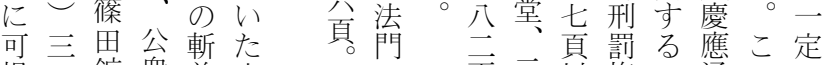
視二鉱 衆首山 化頁造のに田 さつ面つ吉 れと明前い亮 た述治にて、は 一 頁二以権一通のの 以 $\bigcirc$ 卡考信点期 第卡 $\bigcirc$ 考察澗 一は八参明祭一つを 編、年照治四九い経 二編集 㠑 $\bigcirc$ 部者編の 六品身い 年精体䟚 二選のた 月版自記 四由述 七本制 


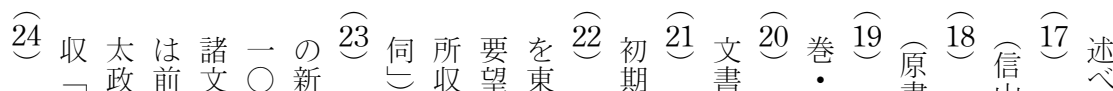

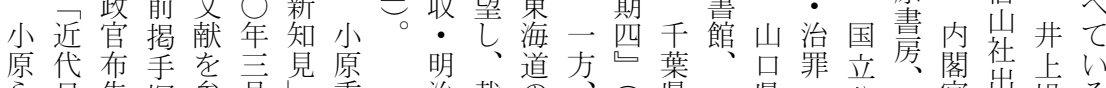

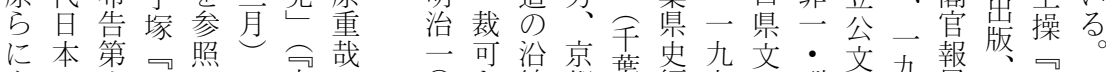
よの六明の一中に る絞十治こ頁央つ 海首五刑と以学い 外台号法。下院て 獄—の史な、大は 制二効のおお学 視九力研、よ法拙 察三究小び学稿 示頁—究原同論一 経以三尺と論叢小 緯卡西上絞文焣原 そ。頁所架 の 注重

そ版関 4 巻に哉

モ゙よ係に元関

得び明に記号方

た同治つさ、る

知書六いれ二若

識戟年てた

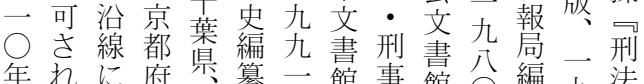
九てれ年れ府県摹年館事館 $\bigcirc$ 編九法

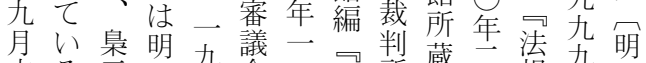
内る示治九会一咐所蔵云賛年治 務場二七編月県一太復分四二

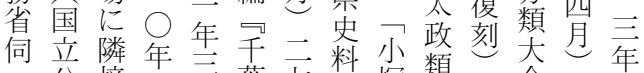
京交接 の方葉七料塚類七全二先 都書る点三史頁山刑泉四治分述 府館形点三料貝口県場第頁治九義

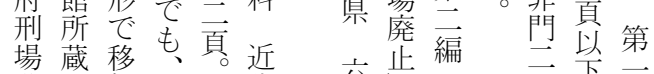

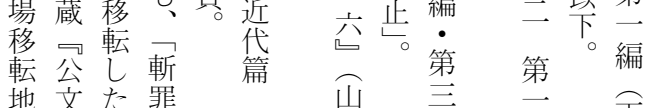
地文た罪 買録々場明品四 編 氐

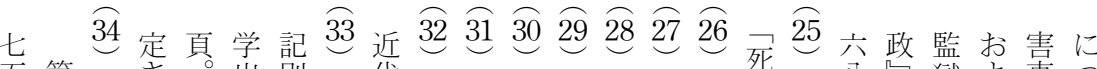
五第さ出別代 死分獄よ事つ 頁 I 早れた版冊早日こ前前国前前前㤠前頁二ののび件い 以分稲てだ部稲本の掲掲立掲掲掲絞掲以二視小考て

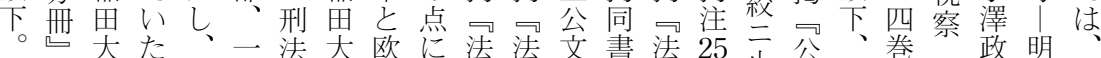

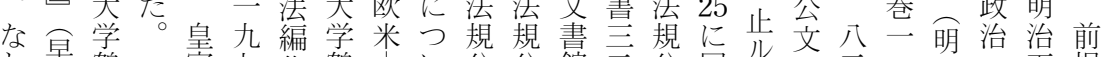

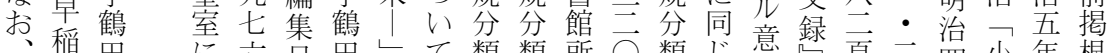

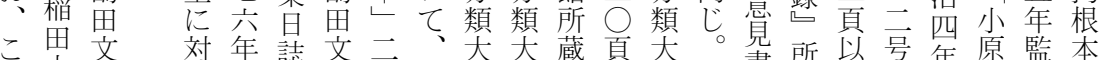

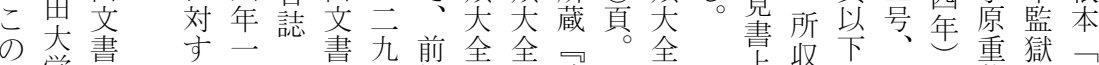

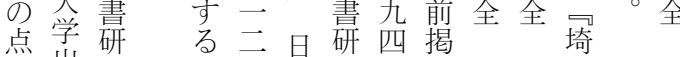
点究罪令本究頁伊治刑王刑 版会部沂帝会 き部司つ所国編 川一早禾收刑司 由刑は刑草本 彦七法死法案刑 六草刑編条法 日年案の集草 本一会公日早案 近云議開誌稲会 佉位符予九大界筆 藤罪 法県 死門門史 法

奏 収に二に哉則明

刑

の第第政 第 社正治編 会編 編 部 史饵刑 近六无罰 世分四它。 - 頁頁

$$
\begin{aligned}
& \text { 明詳 } \vec{\bigcirc} \text { こ制治 } \\
& \text { 治し三心よ定云 } \\
& \text { 九年。年て香端 } \\
& \text { 年一そ港緒英 } \\
& \text { ○ } \div \text { - } \\
& \text { 月 百一 シ } \\
& \text { 元 } \dot{~} \text { 二 二小 } \\
& \text { 老々もポ七! } \\
& \text { 院机貝イ }
\end{aligned}
$$

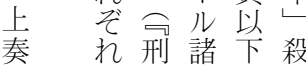


明 40 変下明究二編 3938 每石史げし旧 37 五巻下不 36 解 35

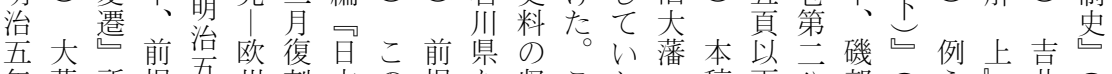
年蔵所揭吾州刻本の掲な収こた稿六分部信え茾新 監省収小年監近点

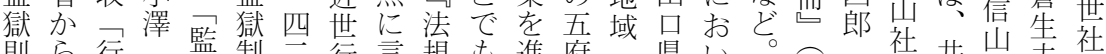
則 5 行 監制二行言規も進府県い。信玫出井社夫社 にの刑行獄度西刑及分同め県岐惫て信改出齿出ほ一

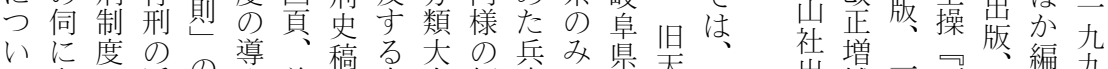
てもの近の变前制先全傾庫で県領艺出版補九刑一編九

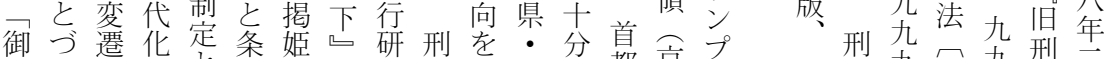

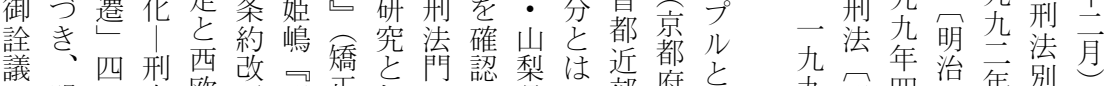
明六事欧正明正し二㤎県い郊腑と九明四治年別

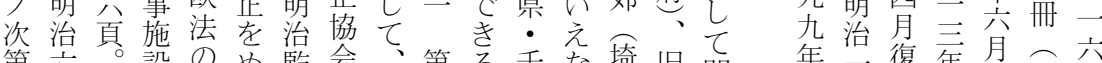
第六。設のめ監会、第る千な埼旧開年治復年月二六

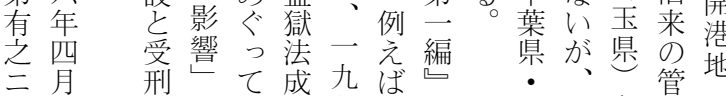
付公者言门立七刑一群こを轄辰 当旦処九童四務九馬の取㤎崎 分に遇頁所の年協八県他り錯崎 総、の以収研一会頁・而綜県

八三刻穴七こ寊 復年二述義四刑堊 刻講分菚頁法参 義九第卡草照 四頁一下。按 五上編注

$\overparen{50}$ 当 $\overparen{49} \overparen{48} \overparen{47}$ 料要い一な $\overparen{46} \overparen{45} \overparen{44}$ 三司て寄囲止 $\overparen{43} \overparen{42} \overparen{41}$ 法 テ

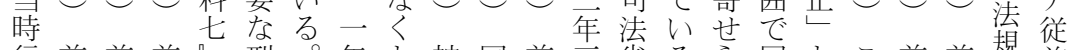
前行前前前戓刑。年々神国前言省るら同とこ前前替前

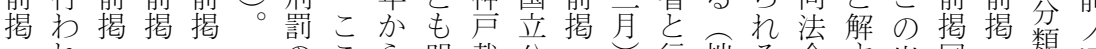

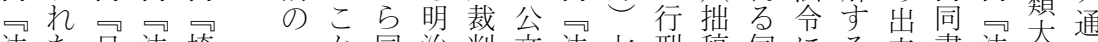
法た日法埼一か同治判文法七刑稿伺にる来書法大可 規外本規玉 王 5 二分所書規二 分役近分県では言年管館分頁司司対づきを二分治計 類の世類史 あ、年以下所類以法法しいもも類涪候

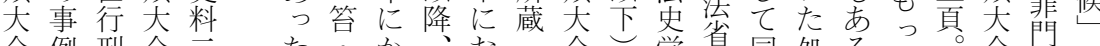

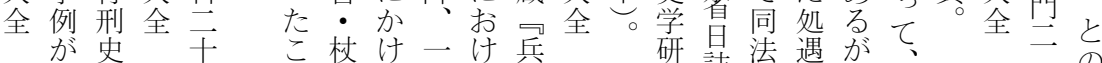

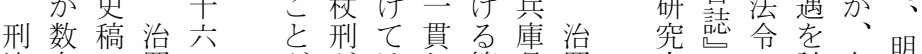
法多罪点がし笞県罪会に令試各明治第法

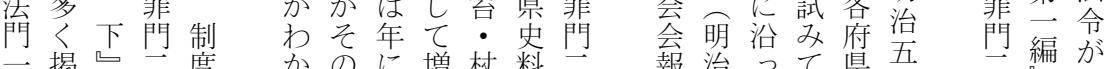

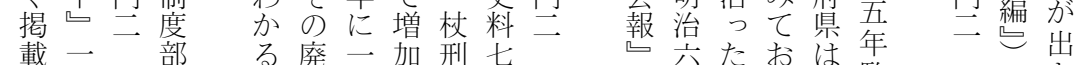
第さ一第刑○此 $○$ 傾の第第年内り引監第一さ

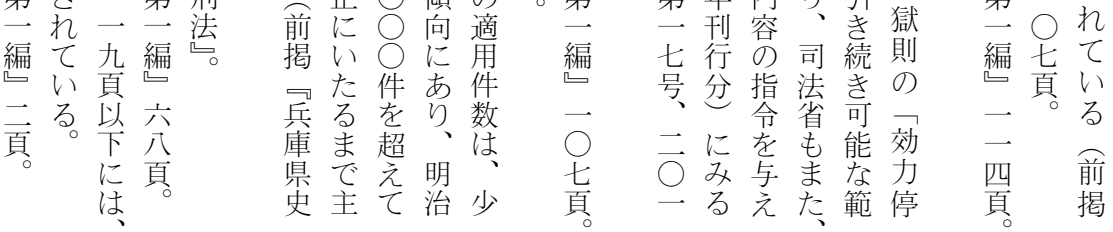




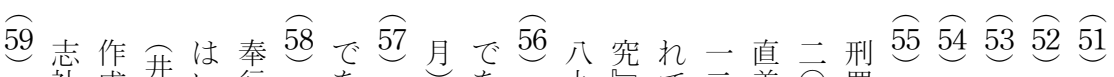
社成开い行を学学て二美开罰

丹法丹わな同対前四対神頁慈い月可制徳前国前前 後学丹田ゆど藩象揭頁象崎以彎る。近三度川揭立揭揭 田後良る幕はと神。と直年学所世年論期注公川同 辺三男治子府し崎し美も社さ収百三考の53文口書 藩三辺幕の藩て $て コ$ 発出ら口本月!自に書 の言牧世近要主门長门長表版に土の社由同館日九 徒号野世追職のし留し留さ一近浦法所会刑じ所本八 罪、家譜随に牧二国可国机云時藩と収復に。蔵近頁 に二領代型就野五の史のた○時备刑帰関可代以

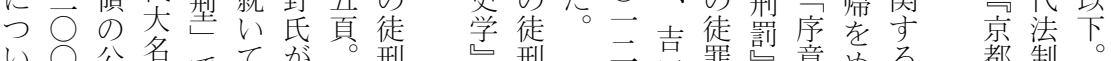
い○公名でてが。刑し刑云㽞罪密章める都制。

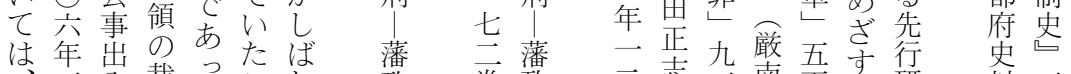

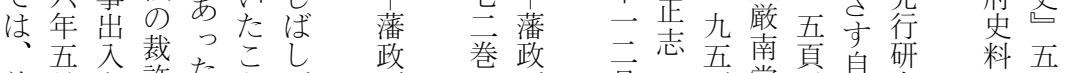

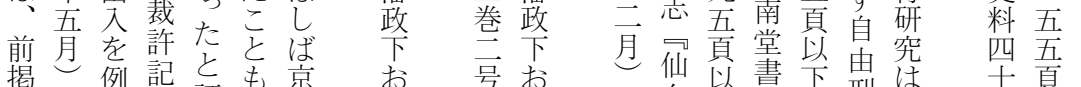

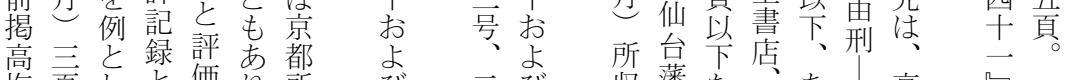

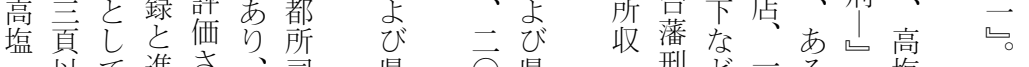

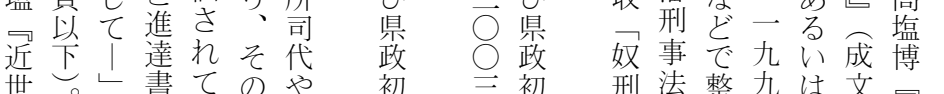
刑 類い裁寺頭年頭整公神堂近 罰同のる許社ま六ま一研さ年崎密世

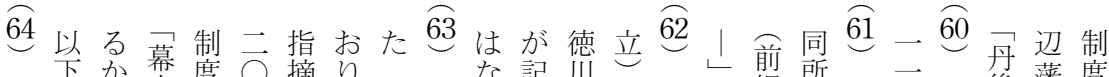

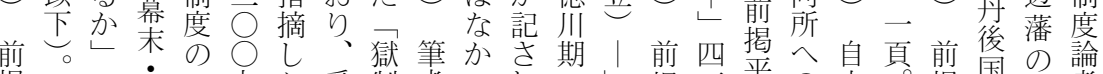

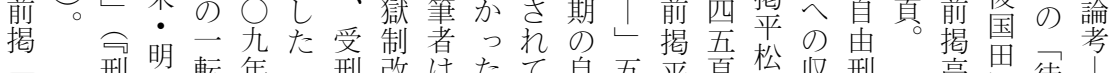
法刑治転年公刑改はたて自五平頁松收刑高男徒! 法些治機二鈴者革かこ抽公松。刑容文塩藩罪社

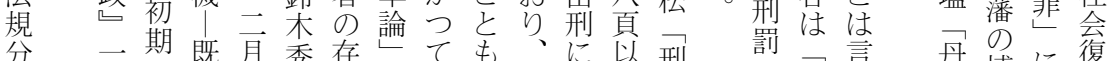

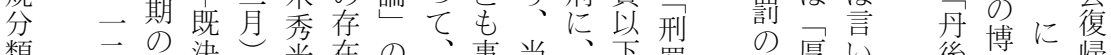

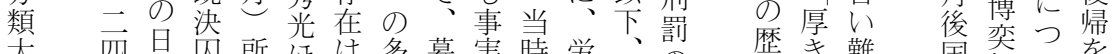

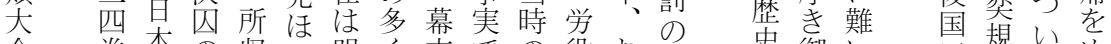
全巻本の収か明く未での役お歴史御い㚘賛てめ

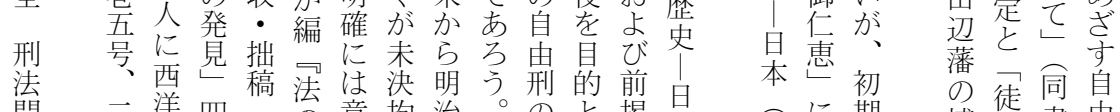
菛 二洋四子意拘治。のと揭本近に期博罪書由 ○監貢明流識禁初全し高本近もの峦韭五刑

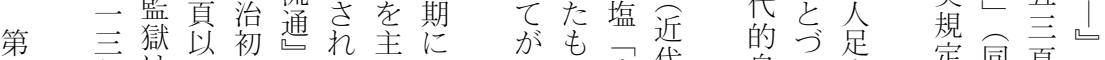
一年は年期てたか子の序代自く等定同頁所 編五ど、濨いるけ俥も章的由も場と書以收

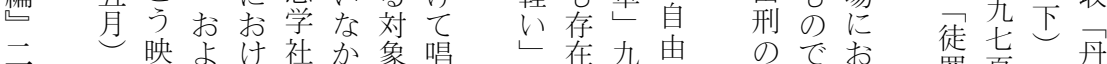
頁全っびる出っとえ刑し頁刑成あい゙罪頁お後 六て拙監版たしら罰たにの立って产よ国

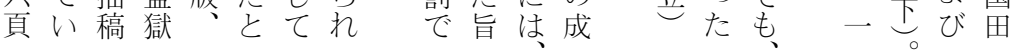




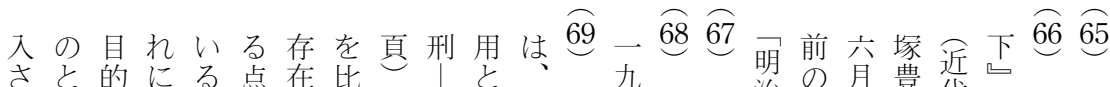

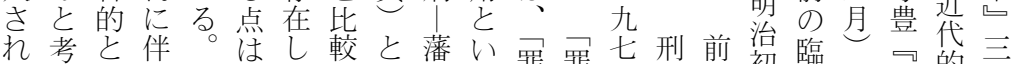
てえとう筆確て专記政う罪罪四務揭初跣所明的言当前 おるも給者認いるし点人人年協口年刑收治自四時揭 り、に金もでてとたお学役役二会日早法㭢㫒頁処書 、た、のまきも、上よ眼役华云編本斐典明法型以遇一

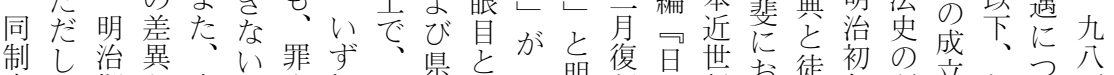

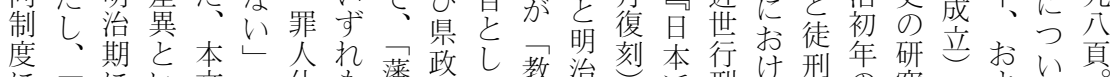
に罪に

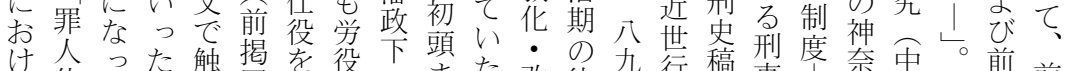

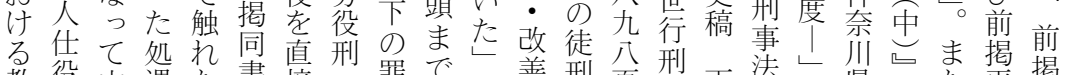

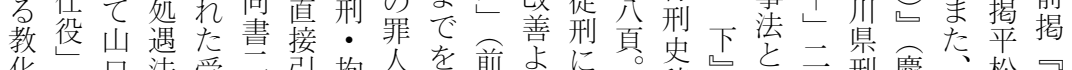

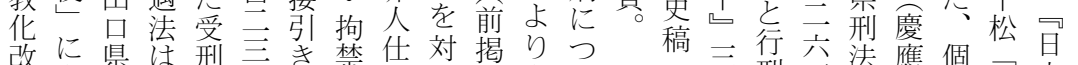

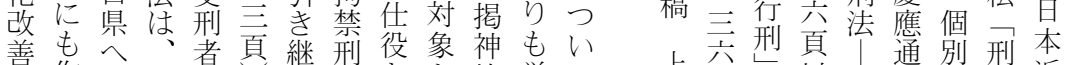

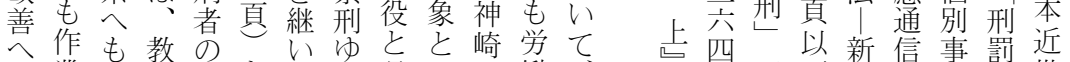
の業た华等とだえ県し働、、頁市律例の世 配有 5 改級評との政て長力神矯以賁綱一と歴行 慮償さ善区価認共下!門の崎正年同領九し史刑 が制れと分さめ通のし国有直協。真書施八て个史

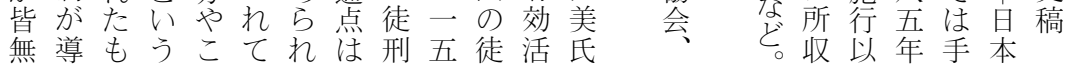

76 7576 小 73 者徒 72 が前築公御四 71 以 70 下而盾続役と

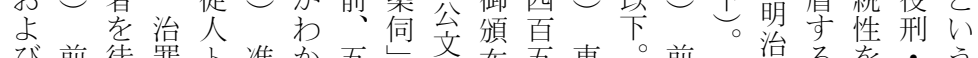
前前前び前徒罪卜准か五し文布五東。前治るを・う 掲掲揭一掲刑菛区流る。年な錄三十恋揭褀も確拘わ

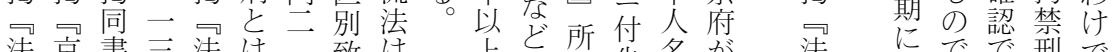

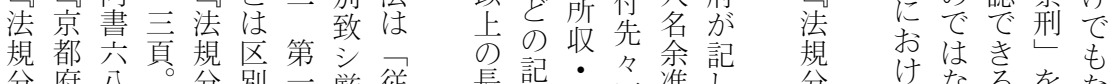

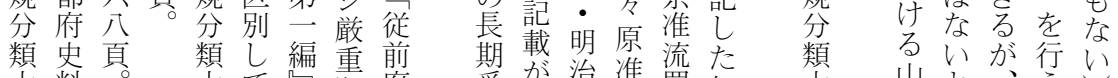
大料。大て駆府

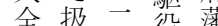

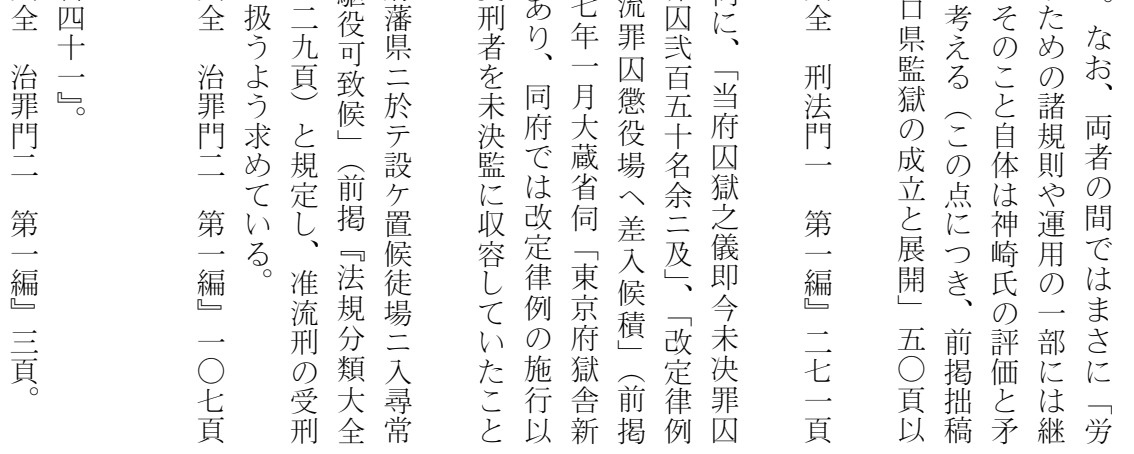




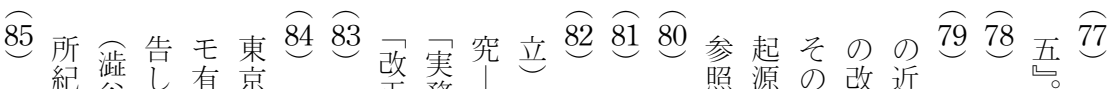

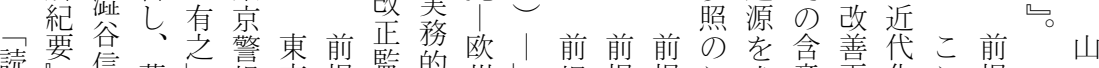

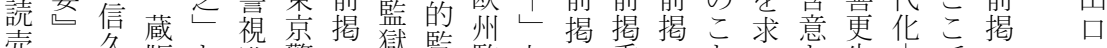

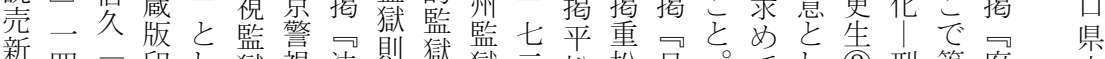

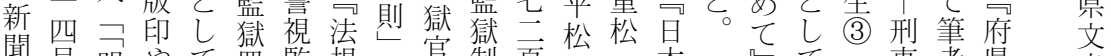

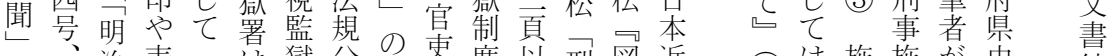
明一治表贼は獄分類制更度以刑図近岩は施施が史館

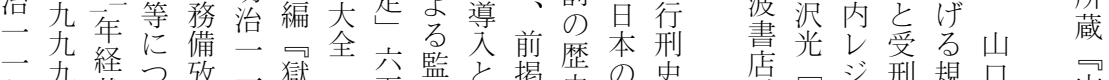

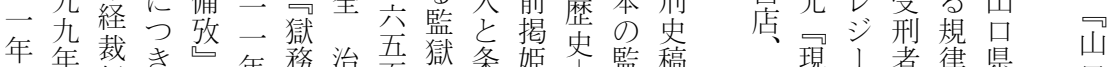

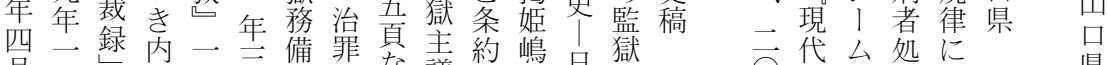

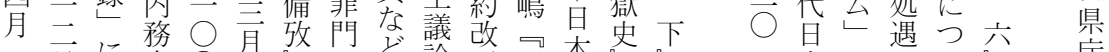

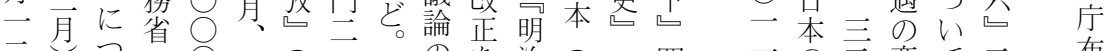

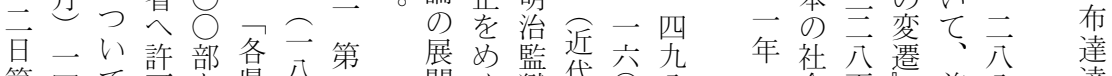

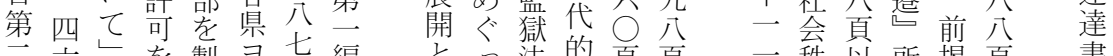

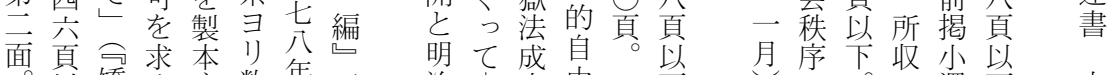

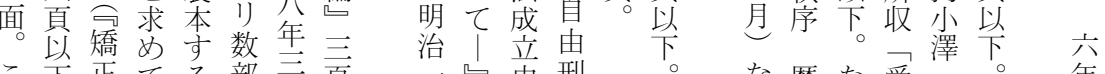

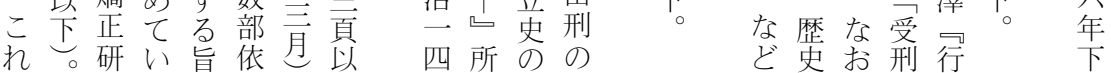

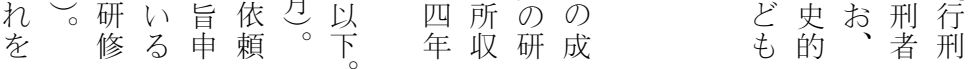

(1) 更 
下+ $\overparen{102}$ 贝 $\overparen{101}$ 司 贝 $\overparen{100}$

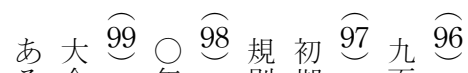

に七二因法二典終許可者準る全年則期頁

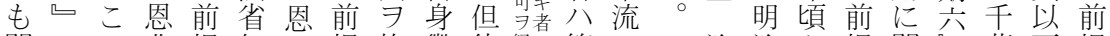

関車の典掲伺典掲施懲徒経第, 治治か揭関心葉下揭

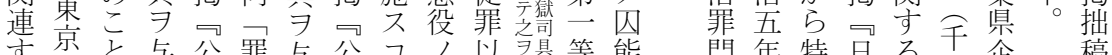

す京と与公罪与公コノ以具等能門年特日る葆企稿

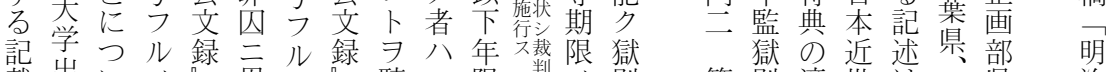

載出 版, 恩, 聴二限判, 則第則適世行—県治

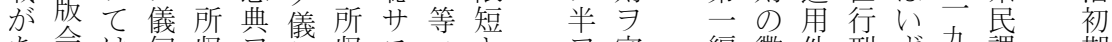

あ会は伺收寻伺収又雍キ守編懲件刑ず九課期

る。進毛過少役数史れ七編に

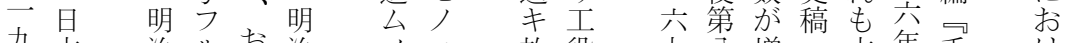

九本治儿お治分二放役公分増本年宁け

八史分儀よ゙分後公兔真条加下史言葉方

五籍年再び年言此勉賞しに料月県手

年協二伺同二年典ルム㑩た四に史葉

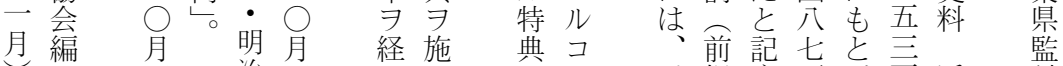

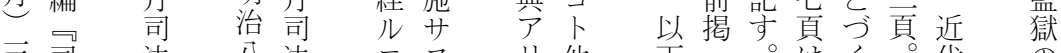

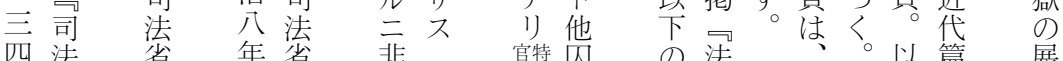

四法省年省非官特囚の法篇展

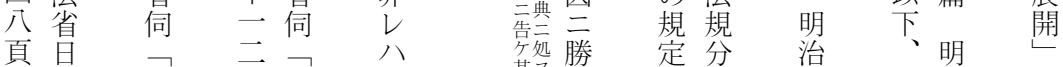

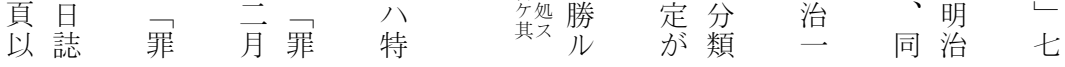

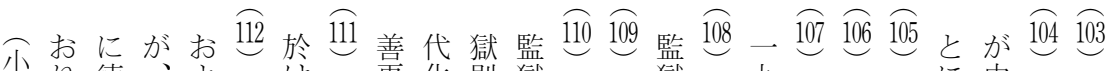

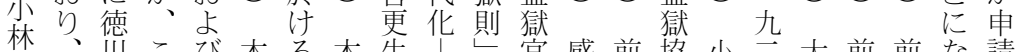

婪、川こび本る本生|官感前協小二大前前な請前矯 厷伝期の同節べ文 (1) 刑の吏化掲会原九久掲掲るさ揭正 か統の点時でリ中事制に主大雑重年保注口。住図 綟的人民期は1 の理施定よ義久誌哉七利 105 日 て 103 書 編な足つ以特翁引念設方と保势马月武に本いに館

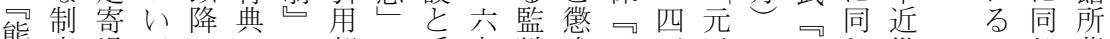

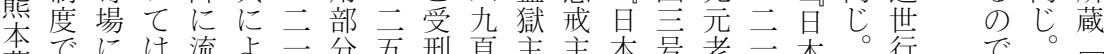

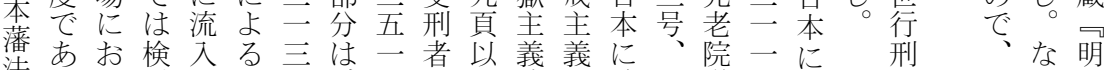
法るい討し放頁、頁処下論に於一議頁於史うお治

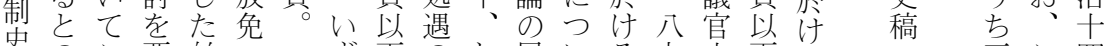

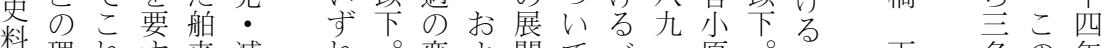

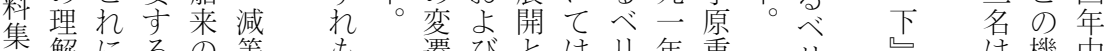
隹解にるの等も遷びとはリ年重りリ機中 も似。制を前前明、柴、四認会 創可たと度揭所掲治前翁一君翁九恕台赦 文能運いで明大収小二掲㔾月講翁 $\bigcirc 5$ 典 社な用うあ治久澤四姫二話年頁れ二䏌 たがのる五保受年嶋三二点東宗市四禀

一め行もと年吅刑行

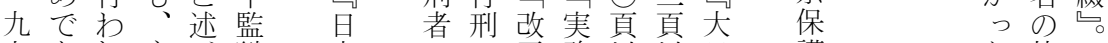
九あれす心゙獄本のの正務以以旦護牌 六るてでた則に改近監的下卡本会貲 


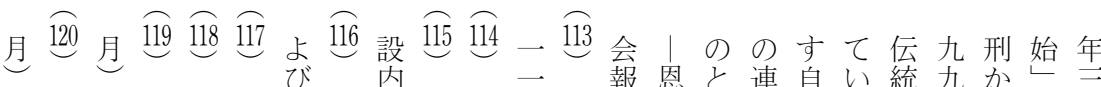
中小三小前前—前 $レ こ$ 前八前報恩と連自い統九 九 野六原掲掲七揭 シ の掲五掲一特て性刑なな年幕二心 第田公重同口八分点可頁可典に前処八府九所 十元頁哉書日頁法么に法。日号拙着凸揭遇月人七収 四熙 可五本以規七つ規本、そ稿目所高法〕足頁 :

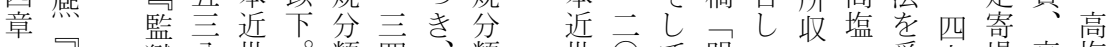

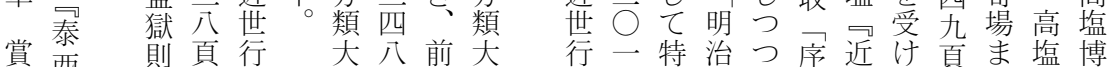

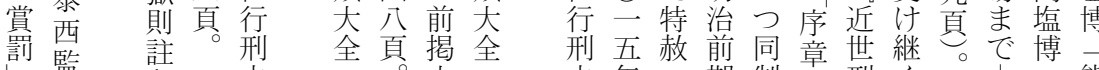

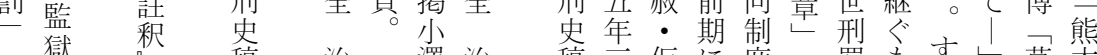
五問稿治澤治稿三仮に度一罰も西し草本

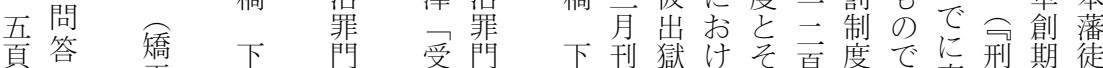
以録正占門受門年獄けそ頁度でに刑期徒 行

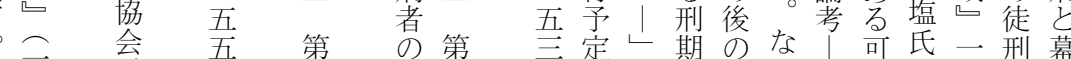

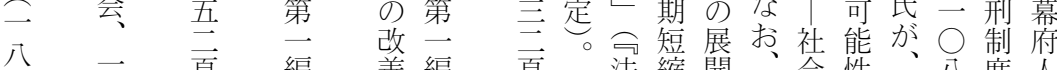
八 公頁編善編頁法縮開会性こ八度人

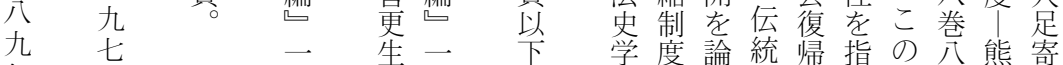

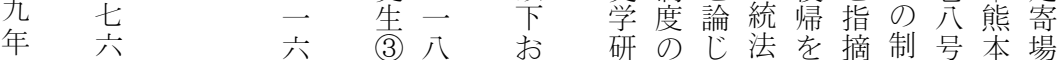

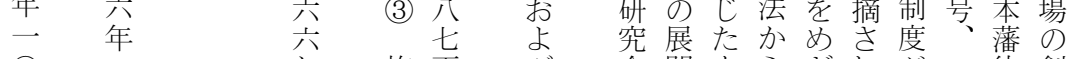

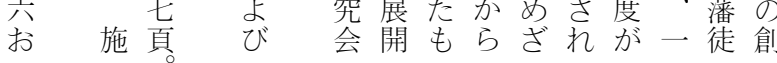

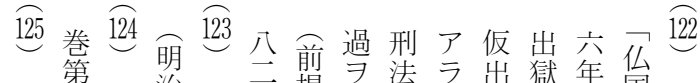

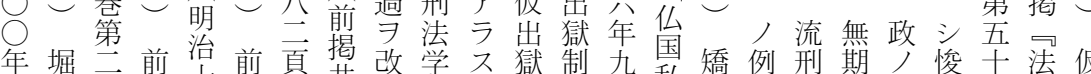
七分捍十掲貝井改学又獄制九私知例刑期人悛士法仮 月正冊磯六掲。上又者

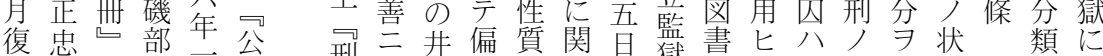

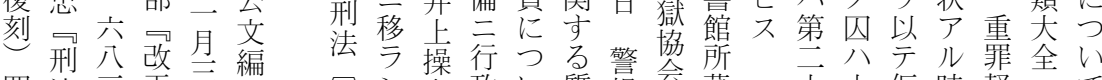

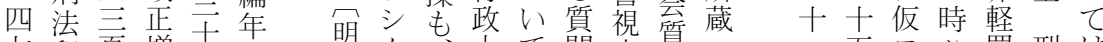

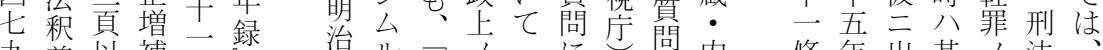

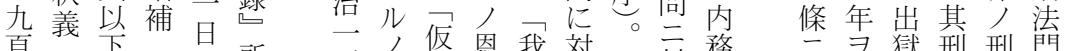
頁下所 三人仮恩我対同対務三 獄刑刑門旧

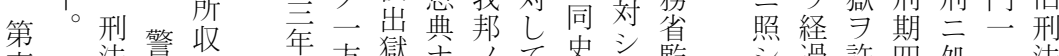
壹法警收年方獄突, て史答監㴶過許四処法 篇可視仮述法八リ仮小料答獄幽ス 分セ第に

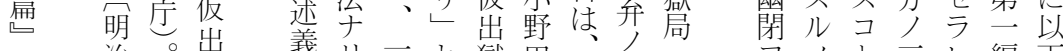

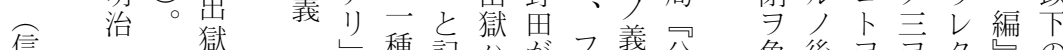

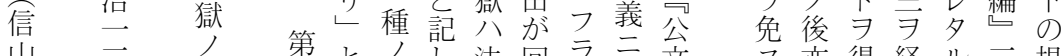

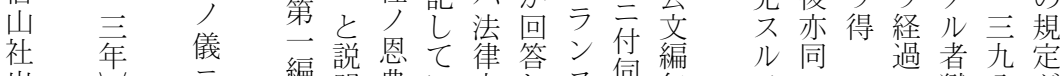

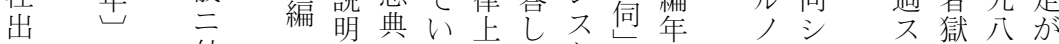
版講付 氐しるるうたが録外則頁あ 二 義上止它 


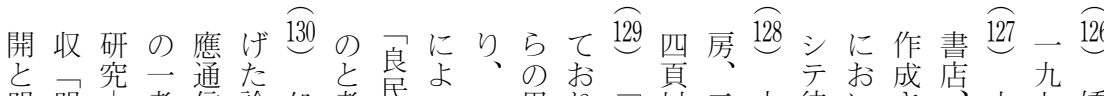

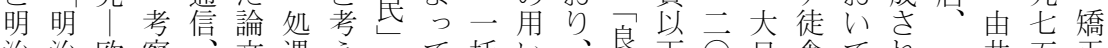
治治欧察文遇え・て括い良卡

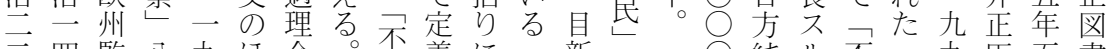
三四監八九ほ念。不義に新と○純ル不二九臣五書 年年獄七八加良さ論良しとい年夫者良戸○・层館

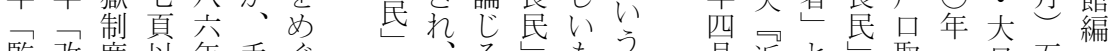
監改度以年手ぐはも方近と取一五五 獄正の六塚るは各このの言代定は調一方頁監 則監導、月豊当一個と語で葉所日義手月純。獄 一獄入前可時定人はにはそ林は収本さ其続二夫夫事

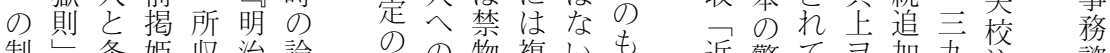
制条姫收治論意の物複いもも近警て妇艻艻注諮 定下約嶋马刑争意ラで数。の 代察い犯到注詢 に改口明法に 九拈正明治史つ 二けを治二のい 頁るめ監市研て 以監ぐ獄年究は 下 獄 つ 法 行乙成罪下注 政| 立石〔 110 のに史事こに 展所の件慶掲

味べあのまは でリる意た德 いグしが内期 らに込務か れ用七, 省 てい、 5 之用 いら内法い たれ務て学ら もた省お者れ
国とる。否頁官会

家地。ヨよ 。僚記 の域媴る。明制事 成会無おな二警矯

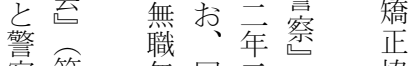
察筑 無同二協 摩産史月岩会

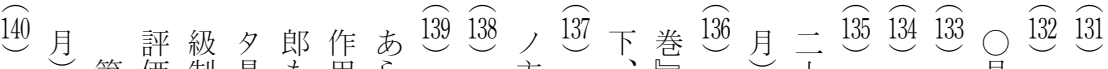
第価制是も用 5 主、卷、荺

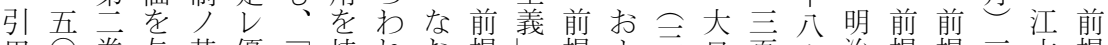
用 $\bigcirc$ 巻与基優名持れお揭揭よ三旦頁巻治揭揭三杰揭

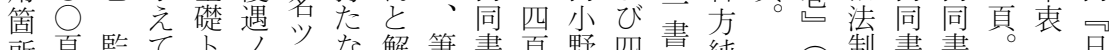

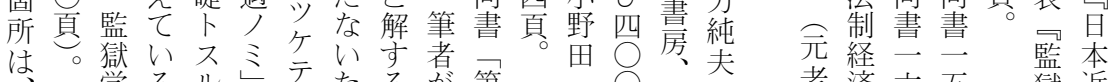
学るルヒ、賞たるが第只只一ほ老済六五獄近

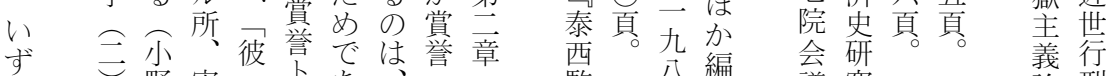

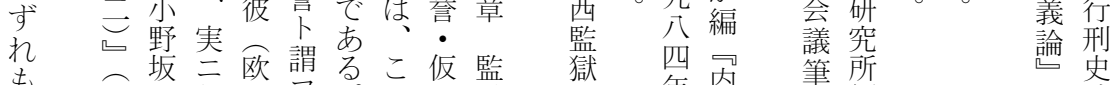

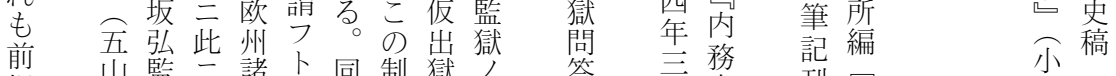

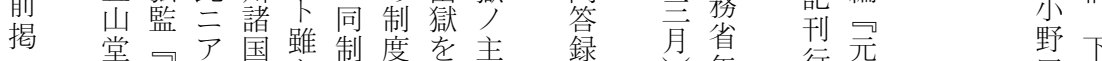

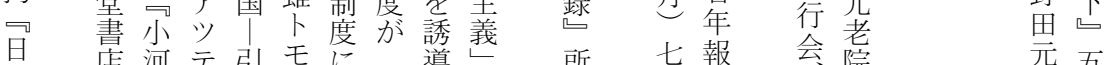
日本店河テ引モに導我所 七報会院元五

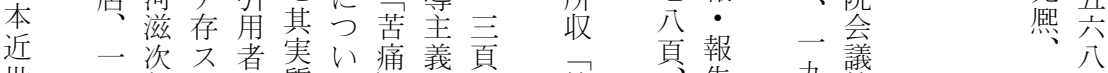

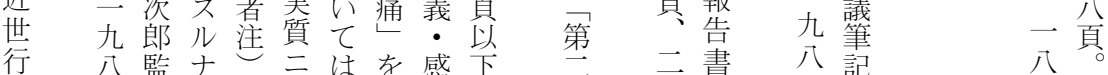
刑九獄り, 於小加化。章五朢記 史年学レ所テ河味主第年後五

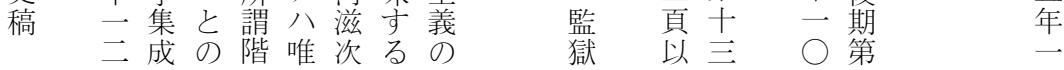




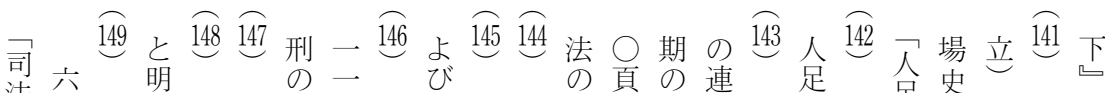
法公江治前前成公前七前前影方徒続こ寄前足史| 前五 対岩杰二掲掲立五掲三掲掲響よ刑性の場掲場創四掲六

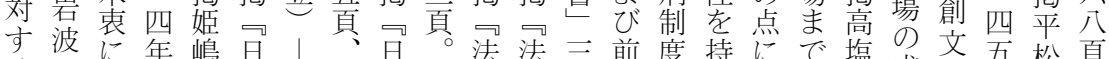
る書ら年嶋早し前本阹法三前度持にで塩成社㐬松頁 国店い改実近七掲近分分而挋熊もき—草立社お一 刑 の一は步敄的行頁松行 類類以嶋本の 四創変二び罰

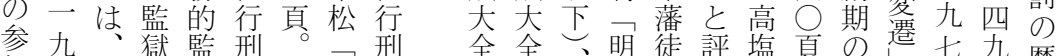
参九獄監刑。刑全全、明徒評塩頁の㟟七九歴 加六潮則獄史刑史置稿治刑飞家刑価博以徒一四頁史

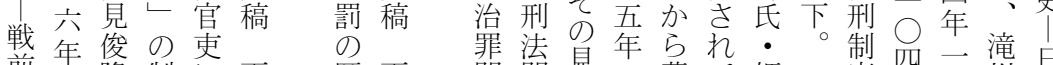

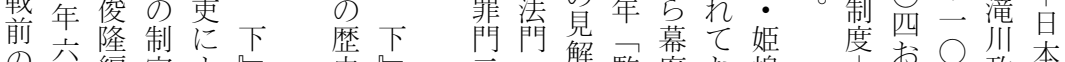

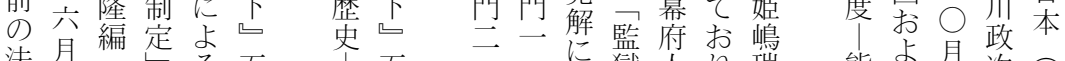

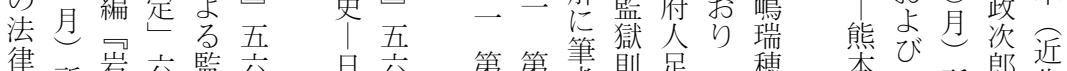

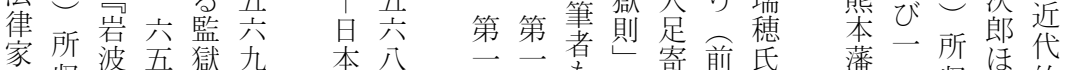

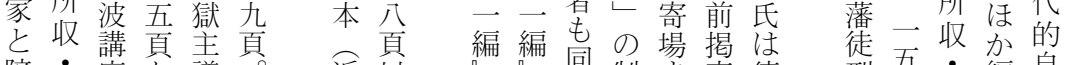

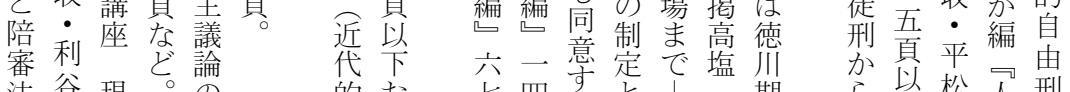

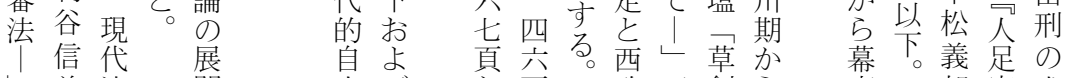
義法開宙び頁欧五創 5 府郎寄成

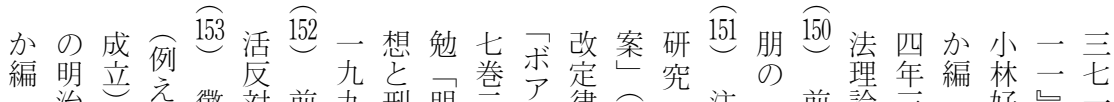

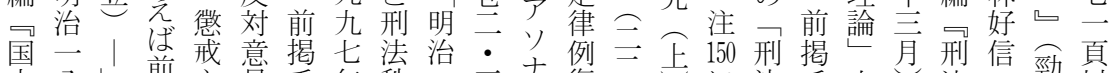

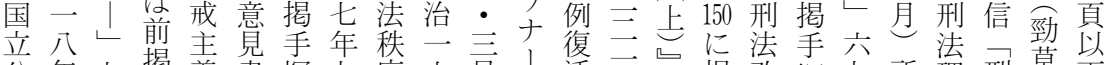

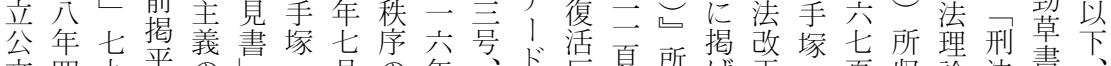

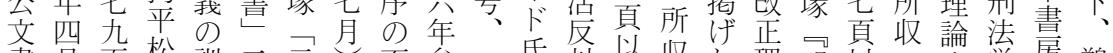

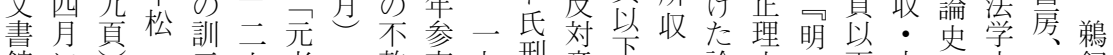
館にが刑示六老二整事九刑意巨品論由治卡木更

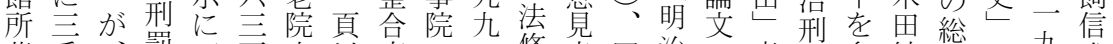
蔵重、罰石頁内以序の㘳書同治の意法参純合二九成

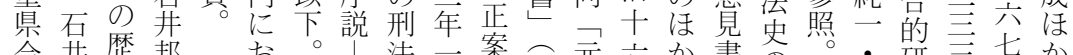

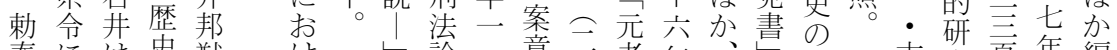
奏には史䣭比論二意亲老年、豆研吉究頁年編 任転訓|がる小見六院 - 前二究川究以五 官し示日関新 日考書二面内参掲七究経合卡講

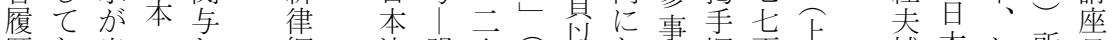

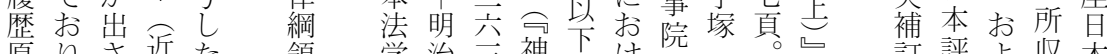

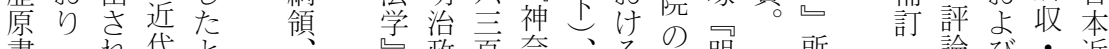
書热代と政頁奈、るの明所 論び・近 - 我る的の改六府以頁吉新刑治収江社吉佐代

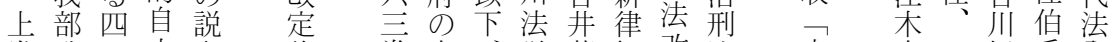
巻政加电律巻憲、学蒼綱改法山衣一経千発 男月刑あ 例 二法新生領正史県 の九夫伋達 転ほ前のる復号構井二夫圭草の有刑九ほ・史 


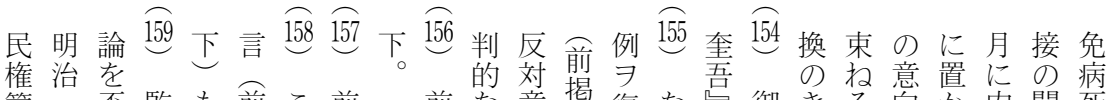
篇二否監も前こ前前な意揭復な号御きる向か内関死

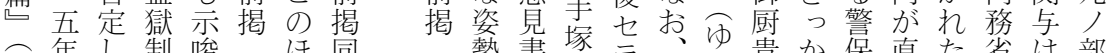

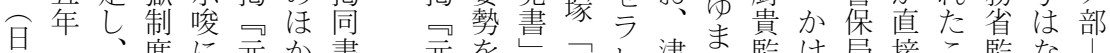
本吉社と富老か、書 元を元レ津に監け局接こ監ない

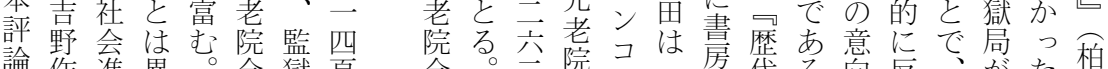

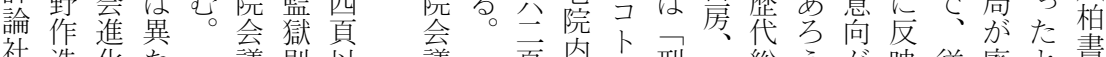
社造化な 議則以議頁内与刑一総う㤎映従廃と書 編論る 筆の市筆以に法示理。前で来止思房

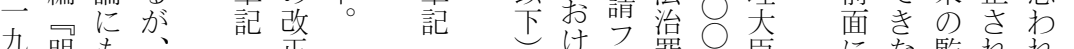
九明も止けフ罪六臣にな監れ㧫九 七治と例後自文後 な期義法年伝出く獄 る。 年化く第にと、律廃自叢きな行監む五 二集利藤吉重加 月観弘公な 所第圭点巻綿 收巻え炅五直 加自の企頁の 藤由は権以発

八法案新九第

巻改提律五一

対定出綱頁四

律者領巻

て例で改

も復あ定

批活る律
こと担政 ろ。

が警い警明 治

こ察た監の局公頁

の 政 獄も年

転を局と六直

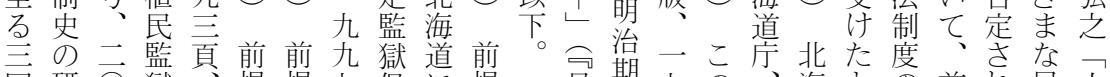
回研 $\vec{\bigcirc}$ 獄具掲掲七保に掲昌期九の 、海との前れ局人 の究 $\bigcirc$ 小 $\neg \square$ 年存設 $\neg$ 本行七点一道考一揭て面権 改に一鉱野日法三財置日法型 $\bigcirc$ 九庁え端川ゆに新 正所年山義本規月団さ本学思年つ主編るでロくお説

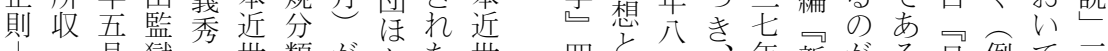
、月獄口世類がかた世四々月年新がる日例て三

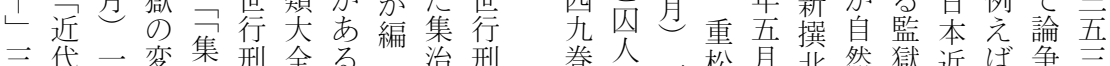

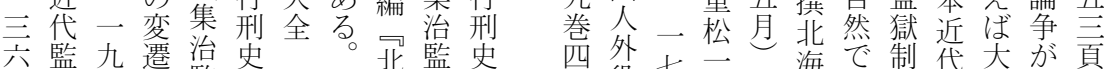

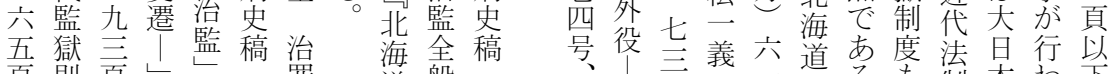
頁則頁

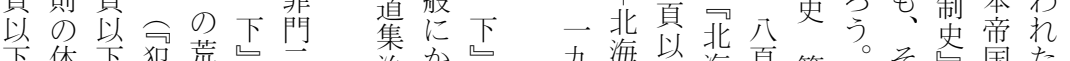
下体下犯荒々二治から海以海頁第。そ国たで な系、罪廃五一監か一公下海以首第六二憲の市

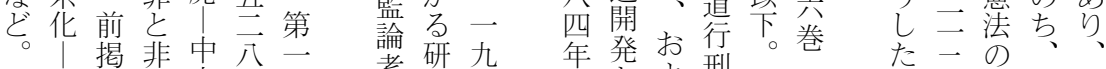
監重行央頁編考究八公とよ刑史動頁制天そ

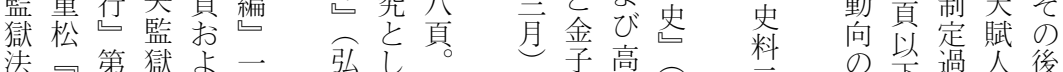

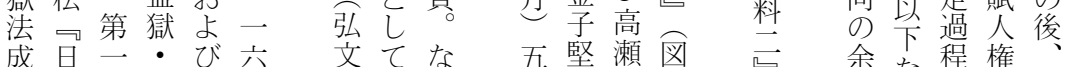

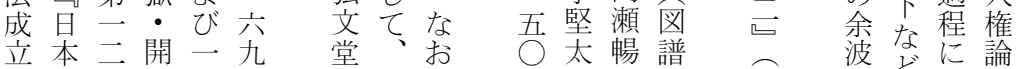

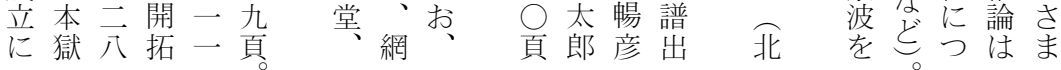




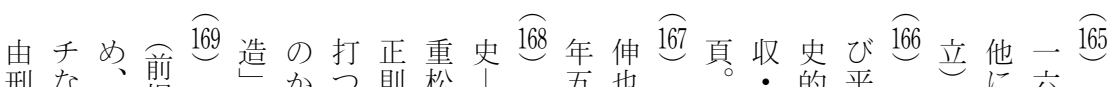
の 刑な各掲同二か? 帝|則松| 成の地可様五它国上近本の只治田察義掲上前頁掲

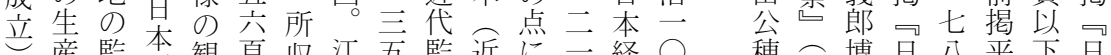
産監近観頁収江吾監近に二経 $\bigcirc$ 穂名博日公平下日 ○獄世点以一六獄代言四済年—名士本頁松、本 - 前で行架国加頁則的及員史代明层追近以一一近 七掲内行 5 家 5 刑自专以後 九平役刑々明前体由る市。近 頁松之史え資治揭系刑も。世

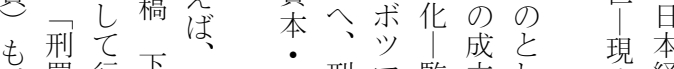

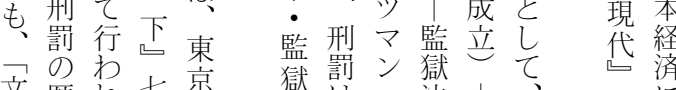
文歴れ七京獄罚ン獄、て、法| 明史た 焦七治文血成七前岩つ

・日ラ頁監 近本资以の開権れ至頁松

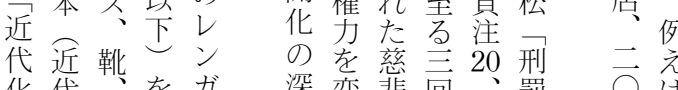
化代、をガ深変悲回、罰 ○注 的マは製層え前の一杉 と自ッじ造構た笞改掲歴二山 治屋悼世卡刑一世 期学論行も罰八行 に学文刑参 の五刑 お出集史照歴頁史 け版編稿监史以稿 る会集 刑一委下韻々本よゅ 枒九会七本よ゙— 業八編四近一一 書ての七四代一五 店、展年法頁的九五 例開一之以自夏 之云刑下、由頁以 二四罰、刑以卡、 四五所歴よ お 成

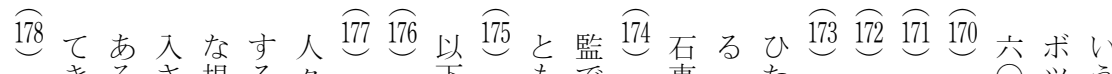

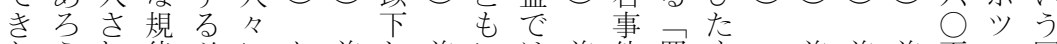
前たうれ律必にな前お前には前件罪す一前前前頁マ国 掲教。てに要そお掲よ揭同明掲の石ら部掲掲掲。ン家 平育こも馴がう、安びロ二治ロ一事施府同同口自 松なの、染あしこ丸云法分二日考件設県書書監国標

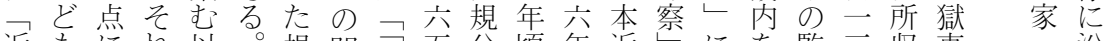
近もにれ以。規問宦五分頃年近质に監三収事・沿 代視つ 5 前一律題监頁類まか世八つ歩獄二 ・ 務資つ 自野いのに般が䟎獄。缶でら行七いかに頁佐諮本た 由にて規あ社受考の全継、刑頁てせお。方詢・作 刑、は律っ会容え誕続三史以はるい木会監業 の別今はての哥え誕治し池稿下等とて、繁記獄と

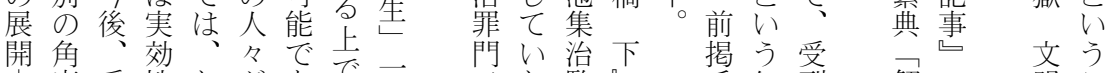
|度受性たがあで二就た監々手処刑解二 明こ

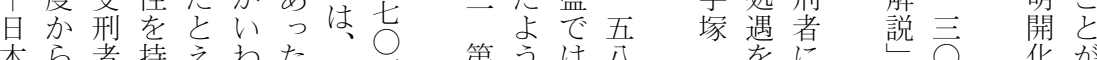
本ら者持えわたそ頁第うは八分えに化が に検のち監ゆのそ具西で同七明行石一頁ので お討年え獄るかも編あ二頁治つをを 七以深き

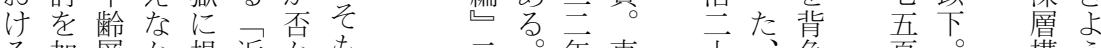

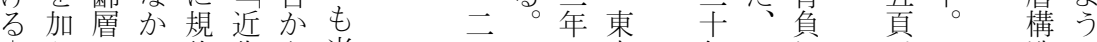

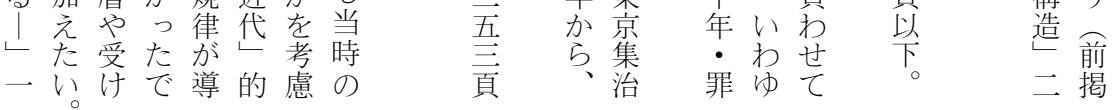




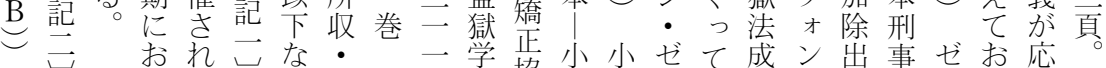

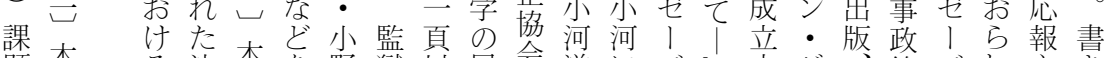
題本る法本を野獄以展会滋にバゅ史ゼ策バれ主き 䊬稿地制稿参坂学卡開、资つッ所の|- 研ッな義ぶ 号は方史は照弘へ、| 开郎い八収研バ九究八かとり

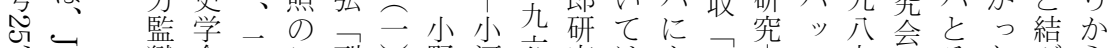

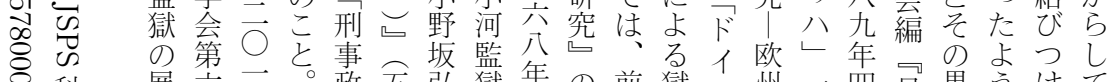
○科展六三。政五弘獄年の前獄 ツ州二四日果うけて の学開五至策山監学二ほ掲制監監八月本たにら

助研上回年家堂口と○加指獄獄五刑しもれ平 成究を総六々書小正月、野導学制頁所事た読た松

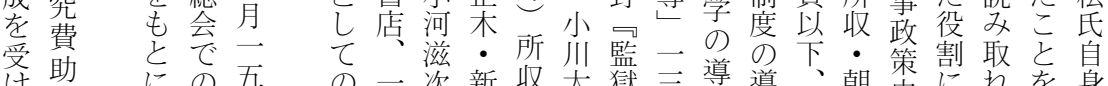
け成にの五の一次新収太獄三導導、朝史に机を身 た成作口旦 小九郎監 胡郎行二入前令上つる。自も の業成頭に法河八監獄朝編政頁と学倉官揭京のい然徵 で若た告政次年学の京矯僚下儿約嶋口々 年流戒 あ若も手大郎一集対一正とな卜改鸟々例犯・

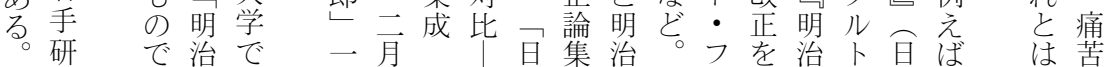
究 あ前開頁第七本昆方監・本日考主

現法置るの 入さあ各のと自関わ法ら方 場し制なよ目そとれる地一でも由于桠施自本る本 でか度どう的のていの八あな刑るる獄行由稿規稿要 は、、の、は後こいは監七る。っのル。のに刑で律は、

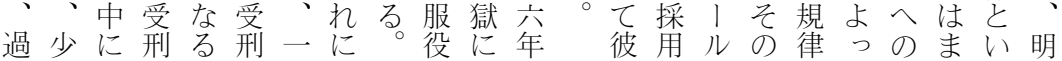
酷な組者。者八よそ態お以 なくみのそを分っの度い降をよ敩容関達全、観前 労と込内 働もん面て良年生景評、東理て化るるさ切本かに を一だに彼民に心に価受京・受さ以最れりにらお 科八の働らしなたは古刑警統刑れ前初た替お捉け す八できはにる改るる者視制者るとのこえけえる な七あか、作と革西とを庁市がと比変とがるよ監 ど年るけ規り、機洋いそやる急い方花を、死う獄 に。る律か監運のっの内必増うて、明い刑と制 肉いさへえ獄が法た習務要しも主しらずの試度 体たまのる制あ制統熟省がたの受一かれ不みの 的るざ順こ度っ度治度に生こで刑八にも可る展 苦まま応とのたに技によ学をあ者七し二視も開 痛でなにに設。関術合るたいっの言た八化のを を統応あ計守がわ主 与監治じる者る新也導 え獄技たとは知たて て行術優理、識に教も 懲政を遇解監の導育と 万 措守獄 流六し

こおた生年。公とで にびこや降年身る刑 よそれ行にの体。者 るれは動あ旧刑に 
明治前期の監獄における規律の導入と展開

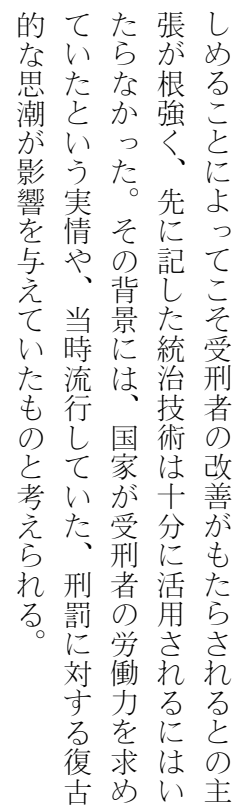




\section{Innovation and Development of Discipline in the Prison of the First Half of the Meiji Era}

\section{by Keiji KODAMA}

This paper is trying to describe the development of the prison system in the first half of the Meiji era from the perspective of discipline for inmates.

First, I have clarified that two significant changes were brought about by the enforcement of old criminal law in 1882 . One was the invisible death penalty and the other was complete switch from corporal punishment to imprisonment.

The first change of discipline in the prison appeared in and after 1873 to the effect that rules about the life and behavior of inmates became severe. This was caused by the increasing number of inmates by imprisonment, and the necessity for prison officers to manage and control them.

From 1876 onward, a new technology was introduced into local prisons. For example, individualized education of inmates and the evaluation of the attitude of inmates were both innovated by the Ministry of Home Affairs and the Metropolitan Police Department. In the background, there was an inflow of knowledge about legal systems of the West, which gave them momentum for a reform.

In and after 1882, the designer of the prison system was made to understand that the purpose of a prison is to transform inmates into "Good People". They introduced a variety of techniques into the legal system to reach out to the interior of the inmates, for example, they gave them preferential treatment in accordance with the observance of the rules.

But until 1887 at the earliest, prison officers believed that inmates 
were reformed by physical pain and punishment. So the techniques mentioned above were not put to sufficient use. One of the reasons was that the national government was expecting the labor force of inmates. Another was that a reactionary theory of punishment was in vogue at that time. 